\title{
O PROCESSSO DE INDIVIDUALIZAÇÃO DO SUJEITO NO DISCURSO PUBLICITÁRIO
}

Dissertação apresentada ao Instituto de Biociências, Letras e Ciências Exatas da Universidade Estadual Paulista, Campus de São José do Rio Preto, para obtenção do título de Mestre em Estudos Lingüísticos (Área de Concentração: Análise Lingüística)

Orientador: Prof. Dr. José Horta Nunes

São José do Rio Preto 
Silva, Walkiria Aparecida David.

O processo de individualização do sujeito no discurso publicitário / Walkiria Aparecida David Silva. - São José do Rio Preto : [s.n.], 2010.

126 f. : il. ; $30 \mathrm{~cm}$.

Orientador: José Horta Nunes

Dissertação (mestrado) - Universidade Estadual Paulista, Instituto de Biociências, Letras e Ciências Exatas

1. Análise de discurso. 2. Publicidade. 3. Subjetividade. I. Nunes, José Horta. II. Universidade Estadual Paulista, Instituto de Biociências, Letras e Ciências Exatas. III. Título.

$$
\text { CDU }-81^{\prime} 42
$$

Ficha catalográfica elaborada pela Biblioteca do IBILCE Campus de São José do Rio Preto - UNESP 
COMISSÃO JULGADORA

\title{
Titulares
}

Prof. Dr. José Horta Nunes - Orientador

UNESP - São José do Rio Preto

Prof $^{\mathrm{a}}$. Dr ${ }^{\mathrm{a}}$. Cristiane Dias

UNICAMP - Campinas

Prof $^{\mathrm{a}}$. Dr ${ }^{\mathrm{a}}$. Maria Onice Payer

UNIVAS - Pouso Alegre

\section{Suplentes}

\author{
Prof $^{a}$. Dra . Cláudia C. Pfeiffer \\ UNICAMP - Campinas \\ Prof $^{\mathrm{a}}$. Dr ${ }^{\mathrm{a}}$. Fabiana Komesu \\ UNESP - São José do Rio Preto
}




\section{AGRADECIMENTOS}

Agradeço primeiramente a Deus, pela vida.

À meus pais, pelo apoio e pela oportunidade de estudo.

Ao meu orientador, José Horta, pela confiança e por me "emprestar" seu conhecimento.

À professora Carolina Rodríguez, da UNICAMP, pelos comentários feitos por ocasião do SELIN de 2009.

À Cristiane Dias e Cláudia Pfeiffer, docentes da UNICAMP, pela leitura atenta de meu trabalho, bem como pelas contribuições valiosíssimas durante o Exame de Qualificação.

À Maria Onice Payer, por suas preciosas observações feitas durante a defesa.

Aos colegas do PALADIS, pelas discussões que me proporcionaram aperfeiçoar o conhecimento e me aprofundar na Análise de Discurso. 
A meus pais, Reinaldo e Juceli

Pelo amor e pelo carinho incondicionais,

Por acreditarem em mim,

E por me ensinarem o que não está nos livros. 
"Clama a mim, e responder-te-ei e anunciar-te-ei coisas grandes e firmes, que não sabes".

Jeremias $33: 3$ 


\section{SUMÁRIO}

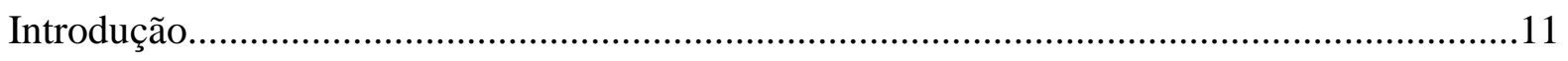

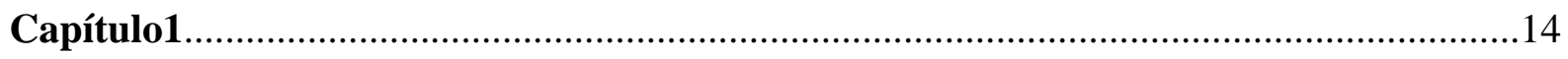

O discurso publicitário e a individualização do sujeito

Capítulo2 .28

Considerações teóricas e metodológicas

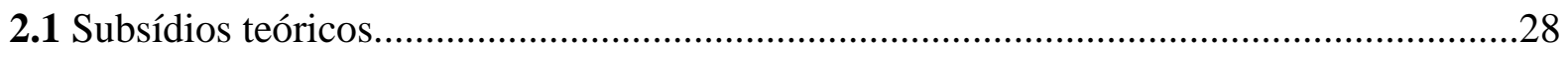

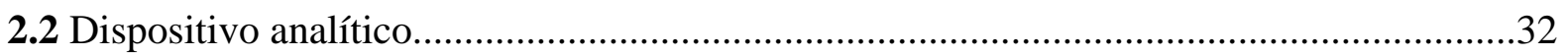

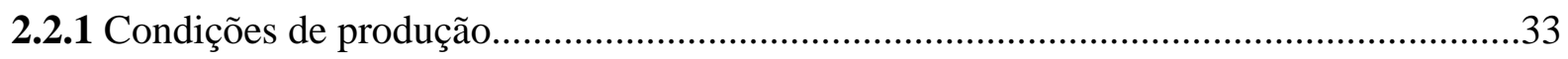

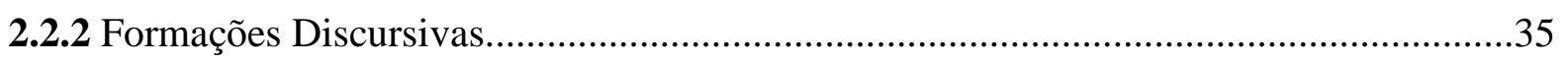

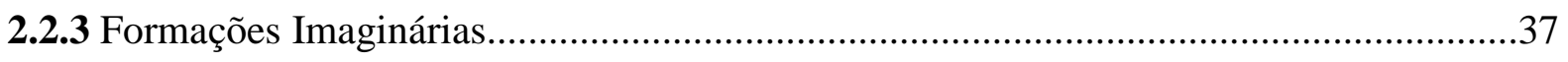

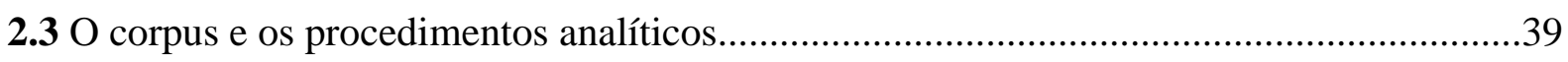

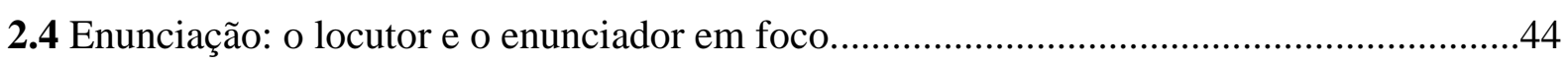

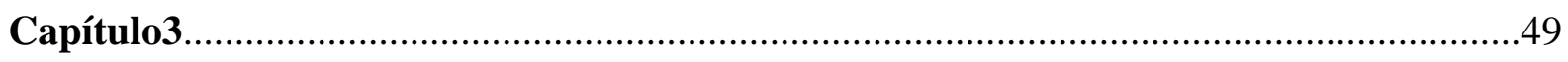

Análise das séries

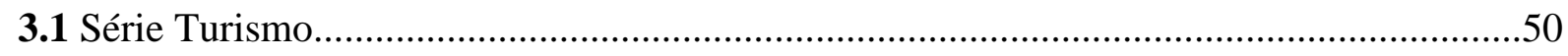

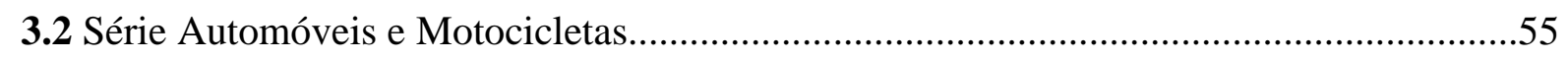

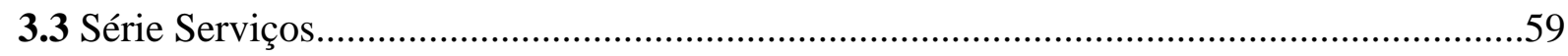

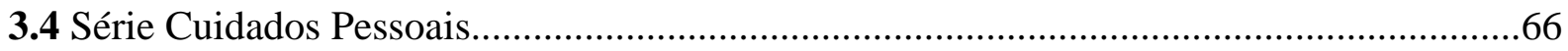

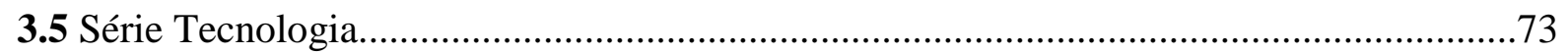

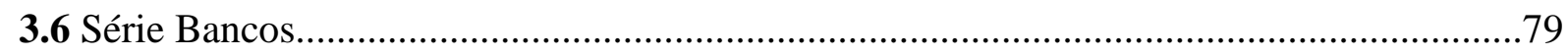

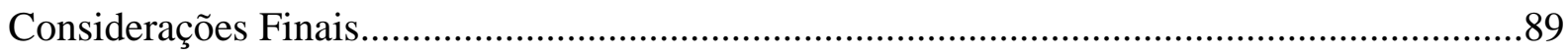

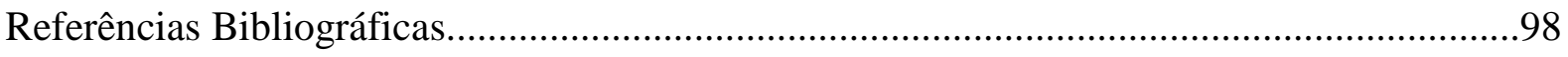

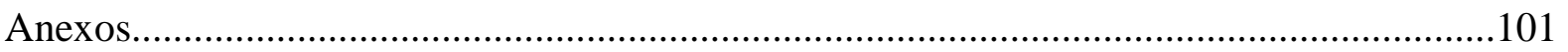




\section{RESUMO}

Esta dissertação apresenta uma análise do processo de individualização do sujeito no discurso publicitário a partir da perspectiva teórica da Análise de Discurso. Nosso corpus constitui-se de algumas páginas publicitárias da Revista Veja do período de Maio a Julho de 2008. A partir dessas propagandas procuramos depreender as regularidades do funcionamento do discurso propagandístico, bem como delimitar as marcas lingüísticas e nãolinguísticas do processo de individualização do sujeito presentes no discurso em questão. A publicidade exerce papel fundamental na sociedade contemporânea, explicitando a relação do sujeito com o conjunto social, em determinada conjuntura histórica. O texto publicitário influencia a constituição de sentidos junto aos leitores, interpelando os mesmos enquanto sujeitos. O discurso publicitário tem um funcionamento que lhe é próprio e que, portanto, lhe dá especificidade. Assim sendo, esse discurso se particulariza, remetendo-nos às formações imaginárias e ideológicas ali presentes. Baseando-se na relação linguagem e contexto, a Análise de Discurso busca explicitar como, em seu funcionamento, o texto produz sentidos, sempre observando as condições de produção. Visa-se, ainda, à compreensão da historicidade dos sentidos e dos sujeitos. No que se refere às regularidades encontradas no funcionamento do discurso propagandístico, percebemos a relação estabelecida entre o sonho, o desejo e a ideologia; a sustentação dos dizeres dos anúncios pela forma-sujeito histórica da atualidade; o atravessamento (tanto no verbal quanto no não-verbal) do discurso publicitário por outros discursos como o ecológico, sobre a beleza, sobre a mulher, da globalização. Quanto às marcas lingüísticas da individualização, apontamos a pronominalização (seu, sua), que individualiza por marcar um certo tipo de abordagem junto ao leitor; a adjetivação (exclusivo, personalizado) que faz referência ao "você" identificado com o leitor da propaganda; o modo imperativo do verbo, que instaura uma identificação entre o dizer e o fazer. Na enunciação, salientamos a coletivização, que marca a posição da empresa anunciante como grupo 
organizado, designado por "a gente" ou "nós"; e a individualização que se refere ao interlocutor da propaganda nomeado por "você", ressaltando uma característica do texto propagandístico de dirigir-se a todos e a cada um ao mesmo tempo.

Palavras-chave: Análise de Discurso, publicidade, interpelação ideológica, individualização do sujeito. 


\begin{abstract}
This dissertation presents an analysis of the individualization process in the advertising discourse, based on the theoretical perspective of Discourse Analysis. The corpus consists of some advertising pages of Veja Magazine from May to July of 2008. Based on the advertisings, this research looked for describe some regularities of advertising discourse working, as well as set out some linguistic and non-linguistic marks of the individualization process in this discourse. Advertising plays a fundamental role in the contemporary society, expliciting the relation between subject and the social set, in certain historical period. Advertising texts influence the construction of meanings, interpellating readers. Advertising discourse has a proper working that particularizes it. So, this discourse is very specific, and reveal the imaginary and ideological formations. Based on the relation between language and context, Analysis Discourse points out, how in its working, text creates some meanings, always observing the production conditions. The aim, even, is to understand the historicity of subjects and meanings. Regarding to the regularities that were found in the advertising discourse there are the relation among dream, desire and ideology; statements of advertising are supported by the historical form-subject; the "crossing" of advertisings by other discourses like environmental, about beauty, about women and globalization discourse. Referring to the linguistic marks of individualization process, there are the pronominalization (your) which individualizes due to a certain kind of reader's approach; the use of some adjectives (exclusive, personalized) which refers to the reader named as "you"; imperative mood that establishes identification between to say and to do. In the enunciation, there are collectivization the shows the company's position as an organized group, named by "we"; and the individualization, which refers to the advertising readers, always named by "you", highlighting one peculiarity of advertising text that is to address to everyboby and to each people at the same time.
\end{abstract}


Keywords: Discourse Analysis, advertising, ideological interpellation, individualization. 


\section{INTRODUÇÃO}

Esta pesquisa objetiva analisar, a partir da perspectiva teórica da Análise de Discurso (AD), as páginas publicitárias da Revista Veja, considerando tanto as marcas verbais quanto as não-verbais do processo de individualização do sujeito, visando compreender as marcas deste processo na materialidade do discurso.

Escolhemos a Veja por se tratar de uma revista tradicional em nosso país, com grande circulação nacional. Outro fato que contribuiu para a escolha da publicação foi a quantidade e variedade de produtos anunciados nas páginas publicitárias (carros, serviços, eletroeletrônicos, turismo, dentre outros).

Como temos observado, a Veja vem apresentando um número crescente de páginas publicitárias. Tal fato nos ajudou a compreender a imagem que a revista e os anunciantes ali presentes têm do leitor, um leitor virtual que está presente nos anúncios, e que pode não corresponder ao real leitor da revista. Assim, podemos pensar tanto no lugar da propaganda no discurso da Veja, quanto na interpelação do sujeito-leitor.

A Análise de Discurso de linha francesa, perspectiva teórica que embasa nossa pesquisa, questiona a evidência dos sentidos e vê na ideologia um mecanismo de produção de evidência dos mesmos. Para esta disciplina, "não há uma verdade oculta atrás do texto" (Orlandi, 2001, p. 26), mas há gestos de interpretação que determinam a produção de sentidos. São estes gestos de interpretação que o analista de discurso deve procurar compreender. Nossos objetivos são, portanto, compreender o funcionamento do discurso publicitário, buscando nele as marcas do processo de individualização do sujeito na contemporaneidade.

O que nos levou a estudar a individualização foi o fato de ser esta uma questão importante e atual para a AD. A individualização tem sido objeto de estudo de várias pesquisas em Análise de Discurso, visto que este processo é fundamental para o entendimento 
de como se dá a constituição do sujeito na contemporaneidade. Já trabalhamos com as páginas publicitárias da Veja na Iniciação Científica, e optamos por continuar com estes textos na pesquisa de mestrado. Quando da seleção do corpus, notamos as marcas da individualização do sujeito, e então decidimos analisar como se dá este processo no discurso publicitário. Visamos, pois, com este estudo, contribuir com as pesquisas sobre o processo de individualização do sujeito neste campo de saber.

Esta pesquisa está estruturada em três capítulos, além da introdução e das considerações finais do trabalho.

No primeiro capítulo, fizemos uma explanação tanto sobre o funcionamento discursivo publicitário quanto sobre o processo de individualização do sujeito neste discurso. Procuramos, nesta parte do texto, relacionar o discurso estudado com o complexo social em que está inserido. Sendo assim, nos detivemos em cinco questões principais, quais sejam: o discurso publicitário e algumas transformações históricas que culminaram na atual conjuntura; as condições sócio-históricas de produção do discurso publicitário; a textualidade e as propriedades deste discurso; a interpelação ideológica, em especial a individualização; a relação do sujeito com o simbólico.

No capítulo seguinte, nos debruçamos sobre a teoria e o método da Análise de Discurso, evidenciando o alcance teórico da disciplina, suas filiações teóricas e os conceitos mobilizados em nosso percurso de análise. Trabalhamos aqui com o dispositivo teórico da interpretação e com o dispositivo analítico, como formulado por Orlandi (2001).

No terceiro capítulo, nos dedicamos à analise do corpus, orientada pela teoria e pelo método discutidos no capítulo anterior. É nesta parte da dissertação que distribuímos nossos textos de análise em séries temáticas, que serão analisadas, num primeiro momento separadamente, e depois, relacionando-as entre si, mostrando-se as regularidades do discurso publicitário e também as marcas verbais e não-verbais do processo de individualização do 
sujeito. Neste capítulo também explicitarei como a revista Veja faz parte das condições de produção dos textos analisados.

Nas considerações finais, retomaremos os objetivos de pesquisa e mostraremos as conclusões a que pudemos chegar nesta pesquisa de mestrado.

Concluído o trabalho e alcançados os objetivos propostos, sempre pensando em nossos interlocutores, teremos um texto que não somente é de interesse para a Análise de Discurso, mas também para as áreas de publicidade e de comunicação, dentre outras. 


\section{O DISCURSO PUBLICITÁRIO E A INDIVIDUALIZAÇÃo DO SUJEITO}

Neste capítulo, abordaremos como a publicidade é vista na perspectiva da AD, considerando-se a conjuntura sócio-histórica em que tal discurso é produzido. Nosso objetivo, nesta parte, não é fazer um percurso histórico do discurso publicitário, mas ver seu funcionamento na sociedade atual, relacionando-o às condições de produção de tal discurso. Mais adiante, no mesmo capítulo, discutiremos o processo de individualização do sujeito como o teoriza Eni Orlandi em muitos de seus recentes trabalhos.

No mundo contemporâneo, no qual estão presentes as mais diversas linguagens, o discurso publicitário se destaca por nos dar indícios do funcionamento e do imaginário da sociedade em que está inserido. È neste discurso que procuramos compreender o processo de individualização do sujeito, objeto desta pesquisa.

Historicamente, não é nova a preocupação de se chegar ao público consumidor. No entanto, as ideologias publicitárias foram variando paulatinamente, em consonância com as modificações ocorridas nos diversos setores da esfera social, quais sejam as mudanças oriundas do capitalismo, do setor industrial, bem como as novas formas de consumo. Se pensarmos o passado e o presente no que se refere à feitura dos anúncios, perceberemos que antigamente eles eram rudimentares, e hoje esbanjam sofisticação e se apropriam de novas tecnologias. Pensamos que isso se deve ao fato de o discurso do consumo, tão presente na sociedade atual, ter levado a imagem à primazia.

Ressaltamos que com tantas transformações sociais houve também mutações na subjetividade. Falando sobre a sociedade atual, Rolnik (1995, p. 49) esclarece que “qualquer mudança efetiva do campo social hoje, depende de uma mutação na subjetividade na base da qual funciona a sociedade em que vivemos". Compreendemos o subjetivo não 
como o que afeta o sujeito, mas como o que interfere em sua constituição. Discorrendo sobre o sujeito na história e no simbólico, Orlandi (2008, p.99) afirma que "a subjetividade pode interessar, discursivamente, pelo fato de que ela permite compreender como a língua acontece no homem". Em se tratando do discurso publicitário, trabalhamos com a não-totalidade do sujeito, com o sujeito faltante, desejante, sendo este histórico e, como tal, passível de sofrer alterações no processo de produção de sua subjetividade. O consumismo seria uma das formas de suprir esta falta, esta lacuna do sujeito.

Relacionando o consumismo, a sociedade e os sujeitos contemporâneos, tal qual compreendidos nesta pesquisa, concordamos com as afirmações do sociólogo Bauman (1998, p. 56) quando este afirma que

Se o consumo é a medida de uma vida bem sucedida, da felicidade e mesmo da decência humana, então foi retirada a tampa dos desejos humanos: nenhuma quantidade de aquisições e sensações emocionantes tem qualquer probabilidade de trazer satisfação da maneira como o 'manter-se ao nível dos padrões' outrora prometeu: não há padrões a cujo nível se manter - a linha de chegada avança junto com o corredor, e as metas permanecem continuamente distantes, enquanto se tenta alcançá-las.

A partir das afirmações de Bauman, podemos pensar novamente na busca incessante desse sujeito sempre faltante, bem como no crescente consumismo, fato tão divulgado pela mídia atualmente. A esse respeito também fala o psicanalista Joel Birman (2005, p. 11), destacando que “o consumo se transformou também numa compulsão, de maneira que o Shopping Center é um outro santuário do mundo pós-moderno”. Sobre este tema, citamos ainda Hansen (2009, p. 179), que fala sobre o sujeito desejante da mesma perspectiva teórica à qual nos filiamos:

Na perspectiva da $\mathrm{AD}$, referir-se ao sujeito desejante não é o mesmo que fazer menção ao desejo do sujeito. Estas duas noções não podem se confundir, pois são distintas, apesar de complementares. O sujeito desejante 
é da ordem do esquecimento número um (inconsciente) e difere do desejo do sujeito, este da ordem do esquecimento número dois (pré- consciente). $\mathrm{O}$ sujeito desejante é o motor que nos move, que é marcado pela falta que lhe é constitutiva, da ordem do inatingível. Ele não pode ser aniquilado. Sempre resiste. Aniquila-se unicamente o seu desejo, representado pelas suas vontades, que se resolve, se saciam e sempre tem um efeito de preenchimento. Contudo, estas vontades - de outras demandas - voltam a se manifestar, confirmando a resistência do sujeito desejante, que nunca será preenchido, sempre estará incompleto e em falta.

Além do jornal - talvez o meio mais antigo e popular para a difusão da propaganda - os modernos meios de comunicação, como a imprensa falada e escrita, e também a internet, em muito contribuíram para que a publicidade se sofisticasse, tal qual ocorreu com toda linguagem. Sendo um fenômeno bem característico de nosso tempo e de nossa sociedade, a publicidade nos ajuda a compreender o funcionamento ideológico e social na contemporaneidade. A sociedade atual é caracterizada pelo consumismo, pelo crescente individualismo e pelo desejo de destacar-se do grupo social em que se vive, sendo bem sucedido nas mais diversas áreas. Funciona aí um discurso do sucesso (PAYER, 2005). Em nossos dias, é preciso fazer-se por si, prescindindo do outro. Há mais interesses individuais do que interesses comuns, evidenciando, assim, uma sociedade individualista. Segundo Orlandi (2007, p. 16),

esse consumo não é tanto aquele de produtos manufaturados mas de produtos culturais que modelizam nossas personalidades. Participar dessa sociedade em construção tem assim a ver com a participação do fluxo de intercâmbio de informações, dos sinais de pertencimento. Decorre disso um desenvolvimento do individualismo, a título de dever ser considerado. É preciso fazer o próprio lugar para ser reconhecido, tornar-se vendedor da própria vida.

Como nosso objetivo é analisar o processo de individualização do sujeito no discurso publicitário, faz-se necessário ressaltar a relação entre o texto e o discurso. $\mathrm{Na}$ 
perspectiva discursiva, o objeto de estudo é o discurso, enquanto prática de linguagem que implica o social, o histórico, o simbólico e o ideológico. Para a AD, então, "a materialidade específica da ideologia é o discurso e a materialidade específica do discurso é a língua" (ORLANDI, 2001, p. 17). Assim sendo, é a lingua que viabiliza a produção do discurso. É na língua, mais especificamente no texto, que o analista busca as marcas lingüísticas, as regularidades do funcionamento de determinado discurso. De nossa parte, partindo do texto, focalizamos o funcionamento do discurso publicitário, pois é nele que buscamos as marcas lingüísticas e não-lingüísticas do processo de individualização do sujeito. Acrescenta Mariani (2007, p. 69) que os "pontos de falha na língua, de equivocação, de deslizamento, de deslocamento, lugares que provocam o chiste, a surpresa, o inesperado, enfim, que provocam um estranhamento do dizer em relação ao próprio dizer [...]"

No processo criativo da propaganda, os publicitários trabalham com a materialidade do anúncio, valendo-se dos deslizamentos de sentido para jogar com o equívoco, provocando efeitos diversos, como os mencionados por Mariani. Este trabalho com o simbólico visa chamar a atenção do leitor para o texto publicitário, tendo como pressuposto que cada leitor (virtual) é um possível consumidor daquele produto ou serviço que está sendo ali anunciado. Ademais, as empresas buscam diferenciar-se no próprio anúncio, já que, como sabemos, num mundo onde há tantos produtos não basta ser mais um no mercado, mas há que se ter um diferencial que agrade, ou pelo menos desperte a curiosidade do leitor.

Ao folhearmos uma revista ou um jornal ou ainda quando observamos outdoors e cartazes nas ruas, nos deparamos com textos publicitários, sejam eles comerciais ou institucionais, que disputam a atenção do leitor a fim de que se possa divulgar um produto, uma idéia ou simplesmente conscientizar as pessoas acerca de um determinado assunto. Quanto à materialidade do anúncio, esclarece Ferreira (2007, p. 198) que 
Os textos publicitários, as propagandas, que circulam em revistas, são, em geral, facilmente reconhecíveis pelas especificidades de seu gênero, pelos elementos de sua construção composicional como a dimensão, o tipo de diagramação, o tipo de caractere e por seu estilo verbal e conteúdo temático, cujo objetivo principal é o de promover a venda de um produto ou de um serviço. Sua filiação a uma tradição publicitária faz dele um texto em que deve vigorar a lei do menor esforço na sua apreensão, daí a necessidade de se valer de uma ilustração o mais sugestiva possível, seja do produto, ou do serviço, seja de um conceito, de um estilo de vida relacionado a esse produto ou serviço. A imagem fotográfica é a modalidade mais comum na ilustração desse tipo de texto, por sua proximidade com o referente e, também por essa razão, por sua capacidade de promover processos de identificação.

O discurso publicitário ${ }^{1}$, como todo discurso, constitui-se numa prática, inserida em determinado conjunto social, em dada conjuntura histórica. O discurso como prática tem ação transformadora, pois é um trabalho simbólico entre o homem e sua realidade social, entendendo simbólico como as múltiplas formas de significação, de expressão e de saberes. Em nossos dias, tal discurso é tido como fundamental nesta sociedade de consumo, da qual todos, de uma maneira ou de outra, fazemos parte. Acrescenta Payer (2005, p. 16), que "além disso, a mídia se acena no cenário contemporâneo como forma textual onipresente, tanto no espaço público como no privado. Onde produz [...]efeitos de evidência dos sentidos, e portanto, efeitos de evidência do real". Nesse contexto, pode-se afirmar que os textos propagandísticos podem ser poderosas armas de uma guerra ideológica, na qual o Mercado, representante máximo do capitalismo, sai sempre vencedor. Pêcheux (apud ORLANDI, 2009b), aponta que a guerra ideológica diz respeito "às diversas operações midiáticas de massa desenvolvidas pela grande burguesia multinacional para tudo o que resiste à sua política”. Em nosso caso, as “operações midiáticas” se referem ao incentivo ao consumo que a propaganda produz.

\footnotetext{
${ }^{1}$ Nesta pesquisa, tomamos discurso publicitário e discurso da propaganda (ou propagandístico) como sinônimos. Consideramos mídia como fenômeno mais abrangente, portanto, publicidade e propaganda estão inseridos no espaço da mídia.
} 
Pensando na relação entre o sujeito e a sociedade, na constituição do sujeito contemporâneo e focalizando certas especificidades do funcionamento da linguagem na sociedade atual, entendemos que o discurso da propaganda circula socialmente seja reforçando os valores sociais já existentes, seja deslocando os mesmos, na tentativa de produzir valores mais condizentes com as necessidades do Mercado. É importante ressaltar que o discurso estudado integra um discurso social, que, por sua vez, interfere na formação e perpetuação de imagens, identidades, valores e construções ideológicas, dentro de um complexo de formações imaginárias. Trabalhando detalhadamente as possibilidades simbólicas e imaginárias da linguagem, o texto propagandístico apresenta arranjos verbais e imagéticos que interpelam - cada um a seu modo - e individualizam o sujeito-leitor. Não se trata, portanto, de enganação, de "sedução" ou de manipulação dos sentidos, mas do próprio funcionamento deste discurso, que interpela os leitores, os consumidores da propaganda. Em busca de consumidores em potencial, os textos publicitários direcionam os valores e trabalham com o imaginário, interpelando os indivíduos em sujeitos. Nunes (1998, p. 40), no entanto, esclarece que

Longe de servir apenas à venda do produto, da marca comercial ou de se constituir em um discurso "enganador", o discurso da propaganda coloca em questão agentes sociais concretos: indústrias, empresas, instituições públicas, cidadãos. Por outro lado, esse discurso trabalha de forma atenta as possibilidades simbólicas e imaginárias da linguagem. E isso dentro de um contexto social real, e não somente dentro de um contexto de ficção ou de simulação.

Nesse contexto, pode-se afirmar que a publicidade exerce papel fundamental nessa sociedade de Mercado. Nela, tudo é substituído muito depressa (fato que se relaciona com as mudanças na produção industrial, e com as novas formas de consumo), havendo assim, uma constante renovação da moda, dos estilos, e dos padrões. Lewkowics (2006, p. 27), ressalta que, indubitavelmente, “flexibilidade e re-invenção prosperam como virtudes em 
tempos de velocidade, isto é, quando as condições variam de ocasião para ocasião". Com efeito, flexibilidade e re-invenção são noções primordiais em tempos de Mercado, marcados pela velocidade das transformações e pela subjetividade consumidora. O propalado consumismo que marca nossos dias está relacionado às mudanças ocorridas em vários setores da esfera social.

Para se adaptar a essa constante renovação - e isso implica uma identificação com o grupo social em que se vive - o sujeito, cada vez mais, é impelido a consumir. Segundo Lewkowics (2006, p. 17) “a subjetividade dominante não é institucional, mas massmidiática. Neste sentido, suas operações básicas não são disciplinares. Não se trata de norma e saber, mas de imagem e opinião pessoal". Isso equivale a dizer que o Estado e suas instituições enfraqueceram-se como produtores de sentido e de subjetividades. Com o enfraquecimento do Estado, o Mercado tornou-se a instituição dominante no funcionamento social. A passagem da predominância do Mercado sobre o Estado trouxe também outro tipo de texto e, assim, outros modos de interpelação. Nesse contexto, Mariani (2009, p. 49) relaciona os estudos do filósofo Dufour, dos psicanalistas Lebrun e Melman e da analista de discurso Maria Onice Payer e considera que todos esses autores, em síntese,

apontam para uma onipresença e onipotência do Mercado como instância máxima de Poder frente aos Estados Nacionais. O que rege a maioria das relações sociais na atualidade é uma submissão à circulação da Mercadoria, uma circulação volátil e em movimento rápido e constante. Do ponto de vista político e econômico, são os efeitos desse novo capitalismo, ou seja, são os efeitos do neoliberalismo que estão afetando a função simbólica, nosso estar-no-mundo e, em conseqüência, a própria constituição do sujeito.

Falando do Estado que funcionava como forte articulador simbólico, bem como da interpelação ideológica, Claudine Haroche (1992, p. 21), postula que 
o poder, o Estado, o direito, coagem o sujeito, insinuam-se nele de forma discreta; todos tornam-se claros processos que derivam de uma técnica particular de poder que Foucault, em um dos últimos textos, designa como sendo de 'governo pela individualização'. Uma forma de poder que classifica os indivíduos em categorias, identifica-os, amarra-os, aprisiona-os em sua identidade. Aprisionamento na identidade que é obrigatoriamente exibido por cada um...

Podemos estender a afirmação de Haroche para o discurso publicitário, que coage discretamente o sujeito-leitor, "insinua-se" para ele, interpelando-o ideologicamente, individualizando-o, agindo na subjetividade e no processo de identificação entre o sujeito e o texto. Individualizado, pois, o sujeito pode-se identificar-se.

Maria Onice Payer (2005), considera que a mídia é "o grande texto da atualidade", sendo que o mesmo vem adquirindo "o valor de Texto fundamental na sociedade contemporânea", com enorme influência nos processos de produção de sentidos e também nos modos de interpelação dos sujeitos. No mesmo texto (2005, p. 17), a autora discorre ainda sobre “os enunciados que funcionam como máximas nas diversas Instituições, enquanto enunciados que têm o poder de 'interpelar os indivíduos em sujeitos'.” Pensando no Mercado como uma instituição produtora de sentido, podemos dizer que os enunciados da mídia funcionam como máximas para o sujeito contemporâneo. Neste contexto, Payer (Idem, p. 18) questiona

E na ordem do Mercado, qual seria o enunciado que vem funcionando como esse poder de interpelar ideologicamente o indivíduo em sujeito (Althusser); de imprimir a evidência do sentido (Pêcheux); de fazer crer nos enunciados até o ponto do indivíduo se conduzir segundo essa crença (Maingueneau)?

Pelo que se vem observando, o enunciado todo-poderoso do Mercado, que funciona como lugar máximo de interpelação, pode ser resumido em uma palavra: "sucesso".

O enunciado do sucesso se imprime através de inúmeros textos, e circula de muitos modos, mas sobretudo através da Mídia. Pode-se notar que há um certo "discurso do sucesso" funcionando atualmente em grande escala. 
Aceitando as colocações de Payer, e sendo a Análise de Discurso uma disciplina interpretativa, coube-nos analisar como se dá a interpelação, mais especificamente, a individualização do sujeito no discurso publicitário. Segundo Orlandi (2008, p.106), a individualização produz efeitos diversos nos processos de identificação dos sujeitos, bem como nos processos de produção de sentidos. A autora (2006c) considera que "o sujeito não é origem de si, não tem o domínio de como os sentidos se formam nele, de como ele experimenta os sentidos".

Para teorizar sobre a individualização enquanto o segundo movimento na constituição do sujeito, temos de pensar na relação do sujeito com o Estado - este Estado que funciona pela falta - e também com os sentidos. O sujeito contemporâneo, então, debate-se em controversos processos de identificação, já que, com o funcionamento do Estado pela falta, surgem novos articuladores simbólicos - como o Mercado - com o domínio ideológico do capitalismo ${ }^{2}$. O discurso publicitário, então, está inscrito na formação discursiva capitalista. O sujeito contemporâneo, foco de nossas reflexões, identifica-se, pois, com esta formação discursiva. O processo de individualização relaciona-se com essa identificação do sujeito com a formação discursiva dominante na conjuntura histórico-social em que vive - a capitalista. Abordando a relação entre o Estado e o Mercado, Orlandi (2009, p. 20-21) esclarece que

Sem negar a força do mercado contemporaneamente, a nosso ver, quando pensamos o Brasil, não diríamos que o Estado já não exerce sua função de articulador simbólico. Penso que temos de conviver com a ambigüidade produzida pela existência de sociedades de mercado e com a nossa, em que o Estado tem seu funcionamento justamente regido por sua falta e afetado pelas sociedades de mercado. Ou seja, é em sua falta que o Estado existe e exerce seu poder articulador do simbólico com o político. Em suma, o Estado funciona pela falta, produzindo o que chamamos de sem-sentido, que

\footnotetext{
${ }^{2}$ Dizer que o Estado tem seu funcionamento regido pela falta em muito difere de dizer que ele falta. No segundo caso, equivaleria a afirmar que o Estado não existe, o que não é verdade. Seu funcionamento se pauta, então, no enfraquecimento e na diluição de suas instituições.
} 
não é um vazio, mas um modo de estar na relação do político com a significação, estagnando-a no já-significado. Assim é que, a nossa posição é de que temos de compreender os novos termos de dominação, através da compreensão de como se confrontam o simbólico com o político, nesses termos.

Posta a relação existente entre o Estado e o Mercado (articuladores simbólicos e políticos, bem como produtores de subjetividade), é mister abordarmos como os sujeitos se constituem. Orlandi (2008, p. 106) esclarece que há um duplo movimento na compreensão da subjetividade, e o caracteriza no seguinte esquema (Discurso e Texto: formulação e circulação dos sentidos, 2008, p. 106):

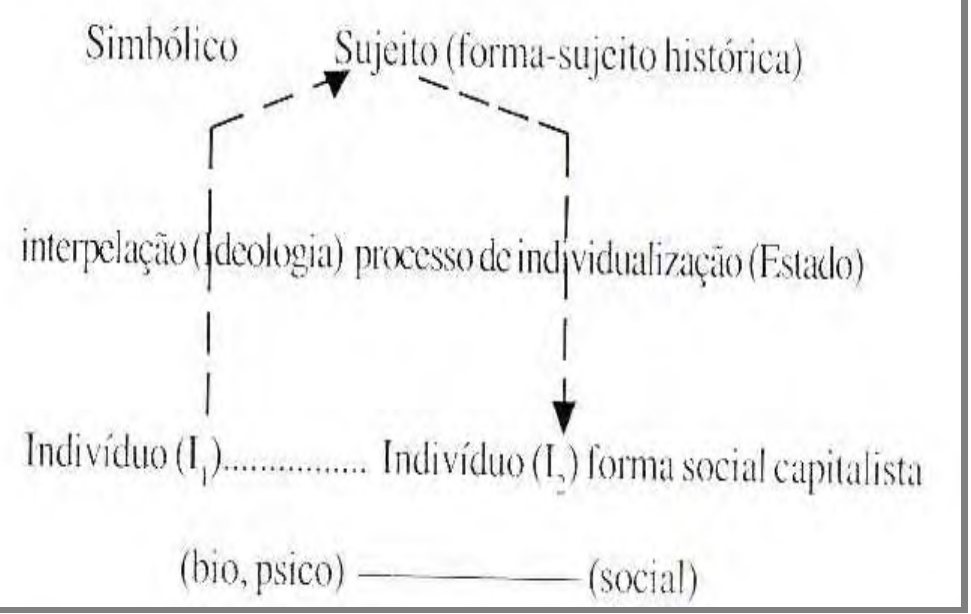

O primeiro movimento se refere à interpelação do indivíduo em sujeito pela ideologia. O indivíduo biológico e psicológico (I1), afetado pelo simbólico e inserido em dada formação histórica, é “chamado à existência”, constituindo-se como sujeito. A interpelação ideológica pressupõe um assujeitamento pela língua - já que esta se liga à ideologia pelo inconsciente - e produz a evidência da identidade. Desse primeiro movimento de subjetivação 
resulta a forma-sujeito histórica com sua materialidade específica, que Orlandi (Ibid. p. 104) assim define:

O sujeito moderno - capitalista - é ao mesmo tempo livre e submisso, determinado (pela exterioridade) e determinador (do que diz): essa é a condição de sua responsabilidade (sujeito jurídico, sujeito a direitos e deveres) e de sua coerência (não-contradição) que lhe garantem, em conjunto, sua impressão de unidade e controle de (por) sua vontade. Não só dos outros, mas de si mesmo. Bastando ter poder...

O segundo movimento na compreensão da subjetividade, indissociável do primeiro, mas dele distinto, diz respeito à individualização pelo Estado, pelas instituições a ele concernentes, e pelos discursos que circulam em determinada formação social. O processo de individualização é próprio da sociedade capitalista, pois nesta prevalecem o poder, o direito e a identificação. Os sentidos produzidos, nesses termos, resultam num certo tipo de sujeito, assim como são determinantes do modo como esses sujeitos relacionam-se com o mundo. Desta forma, podemos falar que o indivíduo "I2", é o sujeito resultante de um processo por sua relação permanente com a sociedade. Desse processo resta um sujeito ao mesmo tempo responsável e dono de sua vontade. Individualizado pelo Estado, pelas instituições e pelos discursos, o sujeito tem a ilusão de ser a origem de si, mas aí está o funcionamento ideológico, que produz a evidência de identidade para o sujeito, dando a este “sua impressão de unidade" (Id., Ibid, p. 104).

Entendemos que o lugar do discurso publicitário neste "percurso de subjetivação" está justamente na relação do sujeito com a sociedade regida pelo capitalismo, dada a importância que se dá atualmente ao discurso que estudamos (cf. Payer, 2005). Como os textos propagandísticos circulam socialmente em ampla escala, eles podem ser considerados como objetos simbólicos que afetam a constituição do sujeito contemporâneo, e em cuja materialidade ficam "pistas" do processo de individualização. Foram estas pistas que 
procuramos descrever e interpretar nesta pesquisa. Relacionando o discurso da propaganda e o processo de individualização do sujeito, Carrozza (2010, p. 12) explicita que

Um dos aspectos fundamentais do texto da publicidade é o fato de 'dizer a todos e a cada um ao mesmo tempo'. Esse mecanismo só é possível de se apreender se pensamos nesse texto em sua forma material. Não se trata, então, de olhar isoladamente para os slogans, títulos, enunciados e ilustrações de anúncios, mas sim de olhar para o texto da publicidade em seu funcionamento na história, com sua tentativa, por exemplo, de abarcar o maior número de consumidores ao mesmo tempo. Nesse sentido, a publicidade vai procurar falar a todos ao mesmo tempo ou, ao menos, a todos os 'potenciais' consumidores do produto anunciado. Ela constrói, dessa forma, um determinado tipo de leitor - um conjunto de leitores - para o anúncio. Mas não é só isso. O que pude perceber - e acredito que aí está uma pista do funcionamento do processo de individuação - é que falando a todos, ela procura também individualizar os sujeitos, como se estivesse, na sua forma de dizer, falando a cada um particularmente.

Quanto ainda à individualização, vale ressaltar a noção de esprit de corps, que, segundo Orlandi ( $2006 \mathrm{a}$, p. 21- 22), se relaciona tanto ao fundamento democrático das sociedades ocidentais quanto ao contrato social. Nas palavras da autora

...o esprit de corps deriva de um sistema de pensamento particular aos processos de socialização. Ele exige não apenas a expressão de um sentimento de pertencimento a uma comunidade, mas ainda a manifestação de um reconhecimento desse pertencimento. Aparece assim como uma forma de solidariedade (GUGLIELMI et alii, 2005). O sentimento de ser Um no todo da sociedade.

O tema da individualização do sujeito na mídia, mais especificamente na publicidade - em nosso caso, a impressa - passa pelo processo de identificações a que são suscetíveis os indivíduos do complexo social. Este fundamenta-se na existência de um laço, um vínculo que une tanto os grupos quanto os indivíduos. Para Orlandi (2006a, p. 23), desse desejo de pertencimento resulta a necessidade do sujeito de, além de fazer parte de uma 
comunidade de fato (família, empresa, nação etc) integrar o que ela denomina comunidades segundas, para as quais se dirige nosso imaginário. Esclarece a autora que

Essas comunidades são grupos em que cada um pode desempenhar seu desejo de reconhecimento como o reconhecimento de seu desejo e de seu ser. As pessoas têm assim a impressão de fazer parte de um grupo, de um corpo compacto que possui a liturgia e seus rituais comoventes em que a morte não entra. O grupo apaga o arbitrário da existência: o grupo encontra seu florescimento no grupo que, acolhendo-o, legitima, por sua vez, sua existência (Enriquez, ibid). E mais do que símbolos comuns é o mesmo tipo de imaginário que solda o grupo.

Acrescenta-se, ainda, que o sentimento de pertencimento alivia o sujeito, mas não o tira da condição de sujeito faltante ou desejante, conforme a teoria lacaniana. Hartmann (2007, p. 174- 175) aponta que o sujeito está ligado à ideologia pelo desejo, e aí, então, reside toda a dificuldade e resistência em se mudar as relações sociais. Trataremos mais detidamente da problematização sonho-desejo-ideologia nas considerações finais do trabalho.

Como nosso material de análise é constituído apenas por propagandas impressas, consideramos importante analisar a relação do sujeito com o simbólico, mais especificamente a relação do sujeito com o texto, com a leitura.

Orlandi (1995, p. 37) argumenta que em nossa sociedade há um excesso de linguagens. Entretanto, as várias linguagens são uma necessidade histórica do homem que, diante de qualquer objeto simbólico, como o texto, é levado a interpretar, a atribuir sentido, a buscar identificações. Pensar sobre um sujeito capaz de fazer interpretações é pensá-lo defronte múltiplas possibilidades de evocar uma memória discursiva, que se constitui de esquecimentos e de silêncios, sendo estes saberes tanto sociais, quanto históricos e ideológicos. Estes saberes encontram-se inscritos na história e, por meio do interdiscurso, produzem efeitos e, consequentemente, instauram sentidos, que são os gestos de interpretação de quem produz e de quem lê o texto. Para Orlandi (1996a, p. 101) 
Quando lemos estamos produzindo sentidos (reproduzindo-os ou transformando-os). Mais do que isso, quando estamos lendo, estamos participando do processo (sócio-histórico) de produção dos sentidos e o fazemos de um lugar social e com uma direção histórica determinada.

Falando da determinação histórica dos processos de significação, Nunes (1998,

p. 25) observa que

todo leitor tem sua história de leitura e, portanto, apresenta uma relação específica com os textos, com a sedimentação dos sentidos, de acordo com as condições de produção da leitura em épocas determinadas. $\mathrm{O}$ sujeito se constitui como leitor dentro de uma memória social de leitura.

Pode-se perceber, então, que em cada época o leitor se relaciona diferentemente com o objeto simbólico, mantendo uma diferente relação com o texto. O leitor da propaganda, conforme o concebemos, é um leitor virtual (ou ideal), já que não temos possibilidade de acesso aos reais leitores da revista. Assim sendo, este leitor-virtual é uma presença necessária no texto propagandístico, uma vez que é para ele que se dirige o anúncio. Nesse contexto, Orlandi (1996a, p. 104) esclarece que "a função enunciativo-discursiva, que é a do leitor, constitui um sujeito afetado pela sua inscrição no social. Quer dizer que o efeitoleitor é determinado historicamente pela relação do sujeito com a ordem social”. Entendendo o leitor como um sujeito afetado pelo social é que podemos pensar na determinação histórica da leitura, conforme esboçamos.

Considerando alguns aspectos da forma histórica do leitor na atualidade, Nunes (1998, p. 39), aponta “um leitor pragmático, que lê 'cada vez mais rapidamente', tem interesses determinados e, consequentemente, um perfil esboçado conforme a posição sócioeconômica [...]”. Certamente pensando neste público que lê tão rapidamente, percebemos que os publicitários trabalham atentamente sobre a materialidade do discurso, elaborando textos com enunciados curtos e impactantes, assim como anúncios repletos de imagens. 


\section{CONSIDERAÇÕES TEÓRICAS E METODOLÓGICAS}

\subsection{Subsídios teóricos}

A análise está fundamentada na perspectiva teórica da $\mathrm{AD}$, para a qual, nas palavras de Orlandi (2001, p.48): “nem a linguagem nem os sentidos nem os sujeitos são transparentes, eles têm sua materialidade e se constituem em processos em que a língua, a história e a ideologia concorrem conjuntamente". Pêcheux (1995) concebe sujeitos e sentidos como históricos e ideológicos, ou seja, é pelo funcionamento da ideologia que se interpela os indivíduos em sujeitos. Para o autor, "só há ideologia pelo sujeito e para sujeitos” (Ibidem., p. 149).

Buscando estabelecer um dispositivo de interpretação, uma escuta discursiva, Orlandi (2001, p. 59) distingue o dispositivo teórico do dispositivo analítico. O primeiro diz respeito à sustentação do método e ao alcance teórico da disciplina, enquanto o segundo, uma construção do analista face ao corpus, individualiza o quadro teórico.

Segundo a AD, a língua é vista como uma sistematicidade, um sistema aberto e sujeito a equívocos ou falhas. Já o discurso, permeado pelas condições de produção, se constitui no tripé formado pela língua, pelos sujeitos e pela ideologia. A AD, como bem define Orlandi (2001, p. 26), “visa à compreensão de como um objeto simbólico produz sentidos, como ele está investido de significância para e por sujeitos”.

Surgida na França na década de 60, a partir dos trabalhos de Michel Pêcheux, a AD é uma disciplina de entremeio, que agrega a lingüística, a psicanálise e o marxismo, mas que tem um desenho disciplinar que lhe é próprio. Neste campo de saber, o social, o histórico e o lingüístico são interrelacionados. A exterioridade não é vista como contexto, como um "estar fora", mas ela é constitutiva do dizer. Falar em exterioridade para a AD é, deste modo, ligar o texto às condições de produção. Estas incluem os sujeitos, a situação, e o interdiscurso 
(memória discursiva). Passemos então a discorrer sobre os conceitos que formam as condições de produção do discurso.

No que tange ao sujeito, para a $\mathrm{AD}$, o que interessa não é o sujeito empírico, mas a posição sujeito discursiva, na qual intervém as formações imaginárias, ou seja, a imagem que o sujeito faz de si, de seu interlocutor e do próprio objeto do discurso. Segundo a autora, "essas posições não são neutras e se carregam de poder que as constitui em suas relações de força" (Orlandi, 2006b, p. 16).

Ainda no que diz respeito ao sujeito, Orlandi trata da forma-sujeito, definida como "a forma de existência histórica de qualquer indivíduo" (Ibid., p. 18). É importante ressaltar que a forma-sujeito é resultante da interpelação ideológica e, portanto, difere em sua constituição histórica. A forma-sujeito atual - o sujeito capitalista - em muito difere da forma-sujeito da Idade Média, por exemplo. Naquela época, a interpelação era basicamente religiosa, e hoje, os processos de interpelação se relacionam com o direito e a identificação, dentre outros fatores.

A situação, em termos discursivos, pode ser pensada em sentido estrito e em sentido lato. Este compreende o contexto social, histórico e ideológico (mais amplo); enquanto aquele tem a ver com as circunstâncias de enunciação, ao contexto imediato. Eles são separados por uma questão didática, porém são indissociáveis, funcionam conjuntamente.

Segundo Orlandi, o interdiscurso é todo o conjunto de coisas já ditas, que preside todo o dizer. Ela o define como "ele é o saber, a memória discursiva" (2006b, p. 18). Em suma, o interdiscurso é responsável pela constituição dos sentidos, uma vez que, para que uma palavra faça sentido é necessário que ela já faça sentido historicamente. Isso nos leva a pensar na ilusão construída pelo sujeito, que pensa ser a fonte de seu dizer. Em outras palavras, o sujeito, pelo efeito de transparência da linguagem, "apaga" dela a sua historicidade e não percebe seu "assujeitamento" pelo interdiscurso. Ele é o horizonte de significações que 
preside todo dizer. Quando enuncia, o sujeito fala de uma região do interdiscurso (GUIMARÃES, 2005).

A AD critica a concepção de linguagem como mero instrumento de comunicação, já que, para esta disciplina, a linguagem serve para comunicar e para não comunicar. Para Pêcheux (1995), o discurso pode ser definido como "efeito de sentidos entre locutores". Tais efeitos se devem às condições de produção, bem como aos sujeitos, sempre atravessados pelo simbólico e afetados por suas memórias discursivas. Então, esta crítica dirige-se ao esquema proposto por Jackobson, no qual um emissor formula uma mensagem pautada num código, e um receptor decodifica esta mensagem, formulando, por seu turno, uma outra, num processo praticamente mecânico. Diz-se "efeito de sentido" porque este não é fixo, nem tem uma referência direta ao mundo ou ao pensamento. Esse efeito seria então produzido nas relações entre os enunciados e entre os sujeitos, dentro das práticas discursivasos discursos.

Em relação à Lingüística, mais especificamente ao Estruturalismo, Pêcheux faz uma leitura de Saussure, e se posiciona favoravelmente ao fato de a língua ser social, mas não a considera como sistema abstrato e homogêneo, mas sim como sistematicidade. Ou seja, trata a língua no mundo, (re)considerando o sujeito que havia sido deixado de lado por Saussure. Pêcheux questiona ainda a Lingüística por negligenciar a historicidade dos sentidos. Em suma, para a Análise de Discurso a linguagem tem uma relação necessária com a exterioridade, o que nos permite trabalhar com as condições de produção do discurso.

Quanto ao Marxismo, mais especificamente ao Materialismo Histórico, ele chega até a AD por uma leitura de Marx realizada por L. Althusser em Ideologia e Aparelhos Ideológicos do Estado (1980). O Materialismo Histórico considera que o homem faz história, mas que ela não lhe é transparente. O que a Análise de Discurso questiona é que a própria história tem o seu real afetado pelo simbólico. Além disso, quando se fala em história na 
Análise de Discurso não se trata de cronologia, já que ela relaciona-se a práticas e não ao tempo em si. Daí, então, falar na historicidade dos sentidos.

No que tange à contribuição da Psicanálise, a Análise de Discurso concorda com o deslocamento da noção de homem para a de sujeito, mas acrescenta aos estudos o conceito de ideologia considerando-a como materialmente relacionada ao inconsciente, sem que este a absorva. Esta disciplina mostra que ideologia e inconsciente se ligam materialmente na língua. Para a AD a ideologia é um mecanismo de produção de evidências, é a ideologia que "faz crer" na transparência dos sujeitos, dos sentidos e da história.

No tocante a relação entre texto e discurso, entende-se o texto como unidade de análise do discurso, sem entretanto consistir no objeto. O texto, pois, evidencia as regularidades do discurso pela referência a uma ou outra formação discursiva, mostrando sua relação com as formações ideológicas. No texto não há somente uma formação discursiva, mas várias, que se organizam em torno de uma formação discursiva dominante. Para Orlandi (2001, p. 15-16)

\begin{abstract}
a Análise de Discurso não trabalha com a língua enquanto um sistema abstrato, mas com a língua no mundo, com maneiras de significar, com homens falando, considerando a produção de sentidos enquanto parte de suas vidas, seja enquanto sujeitos, seja enquanto membros de uma determinada forma de sociedade.
\end{abstract}

Se temos linguagens diferentes, temos, conseqüentemente, diferentes matérias significantes. A AD vê a linguagem em sua complexidade e multiplicidade, analisando, pois, com as diversas materialidades dos discursos, e procurando entender as especificidades e o funcionamento da linguagem. Trabalhando com as diversas formas materiais (textos escritos, orais, imagens, o corpo etc.), esta disciplina concebe todo processo de produção de sentidos com sua materialidade. Orlandi, no mesmo texto, afirma que não há um sentido, mas muitos 
sentidos então, "é na prática material significante que os sentidos se atualizam, ganham corpo, significando particularmente".

Tanto as palavras quanto as imagens, enquanto matérias simbólicas, têm sua materialidade e consistência significativa próprias. Para a AD cores e imagens fazem parte das condições de produção do discurso. Seria um efeito ideológico pensar que todo sistema signos pode ser expresso pela linguagem verbal, embora verbal e não-verbal sejam intercambiáveis, em certas condições. Estabelece-se, nessas circunstâncias, uma paráfrase. (ORLANDI, 1995). Nos textos propagandísticos tomados para nossa análise, entendemos que o verbal e o imagético estão imbricados na materialidade do anúncio. Eles funcionam conjuntamente, podendo haver a retomada de um pelo outro, numa relação de intercambialidade.

\subsection{Dispositivo analítico}

Em Análise de Discurso existe a distinção entre dispositivo teórico e dispositivo analítico de interpretação, tal qual formulado por Orlandi (2001). O dispositivo teórico diz respeito à sustentação do método discursivo, sendo provisório, já que sempre surgem novos conceitos. O dispositivo analítico, por sua vez, muda a cada análise em virtude da natureza do material analisado, da questão posta pelo analista e da finalidade da análise empreendida. Nesta pesquisa, nos propusemos a analisar somente as páginas publicitárias da revista Veja, num certo espaço de tempo, o que constitui um recorte de análise. A finalidade da análise é compreender, no funcionamento discursivo do discurso publicitário, como se dá o processo de individualização do sujeito na contemporaneidade. Como já falamos do dispositivo teórico da interpretação, passaremos a exposição de alguns conceitos primordiais 
para nosso estudo, dado nosso recorte de análise, e sendo estes mobilizados no decorrer de nosso percurso, constituindo, pois, nosso dispositivo analítico.

\subsubsection{Condições de produção}

Este conceito é muito caro à $\mathrm{AD}$ e tem lugar de destaque nesta teoria. Desenvolvido por Pêcheux (1993, p. 78), ele se refere aos fatores extra-lingüísticos que são constitutivos do discurso por explicitarem o funcionamento discursivo. Diz o fundador da AD que

Os fenômenos lingüísticos de dimensão superior à frase podem efetivamente ser concebidos como um funcionamento, mas com a condição de acrescentar imediatamente que este funcionamento não é integralmente lingüístico, no sentido atual desse termo e que não podemos defini-lo senão em referência ao mecanismo de colocação dos protagonistas e do objeto de discurso, mecanismos que chamamos "condições de produção."

Para Orlandi (2001, p. 30), as condições de produção compreendem os sujeitos, a situação de produção do discurso (enunciação e conjuntura sócio-histórica), e também a memória discursiva ou interdiscurso.

As condições de produção se relacionam com as formações sociais e com os lugares ocupados pelos sujeitos nestas formações. Parafraseando Pêcheux, Nunes (2001, p. 12) que

as condições de produção envolvem a relação entre sujeito e história, articulando uma concepção psicanalítica do sujeito aos estudos da ideologia, articulação que não ocorre sem contradições, mas que coloca questões tanto para a linguística como para os estudos da subjetividade.

A relação entre o sujeito e o real não se dá de maneira direta, mas antes, mediada pelas representações imaginárias. É por meio do imaginário que os sujeitos significam o real no discurso, já que o real em sua plenitude é inalcansável. O que há são pontos de contato com o real, sempre mediados pelo imaginário. O discurso da propaganda, 
nesse sentido, como todo discurso, nunca é completo, nem tampouco reflete diretamente a realidade, pois a ele corresponde a uma projeção imaginária do real: de um público leitor, de uma concepção de língua e de sociedade.

Contextualizando o conceito de condições de produção no que diz respeito às propagandas, ressaltamos que tal conceito nos leva a refletir sobre a produção dos textos propagandísticos, no que concerne a posição daquele que a elabora, o publicitário, em determinadas conjunturas sociais e históricas. Nas condições de produção estritas (circunstâncias da enunciação), considerando a posição do publicitário, explicitam-se as imagens do leitor e do próprio anúncio: Quem fala o que? Para quem? Em que situação? De que se fala? Nosso interesse, assim, recai sobre as projeções imaginárias construídas na materialidade do anúncio. Já nas condições de produção amplas, há de se considerar a relação dos textos publicitários analisados com a conjuntura sócio-histórica e ideológica na qual eles se inserem. A revista selecionada também faz parte das condições de produção do discurso (cf. Capítulo 3). Falando das condições de produção no processo criativo do discurso publicitário, Hansen (2009, p. 117) argumenta que

[...] o publicitário, ao produzir o discurso, está marcado por estas determinadas condições de produção. Logo, não são apenas os saberes deslocados do interdiscurso e os recortes de elementos do senso comum as únicas naturezas de exterioridade inscritas no espaço discursivo do processo criativo. As condições de produção se juntam às diferentes naturezas da exterioridade que compõe o processo criativo do discurso publicitário. Por essa razão, o que está sendo formulado no momento da produção do discurso publicitário é formulado em condições dadas, determinado pela relação que estabelece com o exterior.

Nas propagandas que analisamos, as datas de publicação da revista em que os anúncios estão contidos, são consideradas condições de produção do discurso. Percebemos, pois, que as datas festivas (dia dos pais, dia das mães, dia dos namorados etc.) são incorporadas à materialidade do anúncio, sendo o mesmo elaborado de modo a interpelar o leitor a adquirir o produto que estaria relacionado com a data comemorativa. 
Abordamos as condições de produção amplas no primeiro capítulo deste trabalho. As condições de produção estritas serão discutidas mais detalhadamente no terceiro capítulo, ao tratarmos da análise dos textos propagandísticos. Passemos agora a falar das formações discursivas presentes no discurso publicitário.

\subsubsection{Formações discursivas}

O conceito de formação discursiva foi desenvolvido inicialmente por Michel Foucault em Arqueologia do Saber (2000). Para este autor (Ibidem, p. 43), a formação discursiva se define

no caso em que se puder descrever, entre certo número de enunciados, semelhante sistema de dispersão, e no caso em que entre os objetos, os tipos de enunciação, os conceitos, as escolhas temáticas, se puder definir uma regularidade (uma ordem, correlações, posições e funcionamentos, transformações) diremos, pois, por convenção, que se trata de uma formação discursiva.

Para Foucault, como se vê, a formação discursiva é definida em termos da dispersão de textos e das regularidades entre os mesmos. O autor, portanto, não trabalha com o conceito de ideologia, nem com a luta de classes sociais, como o faz Michel Pêcheux. Podemos dizer, assim, que não há continuidade e similaridades conceituais entre esses autores.

Pêcheux, por sua vez, dá novo contorno ao conceito de formação discursiva, a partir de sua posição materialista. Ele desloca este conceito ao relacioná-lo com o lingüístico, ou seja, concebendo a língua como a base material na qual se desenvolvem os processos discursivos. Para o fundador da $\mathrm{AD}$ as formações discursivas representam as formações ideológicas na linguagem. Pêcheux (1995, p. 160-161) explicita que

chamaremos, então, formação discursiva aquilo que, numa formação ideológica dada, isto é, a partir de uma posição dada numa conjuntura dada, determinada pelo estado da luta de classes, determina o que pode e deve ser dito (articulado sob a forma de uma arenga, de um sermão, de um panfleto, de uma exposição, de um programa, etc.). 
O ponto nodal deste embricamento entre formações discursivas e formações ideológicas seria a interpelação. Desta maneira, os indivíduos são interpelados em sujeitos pelas formações discursivas, representantes das formações ideológicas na linguagem. Lembramos ainda que as formações discursivas podem funcionar como memória para os sujeitos que com ela se identificam.

Segundo Orlandi (2001, p. 44), a análise das formações discursivas permite ao analista de discurso estabelecer regularidades no funcionamento discursivo. A autora conclui observando que as formações discursivas não devem ser pensadas como "blocos homogêneos", posto que elas são constituídas pela contradição, são "heterogêneas nelas mesmas e suas fronteiras são fluidas, configurando-se e reconfigurando-se continuamente em suas relações".

Para a AD, o sentido só é possível porque o sujeito se insere em uma formação discursiva, e esta, por sua vez, está inserida num âmbito mais complexo, dentro de territórios sócio-históricos que são as formações ideológicas. Como a formação discursiva é heterogênea, assim também o é a forma-sujeito, cabendo a esta a tomada de posições, em consonância com a posição de sujeito que assume, sendo, ainda, interpelado pela ideologia. Para Althusser (1980), em Ideologia e Aparelhos Ideológicos do Estado, “a ideologia é uma ‘representação' da relação imaginária dos indivíduos com suas condições reais de existência”.

Relacionando o conceito de formações discursivas ao discurso publicitário, afirmamos que o estudo das formações discursivas permite identificar diferenças significativas entre discursos presentes em uma conjuntura, bem como explicar algumas transformações na passagem de um a outro estado de um processo discursivo, sempre remetendo-as a formações ideológicas. Nesse sentido, percebemos a formação discursiva capitalista como dominante no discurso publicitário, bem como a identificação do sujeito 
contemporâneo com a mesma. Daí resulta o propalado consumismo que caracteriza nossos dias.

Deste modo, com a articulação do estudo das condições de produção, das formações discursivas e do interdiscurso como pressuposto teórico-discursivo tem-se o procedimento a ser seguido pelo analista de discurso em busca dos sentidos do processo discursivo. Partindo desse pressuposto é que analisamos os textos publicitários, tomados como objeto discursivo.

\subsubsection{Formações imaginárias}

No discurso, o que funcionam são imagens que resultam de projeções e não os sujeitos empiricamente inscritos na sociedade. Tais projeções permitem a passagem das situações empíricas - os lugares dos sujeitos - às posições dos sujeitos no discurso. As posições, por sua vez, "significam em relação ao contexto sócio-histórico e à memória, isto é, o saber discursivo, o já-dito”. (Orlandi, 2001, p. 40).

Há, nos discursos, relações de sentido que possibilitam fazer antecipações do que seu interlocutor vai pensar, o modo que ele interpretará aquilo que foi dito. Segundo Orlandi (Ibidem, p. 39), esse mecanismo de antecipação "regula a argumentação, de tal modo que o sujeito dirá de um modo, ou de outro, segundo o efeito que pensa produzir em seu ouvinte”. Ressaltamos ainda que esta antecipação imaginária construída pelo locutor de seu interlocutor está calcada no já- dito, isto é, na memória discursiva. Para Pêcheux (1993, p. 85), as formações imaginárias "resultam, elas mesmas, de processos discursivos anteriores (provenientes de outras condições de produção) que deixaram de funcionar, mas que deram nascimento a 'tomadas de posição' implícitas que asseguram a possibilidade do processo discursivo em foco". 
Tratando do ponto de vista do sujeito como um "objeto imaginário", Pêcheux (Ibidem, p. 83) fala de um jogo de imagens no discurso, no qual emergem questões como “Quem sou eu para lhe falar assim?”, “Quem é ele para que eu lhe fale assim?”, “Quem sou eu para que ele me fale assim?”, “Quem é ele para que me fale assim?”. Conforme as condições de produção do discurso, uma dessas questões pode tornar-se dominante. No discurso estudado, acreditamos que seja “Quem é ele para que eu lhe fale assim?”, já que o texto da propaganda é elaborado com base na antecipação de quem seja o interlocutor, buscando interpelá-lo, agradá-lo.

Visando, pois, produzir determinados efeitos sobre o leitor - um possível consumidor - o publicitário elabora o anúncio tendo em mente o público que deseja atingir, como, por exemplo, as mulheres (anúncios da SulAmérica e da Lojas Renner), os executivos (série Tecnologia), os universitários, os que têm maior poder aquisitivo (propagandas de carros luxuosos; anúncio do Itaú Personnalité), etc.

De acordo com Orlandi (2001), as condições de produção envolvem o mecanismo imaginário, ou seja, o mecanismo de produção de imagens do sujeito, do objeto do discurso em uma conjuntura sócio-histórica. Neste contexto, nos interessam a imagem do leitor dos anúncios construída pelo discurso da propaganda. É a essa imagem, essa projeção imaginária a que chamamos leitor-virtual. Entretanto leitor real e leitor virtual estão num espaço tenso, pois não são categorias estanques: o leitor que efetivamente lê a propaganda é, ao mesmo tempo, um leitor real e virtual.

Colocando o leitor como consumidor da publicidade, Hansen (2009, p. 180) distingue o leitor real do leitor virtual. Para ele, “o leitor virtual é aquele para quem um autor escreve e a quem atribui certos conhecimentos, opiniões, preferências, experiências. Já os leitores reais são aqueles que efetivamente lêem o texto". 
Falando sobre a relação entre quem elabora o anúncio (o publicitário) e o leitor, relação esta baseada no jogo do imaginário, Hansen (Ibidem, p. 181) aponta que

$\mathrm{Na}$ ânsia de evitar a imposição para conquistar a cumplicidade do leitor, o publicitário, ao projetar tal imagem e construir um leitor virtual, cria um efeito de abertura em seu discurso, convocando o leitor a atribuir sentido, dando um efeito de coletividade, muitas vezes manifesto pela dominância da função apelativa que instaura uma pretensa proximidade com o leitor. Por intermédio da ilusão da qual ele mesmo é marcado, o seu discurso é personalizado, dirigido, especialmente elaborado para quem lê, produzindo o efeito de individualizar o leitor, evitando massificá-lo, tornando-o, ilusoriamente, único, exclusivo, a fim de estreitar a relação, de criar intimidade.

É justamente este "estreitar a relação", este "criar intimidade" que nos interessa nesta pesquisa. Em outras palavras, esta relação de intimidade entre o texto propagandístico e o leitor se constrói no processo de individualização do sujeito que se dá no interior do discurso publicitário.

\subsection{O corpus e os procedimentos analíticos}

Para a $\mathrm{AD}$, a unidade empírica de análise é o texto, pois é ele que remete o analista às sistematicidades e às condições de produção do discurso. Esta disciplina concebe a língua como uma relação entre estrutura e acontecimento, criticando o que Orlandi chama de conteudismo. Em outras palavras, o analista não busca um sentido "oculto" no texto; ele busca sua discursividade, o modo como, em seu funcionamento, o texto produz sentidos. Pensar o funcionamento do texto é ligá-lo à sua exterioridade, às suas condições de produção. Em nossa pesquisa, partindo do texto enquanto fato discursivo, buscamos explicitar as regularidades do discurso publicitário - mais especificamente do processo de individualização do sujeito - fazendo referência às formações discursivas ali presentes e mostrando como elas se relacionam com as formações ideológicas. Segundo Orlandi (2001, p.62), "a delimitação do corpus não segue critérios empíricos (positivistas) mas teóricos”. Não se busca em Análise 
de Discurso a exaustividade horizontal do corpus, mas sim a exaustividade vertical que nos leva a tratar o material de análise "com sua memória, sua espessura semântica, sua materialidade lingüístico-discursiva."

O método empregado é o lingüístico-histórico, o qual descreve as sistematicidades lingüísticas e evidencia a relação entre sujeito, língua e história, procurando mostrar a historicidade dos sentidos, e relacionando o discurso aos aspectos históricos e ideológicos de sua constituição. O que se propõe, pois, é um batimento entre a descrição das marcas lingüísticas e a sua interpretação, relacionando as marcas lingüísticas às condições de produção “Então, para a análise de discurso, o que interessa não é a organização linguiística do texto, mas como o texto organiza a relação da língua com a história no trabalho significante do sujeito em sua relação com o mundo. É dessa natureza sua unidade: lingüístico-histórica" (Orlandi, 2001, p. 69).

Para a $\mathrm{AD}$, a análise do corpus deve alternar descrição e interpretação. A interpretação não implica uma análise subjetiva do analista, ao contrário, ela deve ser o menos subjetiva possível "explicitando o modo de produção de sentidos do objeto em observação" (Orlandi, 2001, p.64). Daí a importância do dispositivo teórico, para orientar o trabalho do analista com o corpus, com os sentidos e com a interpretação. Vale lembrar que o objetivo do analista é compreender os sentidos, as interpretações, e não dizer qual é o sentido verdadeiro ou certo de um texto. Ele trabalha com o funcionamento da linguagem, do discurso, e não com conteúdos.

O procedimento de análise consiste de duas etapas. Na primeira, passa-se da superfície lingüística (o material bruto coletado) para o objeto discursivo. Na segunda, há uma passagem do objeto discursivo (corpus de-superficializado) para o processo discursivo. Alcançado o processo discursivo, o analista não precisa mais dos textos, uma vez que estará de posse do funcionamento discursivo, que se estende a outros textos. Pêcheux (1995, p. 161) 
define processo discursivo como "o sistema de relações de substituição, paráfrases, sinonímias, etc., que funcionam entre elementos lingüísticos - 'significantes' - em uma formação discursiva dada".

É no terreno da polissemia que se faz produtiva uma análise discursiva, pois não lidamos com a estabilização, ao contrário, contamos com a desestabilização dos sentidos, a multiplicidade deles e seus deslocamentos. Na polissemia, portanto na efervescência dos processos de significação, é que se ancora o discurso publicitário. A AD, assim, procura compreender o movimento dos sentidos e não os sentidos prontos, numa ilusão de estabilidade. Orlandi (2001, p. 37) argumenta que "a criatividade implica na ruptura do processo de produção da linguagem, pelo deslocamento das regras, fazendo intervir o diferente, produzindo movimentos que afetam os sujeitos e os sentidos na sua relação com a história e com a língua. Irrompem, assim, sentidos diferentes”.

Se focalizarmos o mesmo e o diferente, perceberemos dois processos discursivos: a paráfrase e a polissemia, ambos utilizados pela publicidade. A polissemia cria novos sentidos, jogando sempre com o equívoco, enquanto a paráfrase apóia-se num sentido anterior, retornando aos mesmos espaços do dizer, como se vê, por exemplo, nos estereótipos.

Pelo processo de de-superficialização do texto (Orlandi, 2001, p. 65), ou seja, partindo da superfície textual para o objeto discursivo, buscarmos compreender a maneira como o discurso publicitário se textualiza, dando relevo ao processo de individualização do sujeito neste discurso.

Considerando que "não há discurso fechado em si mesmo, mas um processo discursivo" (Idem., Ibidem, p. 62), fizemos um recorte do corpus não visando a exaustividade, pois para a $\mathrm{AD}$ ele consiste em um fragmento de linguagem que se associa às suas condições de produção. Feito o recorte, cada propaganda é um texto, um fato discursivo a ser analisado, considerando as marcas lingüísticas e não-lingüísticas do processo de individualização ali 
presentes. Conforme exposto por Pêcheux, a $\mathrm{AD}$ não se constitui em um dispositivo de análise que dá conta de todas as nuances de sentido, nem sendo este intento possível. O que aqui procuramos é identificar, descrever e analisar os processos de produção de sentidos em um corpus específico, as propagandas impressas, que, por seu turno, foi recortado pela formulação da análise. Analisamos, pois, a relação entre o verbal e o não-verbal dos anúncios, as marcas lingüísticas e não-linguísticas da individualização, as condições de produção do discurso publicitário, o jogo de imagens. Depois de realizada a de-superficialização, percebemos as regularidades e as formações discursivas do texto, que, por sua vez, nos levaram ao objeto discursivo. Esclarece Orlandi (2001, p. 66) que

o objeto discursivo não é dado, ele supõe um trabalho do analista e para se chegar a ele é preciso, numa primeira etapa de análise, converter a superfície lingüística (o corpus bruto), o dado empírico, de um discurso concreto, em um objeto teórico, isto é, um objeto lingüisticamente de-superficializado, produzido por uma primeira abordagem analítica que trata criticamente a impressão de 'realidade' do pensamento, ilusão que sobrepõe palavras, idéias e coisas.

Orlandi (1996b) aborda o texto como uma unidade complexa, no sentido de que é composta pela que ela denomina de individualizações. Em outras palavras, o texto consiste num conjunto de unidades individuais que, somadas, caracterizam a unidade discursiva. Tais unidades individuais são a representação textual das formações discursivas, que, devido à sua multiplicidade (há uma formação discursiva dominante em torno da qual se organizam outras secundárias) dão o caráter de heterogeneidade ao texto. Pelo que foi exposto, depreendemos que o texto é heterogêneo quanto:

- À natureza das linguagens: escrita e oral.

- À natureza dos materiais simbólicos, que podem ser imagens, letras, sons etc. 
- Às posições do sujeito e às formações discursivas.

Devido à heterogeneidade do texto, e, portanto, às suas múltiplas possibilidades de leituras, ele não se esgota em uma única descrição, podendo ser novamente analisado de outro modo. Feitos outros recortes, há, consequentemente, outras interpretações possíveis.

A escolha do corpus em Análise do Discurso, portanto, não está totalmente dissociada de uma primeira interpretação do corpus, pois é apenas com base nos objetivos de análise que se torna plausível a delimitação do material de análise. Quando me propus a analisar o processo de individualização no discurso da propaganda optei por selecionar somente as propagandas individualizantes. Dado meu recorte no critério de seleção do corpus, posso tecer considerações sobre como funciona o processo, mas, por outro lado, meu recorte não me permite falar sobre todas as propagandas da Veja no período que selecionei. Não posso afirmar, por exemplo, que todas as propagandas da revista são individualizantes.

O corpus foi retirado de 12 exemplares da revista Veja do ano de 2008, no período de Maio a Julho, mas não analisei todas as propagandas contidas nas revistas nestes meses, conforme já mencionei. Esta revista semanal de atualidades traz uma gama diversificada de temas e grande número de anúncios, e se destina ao público jovem-adulto, com médio poder aquisitivo e médio nível de escolaridade.

Delimitado o corpus, efetuamos os recortes, de acordo com os objetivos de análise. Feito o recorte, cada propaganda é um texto, um fato discursivo a ser analisado, considerando as marcas lingüísticas e não-lingüísticas do processo de individualização ali presentes. Analisaremos, pois, a relação entre o verbal e o não-verbal das séries de anúncios. Depois de realizada a de-superficialização, percebemos as regularidades e as formações 
discursivas do texto, que, por sua vez, nos levaram ao objeto discursivo. Segmentamos o corpus em séries temáticas, as quais estão distribuídas da seguinte forma:

\author{
Série "Bancos" (Propagandas 21 a 25) \\ Série "Serviços" (Propagandas 09 a 12) \\ Série "Automóveis e motocicletas" (Propagandas 04 a 08) \\ Série "Tecnologia" (Propagandas 17 a 20) \\ Série "Turismo" (Propagandas 01 a 03) \\ Série "Cuidados pessoais" (Propagandas 13 a 16)
}

Segundo Nunes (1994, p. 115), “ao falarmos em tema, não pressupomos que haja um referencial fixo (seja discursivo ou real) sobre o qual o discurso se detém. É preciso levar em conta as condições de produção em que ele se insere". Quanto ao material de análise, acrescenta o autor que deve ser "considerado em vista das séries discursivas que se apresentam nos textos, construindo espaços de identificação, transformação, contradição etc".

\title{
2.4 Enunciação: o locutor e o enunciador em foco
}

Tratamos anteriormente de conceitos cruciais para nossa pesquisa, que constituem nosso dispositivo analítico de interpretação. Além deles, é mister abordarmos a questão da enunciação para melhor entendermos o processo de individualização do sujeito no discurso publicitário, já que trabalharemos também com as marcas lingüísticas da enunciação.

No capítulo 3, no qual afunilaremos ainda mais nossas análises, mobilizaremos os conceitos de enunciação, locutor e enunciador, que passaremos agora a explicar. 
Trabalhamos com os conceitos de locutor e de enunciador como os formula Guimarães, em Semântica do Acontecimento (2005). Nesta obra, o semanticista se posiciona numa linha de filiações teóricas próxima aos estudos de Ducrot e de Benveniste. Contudo, Guimarães faz deslocamentos importantes às formulações daqueles, e dá a seus estudos contornos teóricos e metodológicos que lhes são muito próprios.

Quanto à definição de enunciação, Benveniste (em “Aparelho Formal da Enunciação") postula que o sujeito apropria-se da língua para enunciar. Para ele, "a enunciação é a língua posta em funcionamento pelo locutor" (BENVENISTE apud GUIMARÃES, 2005, p. 11).

Ducrot (apud GUIMARÃES, 2005, p. 11), por sua vez, apresenta a enunciação como um "evento do aparecimento de um enunciado". Para esse autor, o enunciado é um segmento do discurso, sendo ainda um fenômeno empírico que dependeria de um tempo, um lugar, um produtor, e um ou mais ouvintes. Para Ducrot, ainda, o enunciado não se repete, pois a cada nova enunciação, mesmo que da mesma sequência discursiva, se produz um novo enunciado. Em suma, para ele, o valor semântico do enunciado é o sentido, consistindo este, pois, em sua especificidade semântica.

Guimarães (Ibid.), por seu turno, analisa a enunciação considerando o histórico, o político e o simbólico. Seus estudos semânticos, assim, mantêm um constante e fecundo diálogo com a Análise de Discurso, nossa perspectiva teórica. Para o autor, os estudos enunciativos trazem à baila a questão do sujeito (que enuncia) e da língua. Em síntese, Guimarães toma a enunciação como uma prática política, que põe a língua em funcionamento por um sujeito. Para ele, ainda, são quatro os elementos fundamentais para se conceituar a enunciação: a língua, o sujeito, a temporalidade e o real. Falando da enunciação como acontecimento, o semanticista explica que 
Dois elementos são decisivos para a conceituação deste acontecimento de linguagem: a língua e o sujeito que se constitui pelo funcionamento da língua na qual enuncia-se algo. Por outro lado, um terceiro elemento decisivo, de meu ponto de vista, na constituição do acontecimento, é sua temporalidade. Um quarto elemento ainda é o real a que o dizer se expõe ao falar dele. Não se trata aqui do contexto, da situação, tal como pensada na pragmática, por exemplo. Trata-se de uma materialidade histórica do real. Ou seja, não se enuncia enquanto ser físico, nem meramente no mundo físico. Enuncia-se enquanto ser afetado pelo simbólico e num mundo vivido através do simbólico. (GUIMARÃES, 2005, p. 11).

Outro importante deslocamento teórico feito por Guimarães ao longo de sua obra, foi tratar da enunciação sem remetê-la a uma centralidade do sujeito, como o fazem Ducrot ou Benveniste. Para ele, portanto, não é o sujeito, o locutor que temporaliza, mas sim a própria enunciação enquanto acontecimento de linguagem.

Definido o que entendemos por enunciação, nos deteremos a seguir a discorrer sobre o locutor e o enunciador.

Para Benveniste, como já mencionamos, o locutor define-se como aquele que diz "eu" no discurso, apresentando-se como fonte do dizer e, como tal, temporalizando o acontecimento da enunciação. Este "eu" só existe em relação a um "tu” a quem se dirige numa relação de reciprocidade.

Ducrot afirma que o locutor é aquele a quem se atribui a responsabilidade pelo enunciado. O enunciador seria o ponto de vista a partir do qual se fala, uma projeção do locutor. Pode haver, então, mais de um enunciador num mesmo enunciado. Para Ducrot, o autor efetivo do enunciado é denominado sujeito empírico. Fazendo uma analogia com os textos literários, Ducrot aproxima o locutor ao narrador da história, o enunciador às personagens, e o sujeito empírico ao autor do texto.

Em formulação mais recente e elaborada, Guimarães define o que entende por locutor e enunciador. Ambos, para ele, são figuras da enunciação, que, por seu turno, ocupam lugares enunciativos dentro de cenas enunciativas. Estas, "são especificações locais nos 
espaços de enunciação" (GUIMARÃES, 2005, p. 23). Mais adiante, no mesmo texto, o autor afirma que

\begin{abstract}
A cena enunciativa é assim um espaço particularizado por uma deontologia específica de distribuição dos lugares de enunciação no acontecimento. Os lugares enunciativos são configurações específicas do agenciamento enunciativo para 'aquele que fala' e 'aquele para quem se fala'. Na cena enunciativa 'aquele que fala' ou 'aquele para quem se fala' não são pessoas mas uma configuração do agenciamento enunciativo. São lugares constituídos pelos dizeres e não pessoas donas de seu dizer. (Idem.; Ibidem, p. 23)
\end{abstract}

Retomando Ducrot, Guimarães postula que ao locutor corresponde o lugar do qual se enuncia, assumindo a palavra. Sintetizando, ele esclarece que

Assumir a palavra é por-se no lugar que enuncia, o lugar do Locutor, que vou chamar de Locutor (com maiúscula), ou simplesmente L. L é então o lugar que se representa no próprio dizer como fonte deste dizer. E desta maneira representa o tempo do dizer como contemporâneo deste mesmo L, e assim representa o dizer como o que está no presente constituído por este L. (Id.; Ibid, p. 23-24)

Para finalizar, falemos da figura da enunciação que nos é mais cara nesta pesquisa: a do enunciador.

O enunciador consiste na representação do lugar social de dizer do locutor, apagando-se, na enunciação, tanto seu cunho social quanto histórico, embora, vale lembrar, sempre se enuncia em dada conjuntura sócio-histórica.

A figura do enunciador, enquanto um lugar constituído por seu dizer, caracteriza-se por uma maneira peculiar de pôr as palavras em funcionamento. Deste modo, Guimarães distingue três enunciadores, e assim sucintamente os caracteriza:

[...] a cena enunciativa coloca em jogo, também, lugares de dizer que estamos aqui chamando de enunciadores. E estes se apresentam sempre como a representação da inexistência dos lugares sociais de locutor. E 
embora sempre se apresentem como independentes da história ou fora da história, são lugares próprios de uma história. Temos então enunciadores como: enunciador-individual, quando a enunciação representa o Locutor como independente da história, enunciador-genérico, quando a enunciação representa o Locutor como difuso num todos em que o indivíduo fala como e com outros indivíduos; enunciador-universal, quando a enunciação representa o locutor com fora da história e submetido ao regime do verdadeiro e do falso. (Id.; Ibid, p. 23-26)

Como já dito anteriormente, retomaremos em detalhes o que foi exposto nesta seção do texto no capítulo de análise do trabalho, no qual nos deteremos nas marcas lingüísticas e não-lingüísticas do processo de individualização do sujeito no discurso da propaganda. 


\section{ANÁLISE DAS SÉRIES}

No capítulo precedente, apresentamos a perspectiva teórica e a metodologia que embasam nossa pesquisa. Prosseguiremos com a análise do corpus, que, como já dissemos, foi segmentado em séries temáticas.

Consideramos a Veja como parte das condições de produção. Por isso, fomos ao site da revista ${ }^{3}$ para percebermos o lugar e a importância das propagandas na publicação do grupo Abril. Na internet, encontramos que a "distribuição da revista atinge mais de 30 mil pontos de venda no Brasil e garante aos anunciantes uma grande projeção em todo país”, o que nos indica que os interlocutores das propagandas que analisamos não são somente moradores de regiões metropolitanas, como se poderia pensar, mas a maior parte da população brasileira. A abrangência de Veja faz suas propagandas circularem em várias regiões, e possibilita aos anunciantes maior visibilidade em nível nacional. Talvez por esse motivo, a própria revista enfatize que "tem grande faturamento publicitário", o que nos leva a pensar sobre o que dissemos na introdução sobre o número cada vez maior de propagandas na revista. Além da imagem de um leitor consumista, a Veja vem procurando aumentar seus dividendos.

Quanto ao relacionamento da Veja com seu leitor, o site aponta (baseando-se em pesquisas) que a maioria dos leitores diz ler as propagandas da revista, principalmente se estas forem "inovadoras e diferentes". Relacionando o que foi supostamente dito pelos leitores com nosso corpus, atentamos para o fato de os publicitários buscarem a diferenciação na materialidade, bem como do próprio produto ou serviço anunciado.

\footnotetext{
${ }^{3}$ http://veja.abril.com.br/idade/publiabril/midiakit/index.shtml. Acesso em 15 de junho de 2010 .
} 


\subsection{Série Turismo}

Esta série é composta por três anúncios (propagandas 1 a 3), todos eles da operadora de turismo CVC. Nas revistas selecionadas só encontramos propagandas desta operadora, que atua em todo Brasil e oferece viagens terrestres, marítimas e aéreas. No site da Veja, localizamos que esta oferece "Projetos Publicitários Fechados, desenvolvidos de acordo com a necessidade de um único anunciante". Acreditamos ser este o caso da CVC, num movimento de exclusividade por parte da revista.

O primeiro anúncio está presente na edição da Veja de 23/07/08, o segundo na de 11/06/08 e o terceiro na de 18/06. Considero importante colocar as datas para que depois tratemos das condições de produção dos textos.

Os três textos propagandísticos apresentam pacotes de viagem internacional, interpelando o sujeito-leitor, e trabalhando com o imaginário dos estereótipos do turismo. Neste contexto, podemos depreender o funcionamento discursivo, explicitando as regularidades lingüísticas e as marcas verbais e não-verbais do processo de individualização do sujeito. Destacamos ainda, nesta série, um “jogo" constante entre o coletivo e o individual.

Com efeito, nesta série - e nas demais - as imagens, com sua consistência significativa própria, têm um papel importante na produção de sentidos, e no modo de interpelação ideológica dos sujeitos-leitores. Payer (2005, p. 16) salienta o papel das imagens para a $\mathrm{AD}$ e afirma que

Nesta perspectiva, é de se observar também como o Texto da Mídia, em suas novas formas proporcionadas pelo desenvolvimento da tecnologia, e sobretudo da imagem, opera efeitos com especial força pragmática sobre os indivíduos. A introdução da imagem em larga escala tem assim estatuto semelhante ao da introdução da imprensa na difusão do livro. São específicas as formas de interpelação da imagem na produção de sentidos. Estamos dizendo que se todo discurso tem a propriedade de produzir evidências do real, esta capacidade é diversamente potencializada no discurso produzido na base da imagem. 
O slogan da empresa "Sonhe com o mundo. A gente leva você" evidencia o discurso da mundialização ou globalização, marcando a heterogeneidade discursiva, ou seja, os discursos são sempre atravessados por outros discursos, que os constituem. Nesta série, este discurso se apresenta tanto no verbal (“Sonhe com o mundo”) quanto no não-verbal, com as fotos ilustrativas de outros países, como os Estados Unidos, o Chile e a Argentina.

Em "A gente leva você" temos um enunciador coletivo "a gente" que fala do lugar social da empresa CVC, e que se dirige a um interlocutor individualizado "você", o sujeito-leitor. Ambos são projeções imaginárias do real, que exprimem a posição social tanto de um quanto do outro. O coletivo "a gente" funciona como um pronome pessoal de primeira pessoa do plural (nós), e, juntamente com o pronome de tratamento "você" fazem parte do discurso cotidiano, bem como produzem uma pretensa proximidade entre o grupo, a empresa (“a gente") e o leitor ("você").

Vale ressaltar ainda a teorização do sonho ("Sonhe com o mundo"; "36 anos realizando sonhos"), noção cara à Psicanálise e fundamental para compreendermos o processo de constituição do sujeito. Para Birman (2005, p. 05)

Com efeito, com a tese fundamental de que o sonho é uma realização de desejo, Freud nos disse não apenas que o desejo estava no cerne do sujeito, mas também que era aquele que nos movia e nos dava alento para existir, nos impelindo decididamente para a transformação do mundo e para a criação de novas linguagens.

Nas propagandas do corpus, o sonho fica a cargo do interlocutor identificado por "você", enquanto que à empresa cabe a concretização do sonho enquanto manifestação do desejo. A empresa (“a gente” ou “nós”) é a responsável pela realização do sonho.

As formas imagéticas - nesta série temos apenas fotos e textos - também individualizam o leitor (tanto casais quanto o sujeito individualmente, a mulher), e podem 
funcionar como evocadores da memória, ou mesmo nos remeter à exterioridade, às condições de produção do discurso. Para nós, portanto, as imagens são operadores de memória e de simbolização (Davallon, 2007), dando margem a diferentes interpretações, e gerando identificação entre a propaganda e o leitor. Para a $\mathrm{AD}$, ainda, a memória não tem caráter cognitivo ou psicologizante, mas, antes, tem um cunho social e discursivo.

No anúncio de 23/07, temos a foto de um jovem casal, defronte a Estátua da Liberdade. Percebemos que a foto foi tirada de longe, e no mesmo plano dos fotografados, sendo que o ângulo escolhido privilegia o casal. A técnica ainda evidencia a grandeza de proporções do monumento americano. O casal, sorridente e individualizado, fotografa a si próprio, estando fora do ambiente urbano, que aparece, vagamente, ao fundo. O imaginário contemporâneo contempla o urbano, a cidade como algo que remete ao trabalho, ao cotidiano, ao estresse, contexto nada propício para o sujeito "passar férias". É possível dizer, então, que a foto tanto individualiza quanto mostra muito bem a forma-sujeito atual: o sujeito de direito, dono e responsável de sua vontade e com livre circulação social. De um lado temos o sujeito urbano, conflituoso, estressado, trabalhador, e do outro, vemos o sujeito que escaparia à determinação histórica, buscando um lugar "de descanso". Todavia, como o sujeito é produzido pela determinação histórica ele não pode escapar dela, sendo isso um efeito do imaginário. A individualização do sujeito se dá, então, pela identificação com o texto e com a imagem.

Esta propaganda trabalha ainda com a questão do pré-construído em "Porque você não trabalha 8 horas por dia para passar férias num lugar qualquer". Entendemos o préconstruído como a relação do que veio de outro lugar com o que foi formulado no discurso do sujeito. O pré-construído é a memória da posição discursiva do sujeito da enunciação, dentro de uma formação discursiva. Para Pêcheux (1995, p. 164) “o pré-construído corresponde ao ‘sempre-já-aí' da interpelação ideológica que fornece-impõe a 'realidade' e seu 'sentido' sob 
a forma da universalidade (o 'mundo das coisas')". Aqui, tem-se a representação de um sujeito que trabalha (o que restringe o grupo dos interlocutores), e que trabalha 8 horas diárias. Como "recompensa" de seu trabalho, esse sujeito não mereceria "passar férias num lugar qualquer". Questionamos: que lugar seria esse? Parece-nos, pelas propagandas, que "lugar qualquer" se refere a qualquer lugar que não seja um destino internacional, visto que as fotos retratam os Estados Unidos, o Chile e a Argentina.

Como este anúncio foi publicado no mês de julho, no Brasil um mês de férias escolares, e, assim sendo, com mais opções de vôos internacionais de turismo, remetemos tal fato às condições de produção do discurso. Falando ainda das condições de produção amplas, destacamos que a denominada "classe c", tida como uma classe média com maior poder de consumo, tem viajado cada vez mais. Isso se deve ao barateamento das viagens tanto nacionais quanto internacionais, à facilidade de pagamento e à qualidade dos serviços prestados. Esse novo tipo de viajante dá nova feição ao setor de turismo, e isso pode ser também percebido no funcionamento do discurso publicitário, no modo de interpelação dos sujeitos, buscando sempre a identificação do leitor (possível cliente) com o anúncio.

Diferentemente dos anúncios anteriores, que mostram casais, a propaganda de 18/06 traz a foto de uma jovem mulher fotografando a um monumento na Ilha de Páscoa, Chile. Certamente, tal escolha não é gratuita, e individualiza o sujeito-leitor, a mulher, pela identificação. Se pensarmos nas condições de produção do discurso em sentido amplo, isto é, na conjuntura sócio-histórica em que vivemos, fica aí construída a imagem de mulher independente, que viaja por conta própria.

Os enunciados "Coloque na tela do seu computador uma foto que você mesmo tirou"; e "Não espere que te contem, VIVA VOCÊ MESMO”, individualizam o sujeito leitor. Em "você mesmo" temos a co-referência, isto é, uma referência ao próprio pronome você. O pronome pessoal "você" indica o interlocutor, produzindo o sujeito em sua individualidade. Já 
o pronome "mesmo", retoma "você" por co-referência, reafirnando, então, a própria individualidade do sujeito.

O enunciado "Para todo mundo existe uma CVC" tem um enunciador universal ("todo mundo"), e produz efeitos de evidência do real, já que, como se sabe, com tamanha desigualdade social, são poucas as pessoas que têm condições financeiras de viajar para outro país. Entretanto, “todo mundo" traz esse efeito de evidência, isto é, a propaganda se dirige aos poucos que ganham muito, mas se apresenta como se todos os indivíduos tivessem poder aquisitivo suficiente para comprar o que está sendo oferecido no anúncio.

Com efeito, o discurso publicitário, trabalhando atentamente com o imaginário, ajuda a segmentar a sociedade em "faixas econômicas", já que estamos longe de uma sociedade equânime, nos mais diferentes aspectos.

Nas propagandas de turismo percebemos uma imagem parcial e construída da sociedade contemporânea, na qual são silenciados os problemas e as desigualdades sociais em que vivemos. As propagandas apresentam ao leitor uma sociedade idílica, que, na realidade se opõe à sociedade de contradições em que estamos inseridos. Há, pois, identificações e silenciamentos.

\subsection{Série Automóveis e Motocicletas}

Para esta série (propagandas 04 a 08), selecionamos quatro anúncios de carros e um de motocicleta. Os carros são das marcas Peugeot, Toyota, Mitsubishi e Kia, e a moto é da marca Honda. As motos dessa marca são bastante populares no Brasil, apresentando preços acessíveis. Os carros anunciados, por sua vez, não têm preços populares (dois carros acima de cem mil reais, um acima de cinqüenta mil, e o outro não apresenta preço),o que nos leva a pensar a imagem de leitor e de consumidor que a empresa - e o publicitário - buscavam 
atingir quando da elaboração do anúncio. É este leitor-virtual que a propaganda visa interpelar. Podemos afirmar, em virtude do exposto, que esse leitor-virtual corresponderia à classe média-alta da sociedade brasileira. Em nossos dias, nunca se comprou tantos carros e motos. Isso se deve ao crescente poder de consumo a que chegou a classe média brasileira, bem como à maior facilidade de pagamento, além de incentivos do governo federal, como redução do imposto denominado IPI.

Nesta série temática, algumas características do funcionamento discursivo publicitário são mais ressaltadas. Vejamos.

Primeiramente, destaco a descrição das características dos produtos, que evidenciam sucessivamente a potência, a tecnologia e a sofisticação presente nos veículos. Todos os grifos são meus. Quanto à potência, nesta série, temos:

"Kia Sorento com novo motor diesel VGT 170 cavalos, ainda mais potente". (propaganda 05)

"Novo motor 2.0 L 16v Flex de até 151cv". (propaganda 04)

"Motor turbo diesel intercooler 163cv". (propaganda 07)

Ressaltando a tecnologia presente nos veículos e na motocicleta, os anúncios apresentam:

“Câmbio automático seqüencial Tiptronic System Porsche”. (propaganda 04)

"Painel com tecnologia Optitron". (propaganda 07)

“Computador de bordo, rádio com CD changer para 6 discos com MP3 e arcondicionado automático, digital”. (propaganda 07)

"A Shadow 2009 conta agora com injeção eletrônica [...]" (propaganda 08)

Destacando os aspectos da diferenciação dos produtos e da sofisticação dos mesmos, selecionamos:

"Experimente a combinação perfeita de sofisticação e elegância..." (propaganda 07)

“Bancos de couro". (propaganda 05)

“[...]novas cores e grafismos exclusivos para você”. (propaganda 08) 
Vemos, pelas sequencias discursivas acima, que os anúncios de automóveis têm seu funcionamento baseado no tripé potência, tecnologia e sofisticação, numa síntese da urbanidade, já que se está falando com o sujeito urbano.

Dando prosseguimento em nossa análise, notamos que as propagandas desta série interpelam o leitor destacando que possuir os carros anunciados proporciona status social, e, ligada ao status, está também a questão do estilo, como pudemos observar em:

"Comunicado importante: você está podendo". (propaganda 04)

"Com muito conforto e estilo, ela [a moto Honda] vem com largas pedaleiras [...]" (propaganda 08)

"Na vida, você precisa de força para chegar cada vez mais longe. E de elegância, para chegar lá em grande estilo". (propaganda 07)

Em "você está podendo" temos o "você" como marca da enunciação que indica o leitor da propaganda. O emprego da segunda pessoa do singular, neste caso, indica a afirmação de poder, de exaltação e de incentivo. Lembramos aqui do "Yes, you can" (Sim, você pode), enunciado proferido pelo presidente americano Barack Obama.

O uso do imperativo nas propagandas se deve à interpelação ideológica, que faz parte do complexo social, não dependendo, pois, da intenção do sujeito que elaborou o anúncio. Assim, o imperativo também se constitui numa marca lingüística da individualização do sujeito. O modo imperativo do verbo indica um chamado, um convite que se dirige individualmente aos leitores-virtuais, que são também consumidores em potencial. Podemos dizer, ainda, que o imperativo tem como propriedades fazer poder, fazer crer, fazer conhecer, fazer agir, fazer falar etc.

“Seja dono do seu destino".

"Venha conhecer".

"Faça um test drive". 
"Veja o mundo de cima".

"Dirija esse prazer".

"Tenha mais histórias para contar".

No mundo contemporâneo, que vive sob o domínio ideológico do capitalismo, o que não faltam são opções de compra. Dada tamanha oferta de produtos, não basta ser mais um no mercado, mas tem de haver um diferencial no produto ou no serviço prestado. Neste sentido, as propagandas desta série buscam diferenciar seus produtos dos demais, gerar curiosidade, e uma identificação com o leitor, como em:

"Mais que um carro". (propaganda 04)

“O poder de surpreender". (propaganda 05)

"Você nunca pilotou nada igual". (propaganda 08)

Destacamos que a relação sujeito e objeto - em nosso caso, o leitor-virtual e o que está sendo anunciado na revista - que se dá mediada pelo imaginário e pelo simbólico. A respeito da diferenciação do produto em relação a seus concorrentes, concordamos com Carrozza (2010, p. 42), quando este afirma que

Pelas técnicas da publicidade, cada vez mais se diz que é importante dar ao produto seu diferencial e, como hoje o acesso às tecnologias está cada vez mais fácil às empresas, este diferencial não pode se restringir a um atributo físico do produto. Por isso, 'agregar valor' é a palavra de ordem, no sentido de aproximar a marca a um determinado conceito ou idéia que tenha, dentro do que pode ser considerado, força de venda.

Quanto ao uso de palavras ou expressões polissêmicas, tão comuns em textos propagandísticos, ressaltamos, nesta série:

"Na vida, você precisa de força para chegar cada vez mais longe [...]" (propaganda 07)

“O 4x4 para você ir mais longe". (propaganda 06)

Há, nestes enunciados, um duplo sentido tanto do verbo "chegar" quanto do verbo "ir", havendo, pois, duas interpretações possíveis. A primeira se refere a chegar/ir mais 
longe como distância percorrida; e a segunda tem o sentido de "dar-se bem", chegar em posição social de prestígio. Temos, assim, dois planos discursivos: o da realidade cotidiana e o do "mundo do sucesso", ou, dito de outro modo, do sonho e da realidade.

Relacionando agora o verbal e o não-verbal, vemos que em ambos, nesta série, há o atravessamento do discurso ecológico, discurso com grande circulação na atualidade devido à grande preocupação mundial com o meio ambiente. No anúncio da Toyota, o carro não está numa rua ou rodovia - como se poderia esperar - mas sobre a grama e com muitas árvores ao seu redor. Quanto às marcas lingüísticas, encontramos "ar condicionado ecológico" no texto da Kia Motors. O discurso ecológico representa uma aliança do discurso jurídico com o discurso econômico, no sentido de que para que haja desenvolvimento (econômico), e para que se viva com mais qualidade, tem de haver uma preocupação constante com as questões ambientais do planeta. Desta maneira, é de responsabilidade de todos - e de cada um praticar o que se convencionou chamar de "ecologicamente correto". Nesse contexto, as montadoras Kia e Toyota mostram comprometimento com as questões ambientais. Discorrendo sobre a relação do discurso ecológico com o conceito de cidadania, Carrozza (2010, p. 38) nos diz que

\footnotetext{
atualmente, é grande o número de campanhas de produtos que visam mostrar sua preocupação com o meio ambiente, por exemplo, ou com a educação, ou com a tão falada sustentabilidade ou com o desenvolvimento sustentável, expressões estas que imprimem uma certa realidade à ilusão do sucesso capitalista, justamente por mobilizarem 'ideais' relacionados a um certo efeito de cidadania.
}

Destacamos ainda, nesta série, o uso de palavras de origem inglesa (air bag, bizone, changer, test drive, player, spoiler, etc.) que nos remetem ao discurso da globalização, da tecnologia, da praticidade. Além disso, nos parece que o uso dos estrangeirismos "agrega valor" ao produto, dando a este uma pretensa sofisticação. Por outro lado, o português é a 
língua que individualiza, que possibilita a identificação do leitor com o produto ou o serviço anunciado.

\subsection{Série Serviços}

Esta série reúne quatro propagandas (da 09 a 12), sendo duas delas da seguradora SulAmérca, uma da escola de idiomas Wizard, e a outra da operadora de cartões de crédito Visa. A seguradora apresenta um de seus segmentos: um seguro de automóveis voltado para o público feminino.

O anúncio da escola de idiomas Wizard foi publicado na Veja de 17/07/08. A data faz parte das condições de produção do texto, porque é geralmente nos meses de férias escolares, como Julho, em que as escolas (não só as de idiomas) “investem pesado" em conseguir novos alunos para o próximo período letivo.

O anúncio traz como garotos-propaganda os alpinistas Rodrigo Raineri e Eduardo Kepple, que conseguiram chegar, literalmente, ao "topo do mundo", pois chegaram ao cume do Monte Everest, considerado o ponto mais alto do planeta. Para alcançar seu intento, os alpinistas "acreditaram em si mesmos, acreditaram em seu sonho e alcançaram o topo do mundo", contando com o patrocínio da Wizard. Esta, por sua vez, se auto-intitula "a maior rede de ensino de idiomas do país". Na foto, a dupla, no alto da referida montanha, segura uma faixa onde se lê "Wizard". Neste anúncio, assim, o verbal e o imagético estão imbricados, funcionando conjuntamente na produção de sentidos.

Em "acreditaram em si mesmos" temos a marca da individualização, o pronome reflexivo "si", reafirmado por co-referência pelo "mesmo". Quanto à pronominalização, observamos ainda "seu sonho", "você no topo do mundo", "Você faz", Você vence". Além disso, funciona aí um discurso do sucesso, que desfruta de grande 
circulação social na contemporaneidade. Como explica Orlandi (2007, p.16) “é preciso fazer o próprio lugar para ser reconhecido, tornar-se vendedor da própria vida”. Para que se alcance esse objetivo, há necessidade de "acreditar em si mesmo". A propaganda busca, assim, atender às necessidades individuais.

Vemos funcionar na propaganda da Wizard (e não somente nela) a relação entre o desejo e a ideologia, que retomaremos no final do dissertação. Se nos voltarmos para a sociedade em que vivemos, aprender uma língua estrangeira, em especial o inglês, é tido como fundamental, como condição para que o sujeito consiga entrar ou se manter no mercado de trabalho. Dessa forma, todos necessitariam aprender o inglês para "sobreviver" neste mundo globalizado. Assim, as práticas sociais vão produzindo as condições de produção do discurso e a evidência dos sentidos que a propaganda faz circular socialmente.

A propaganda da escola de idiomas trabalha a evidência do real e dos sentidos, tanto na materialidade verbal quanto na não-verbal. Em "A Wizard realiza seus sonhos" temos novamente a questão do sonho (como já mencionado na análise da série Turismo) e quão importante e estimulante ela é para o sujeito. A Wizard, então, seria o "agente realizador" do sonho, tanto de seus patrocinados, os alpinistas, quanto desse "você" a quem se destina a propaganda. Para nossa perspectiva teórica, o sonho é pensado como um funcionamento do imaginário, mas não podemos esquecer que, mesmo quando fala sobre o sonho a empresa tem objetivos concretos, que são levar o sujeito a consumir e produzir identificação com o provável consumidor. Para que se identifique com a marca, o produto, ou o serviço ali anunciado, a empresa individualiza esse leitor-virtual, dando um efeito de que o anúncio é dirigido exclusivamente àquele leitor.

Nesta direção, observamos também o slogan da empresa "Você faz. Você vence" o slogan traz em seu funcionamento a sustentação pela forma-sujeito contemporânea, "o sujeito livre para que livremente se assujeite", como nos diria Pêcheux. Temos, nesta 
propaganda, um sujeito que escolhe e que, portanto, se identifica com a forma-sujeito contemporânea. Ademais, as propagandas das escolas de idiomas trabalham com o imaginário sobre o aprendizado de línguas estrangeiras, com destaque para o inglês, mostrando como evidente que tal aprendizado leva ao sucesso profissional. Estas instituições de ensino seriam, dessa forma, um caminho necessário a se percorrer para chegar "ao topo do mundo". Aliás, o enunciado "você no topo do mundo" é polissêmico, uma vez que pode se referir tanto aos esportistas apresentados (alpinistas), quanto à possibilidade desse leitor individualizado alcançar "o topo do mundo", ou seja, vencer profissionalmente e ter seu mérito reconhecido pela sociedade.

A propaganda do cartão de crédito Visa, por seu turno, relaciona o texto com a imagem e trabalha atentamente a forma-sujeito atual, o sujeito de direito, responsável e ao mesmo tempo dono de sua vontade. A relação lingüístico-imagético se dá com a colocação de imagens de comida que se relacionam a "restaurante", "almoçar" e "jantar".

O anúncio incide em especial sobre a livre circulação social e sobre o sujeito como "senhor" de sua vontade. Neste contexto, percebemos "você usa seu cartão em qualquer restaurante", "almoçar ou jantar onde quiser", "restaurante à sua escolha", "qualquer restaurante". Os enunciados apresentam diversas possibilidades aos leitores que, de posse do cartão, teriam várias opções à sua escolha.

As sequências "onde você quiser" e "à sua escolha" nos dão pistas da individualidade do sujeito, que vai onde deseja e é dono de sua vontade, podendo exercê-la de várias formas. O cartão Visa, então, viabilizaria a realização dos desejos desses sujeitos. Pensamos aqui novamente na noção de sujeito desejante, como já exposto no capítulo primeiro. O ato de consumir, enquanto gesto simbólico e individual (CARROZZA,2010) seria uma das formas de suprir as lacunas do sujeito, mas temporariamente, já que o sujeito, como compreendido pela psicanálise, é sempre faltante ou desejante. O desejo, algo sempre latente 
no sujeito, é pensado na $\mathrm{AD}$ não como tendo cunho biológico ou psíquico, mas, antes, como sendo historicamente construído.

Em "Visa, porque a vida é agora", slogan do anúncio, observa-se a conjunção "porque" introduzindo uma justificativa para o uso do cartão. Se pensarmos que está implícito um use antes de "Visa" - (use) Visa -, podemos dizer que "Porque a vida é agora" interpela o leitor, instaurando um "fazer agir", que se daria na temporalidade "agora", isto é, no momento da interlocução. O enunciado supracitado nos faz lembrar ainda do "carpe diem" ou "aproveitar o dia", tema de muitos textos literários. A expressão latina esteve presente em especial no período literário conhecido como Arcadismo, e tem como mote o deleite dos momentos que a vida proporciona, devido à incerteza que o futuro traz ao indivíduo. Isso também se aplica à atualidade, marcada pela fluidez nos mais diversos segmentos da vida em sociedade. No verbete da Wikipedia ${ }^{4}$ estabeleceu-se uma relação entre o carpe diem, a mídia e a sociedade atual, onde se lê que "[...] viver o hoje e não se preocupar com o amanhã é um estilo de vida largamente difundido pela mídia e atrelado aos valores do consumismo e materialismo como meios de obtenção do prazer".

As duas propagandas restantes são da seguradora SulAmérica, e se destinam a um público bem específico, as mulheres. O processo de individualização, assim, ocorre com um grupo, as mulheres, buscando a identificação deste com os serviços oferecidos pela seguradora. Afirmamos, com base em nosso corpus, que o processo de individualização pode ocorrer com indivíduos e com grupo. No primeiro caso, a interpelação é um processo que constitui o sujeito por dar a ele a "evidência de sua identidade" (ORLANDI, 2008, p. 101), a ilusão da origem de si, resultando num sujeito que pensa ser dono de sua vontade; no segundo caso, evoca o desejo (e a necessidade) que o sujeito tem de pertencer a um grupo e estabelecer

\footnotetext{
${ }^{4}$ http://pt.wikipedia.org. Acesso em 25 de Junho de 2010.
} 
laços sociais (cf. Orlandi, 2006a). Optamos por analisar estes dois anúncios conjuntamente, por serem da mesma seguradora e, mais decisivamente, pela similaridade entre eles.

Ambos os anúncios trabalham com o imaginário sobre as mulheres, trazendo à tona a questão do estereótipo. Para a AD, os estereótipos são historicamente construídos, bem como são resultantes de um trabalho da ideologia. Quando os sentidos são tomados como evidentes, caso dos estereótipos, o imaginário está funcionando de modo pleno. Falando sobre o funcionamento ideológico, Pêcheux (1995, p. 160) salienta que

É a ideologia que fornece as evidências pelas quais 'todo mundo sabe' o que é um soldado, um operário, um patrão, uma fábrica, uma greve, etc., evidências que fazem com que uma palavra ou um enunciado 'queiram dizer o que realmente dizem' e que mascaram, assim, sob a 'transparência da linguagem' aquilo que chamaremos o caráter material do sentido das palavras e dos enunciados.

Segundo o que expõe Pêcheux, podemos afirmar que, nestes anúncios, a ideologia fornece a quem os elaborou, as pistas de quem são as mulheres, do que gostam, do que necessitam, etc. Ressalta-se que o próprio texto esclarece que o serviço oferecido, o seguro de automóveis, foi "pensado por mulheres e para mulheres". Neste caso, teríamos, na materialidade do anúncio, uma imagem do que as mulheres pensam e esperam de e para si mesmas. Quanto ainda à questão da estereotipia, ligada ao imaginário, destacamos os enunciados:

"Mais segurança e proteção" (propagandas 11 e 12)

"Em caso de roubo ou furto, um acompanhante vai com você até a delegacia" (grifo meu, propagandas 11 e 12)

“Após a meia-noite, o Motorista Amigo leva você até a sua casa". (grifo meu, idem)

Diferentemente da propaganda da série Turismo em que se tinha a imagem da mulher independente, estes anúncios da SulAmérica abrem duas possibilidades de 
interpretação: mostram a mulher como "sexo frágil”, aquele que necessita de proteção, de segurança e que não deve andar desacompanhado, por isso a seguradora oferece "um acompanhante" e um "motorista amigo"; e de outro lado a mulher que dirige e que tem condições financeiras de contratar o seguro oferecido. Os dois textos propagandísticos da seguradora trabalham com a possibilidade do equívoco, com a contradição: a mulher como "sexo frágil" e a mulher dominante, que usa a fragilidade a seu favor, já que "quem tem que suar são os homens”. No segundo caso, vemos aí um discurso pós-feminista, segundo o qual a mulher conquistou uma posição social que a torna independente dos homens, em diversos aspectos. Vale ressaltar que o equivoco para a $\mathrm{AD}$ se refere à inscrição da língua na história, a historicidade dos sentidos, pois, é o que pauta e possibilita o equívoco.

Observamos ainda, nestas propagandas, que estes mesmos enunciados funcionam como uma tentativa de proximidade com o leitor, ou melhor, a leitora. Além do pronome de tratamento "você" que individualiza e faz parte do discurso cotidiano, “acompanhante" e "amigo" são marcas dessa tentativa de proximidade e identificação. Em "central exclusiva de atendimento" (grifo meu) temos outra marca lingüística do processo de individualização, marca esta que possibilita ao sujeito sentir-se único, importante, exclusivo. Este processo, então, incide diretamente na subjetividade e viabilizada a identificação deste leitor-ideal com o que está sendo oferecido para compra.

No que se refere à relação verbal e não-verbal, podemos afirmar que nestes anúncios eles funcionam conjuntamente, relacionando, pois, a imagem e o texto. Em uma propaganda temos a foto de uma sandália de salto alto e o enunciado "Não deixa você a pé porque sabe que você anda de salto alto". No outro, observa-se um frasco de perfume e a sequência "Porque quem tem que suar são os homens".

A conjunção "porque" - como já vimos na análise do cartão Visa - introduz uma justificativa. Neste caso, justifica-se a contratação e utilização dos serviços prestados 
pela SulAmérica. Nos dois enunciados ("porque sabe que você anda se salto alto" e "Porque quem tem que suar são os homens”) ressaltamos o efeito de pré-construído. Assim sendo, do modo como foram colocados, os enunciados estariam fora do escopo de negação. Mesmo que se negasse o verbo saber (porque não sabe) o pré-construído de que as mulheres andam de salto alto se manteria. Os sentidos presentes nos anúncios, da forma como são postos, se mostram como evidentes, construindo a imagem do leitor. No caso destes textos propagandísticos, o mecanismo de antecipação, como o expusemos na parte teórica, funcionou pautado pelo funcionamento imaginário. Ousamos dizer que se o seguro foi pensado "por mulheres e para mulheres" elas mesmas foram atravessadas pelo imaginário que circula socialmente sobre as mulheres. Segundo as propagandas da SulAmérica, há um discurso do poder envolvido, um jogo de posições e um modo de enxergar o outro, atravessado, sempre, pelo imaginário. Observamos ainda um embate de posições, a machista, que toma a mulher como "frágil" (que necessita de "mais segurança e proteção"); e a feminista, que vê a mulher como independente e que usa sua condição de mulher a seu próprio favor, já que "quem tem que suar são os homens".

\subsection{Série Cuidados pessoais}

Para esta série temática (propagandas 13 a 16), selecionamos quatro anúncios: um dos iogurtes Batavo (empresa que comercializa gêneros alimentícios); um da linha Johnson's Baby (produtos de higiene e cuidado pessoal voltado para o público infantil) da Johnson's \& Johnson's; um da Avon (empresa de cosméticos que vende seus produtos por catálogos e pela internet) e o último da Lojas Renner (loja de departamentos presente em todo Brasil). 
O anúncio da Batavo, mais especificamente da linha "Pense Light", traz como garota-propaganda a modelo, apresentadora e empresária Ana Hickmann. Esta é tida como um símbolo de beleza, de boa-forma e de sucesso, nas diferentes áreas em que atua. Ela aparece, por assim dizer, como um "modelo" de beleza, com o qual as mulheres, consumidoras da Batavo, buscariam identificar-se. Nesse sentido, podemos afirmar que a propaganda dos iogurtes Batavo individualiza a mulher pela identificação. A esse respeito citamos novamente Carrozza (2010, p. 59), para o qual

Cria-se, dessa forma, uma ciranda de imaginários, onde se configura um jogo produtivo entre reconhecer/conhecer/ser o nível da representação, quando, na verdade, o que se faz é construir um consumidor com o qual os sujeitos se identifiquem e desejam ser.

Assim é que a publicidade, funcionando no nível imaginário que constitui sua relação com a sociedade se apresenta tendo como objetivo primeiro informar sobre produtos que estão no mercado. E, fazendo isso, produz sentidos sobre o cotidiano, na própria relação com os sujeitos aí identificados como consumidores.

Se voltarmos nossa atenção para o complexo social em que estamos inseridos, ou seja, para as condições de produção amplas do discurso, poderemos relacioná-la a esta propaganda em termos de que a busca incessante pela boa-forma física e pela boa aparência constituem uma verdadeira "ditadura da beleza" para a mulher atualmente. Está aí, pois, o funcionamento de uma formação imaginária segundo a qual a mulher deve manter-se sempre jovem, atraente, com a silhueta esguia e atenta às últimas tendências da moda e dos cuidados com o corpo. Para o psicanalista Joel Birman (2005, p. 08) “o corpo é sem dúvida o registro no qual o sujeito se reconhece hoje na sua máxima vulnerabilidade. [...] Por isso mesmo, a saúde é perseguida de maneira ostensiva, se transformando então no bem supremo do sujeito contemporâneo". 
Observamos também neste anúncio o discurso da medicina, segundo o qual deve-se consumir menos açúcar e menos gordura para se ter uma vida mais longa e saudável, por isso os iogurtes da "Pense Light" têm "zero adição de açúcar" e "0\% de gordura".

O slogan "De bem com você" explicita que os produtos anunciados têm como proposta atender às necessidades individuais daqueles que buscam uma alimentação mais saudável. "De bem com" pode ser compreendido como em consonância, aquele que entende, que está de acordo. Assim sendo, os produtos "Pense Light" cumpririam às exigências deste consumidor, estando "de bem com" ele.

No que tange à enunciação, vemos no slogan um enunciador coletivo (Nós estamos "de bem com você"), que fala da posição da empresa Batavo e se dirige a um "você", individualizado enquanto leitor-virtual e potencial comprador dos produtos. Outra leitura possível do slogan, já que o mesmo constitui-se numa oração sem sujeito, é a de que o leitor está “de bem" consigo mesmo (você "de bem com você"), tratando-se, então, de um enunciado com duplo sentido. Identificamos, ainda, o modo imperativo do verbo ("viva" e "pense") como marca lingüística do processo de individualização do sujeito presente na enunciação.

Atentamos também para o deslizamento de sentido em "Viva Leve. Pense Light", no qual há uma relação parafrástica entre "leve" e light". O emprego de palavras de língua inglesa nos remetem, como já mencionamos, ao discurso da globalização, da tecnologia e da praticidade, imprimindo um pretendo refinamento e sofisticação ao produto que se dão no plano do imaginário - mesmo que este produto seja nacional. "Viva Leve" também traz como pré-construído "viva sem estresse".

Esta propaganda é ainda atravessada pelo discurso ecológico, já que Ana Hickmann, a garota-propaganda, está deitada sobre a grama, numa posição que remete ao descanso, ao relaxamento e à contemplação. Ousamos dizer que "light" ou "leve" também se 
relaciona com a imagem, uma vez que o imaginário contemporâneo propaga que ter contato com a natureza corresponderia a ter uma vida mais saudável e menos estressante, ou seja, uma vida mais "light". André Dalben (2009) considera que "a natureza é um lugar de fruição" para os sujeitos, sendo que estes desfrutam de prazer em contato com as paisagens naturais.

Entendemos que neste anúncio da Batavo o discurso ecológico e o discurso da medicina estão "associados", juntamente com o que chamaremos discurso sobre a beleza. Conforme esboçamos, o enunciado "Viva Leve. Pense Light" interpela o leitor nestas três direções respectivamente, ou seja, ter uma alimentação mais saudável; ter mais contato com a natureza, vivendo de modo mais "light"; e consumir produtos light para ter uma silhueta esbelta, em consonância com os padrões de beleza tidos como ideais atualmente.

O anúncio da Johnson's Baby apresenta ao leitor a foto de uma jovem segurando um bebê, e afirma que se destina a homenagear as mães. A data da publicação (14/05/08) faz parte das condições de produção do texto, já que foi publicado logo após o segundo domingo do mês de maio daquele ano, o Dia das Mães. Para o comércio, esta é a segunda melhor data comemorativa para as vendas, perdendo apenas para o Natal.

Ressaltamos, ainda, que o objeto da prática publicitária é o presente, a conjuntura atual. Mesmo sendo uma homenagem ao Dia das Mães, a propaganda não apresenta uma família tradicional (pai, mãe e filho), mas uma mulher sozinha com seu bebê, individualizada. Recorrendo às condições de produção, isso novamente traz à tona, como em outras propagandas, a questão da mulher independente, que assume sozinha a responsabilidade de ser mãe. Pensando na contradição, poderíamos dizer que neste anúncio além da imagem da mulher, como a expusemos, há ainda a imagem da maternidade.

A interpelação acontece individualmente sobre a mulher, que "tem que aprender a ser mãe". A posição a partir da qual a empresa Johnson's se apresenta, a coloca como aquela que auxilia a mãe nos cuidados com a criança, oferecendo "a linha mais 
completa para cuidar do seu bebê”. Esta posição se mostra ainda mais como evidente em "você sabe que pode contar com a gente".

Esta propaganda, embora se dirija a um grupo bem delimitado, produz uma "escuta individual" (CARROZZA, 2010, p. 134), tendo como leitor-virtual as mulheres que tiveram filhos recentemente. No enunciado "Quando nasce um bebê, nasce também uma mãe", o advérbio "quando" introduz uma relação de simultaneidade entre os fatos - o nascimento do bebê e o tornar-se mãe. Esta relação é retomada e reforçada pela foto do anúncio. De novo, verbal e não-verbal funcionam conjuntamente na produção de sentidos.

Quanto à pronominalização, temos novamente o "você", que, neste caso, individualiza as mulheres que tornaram-se mães recentemente, e também os possessivos "seu" (“ao seu lado") e "seus" (“seus primeiros passos como mãe”) que também individualizam.

Em "você sabe que pode contar com a gente" observamos o enunciador coletivo “a gente" que fala da posição social da empresa Johnson's \& Johnson's e se dirige a um sujeito individualizado, designado por "você".

A terceira propaganda da série é da empresa de cosméticos Avon, que apresenta o perfume Signature, um lançamento na época da publicação. Sabemos que se trata de um perfume voltado ao público masculino porque na primeira página do anúncio está o ator Alexandre Borges. Este tem uma carreira consolidada, trabalhando na televisão, no teatro e no cinema brasileiros.

A propaganda da Avon tem como não-verbal a foto do ator (individualizado) e a do perfume. Borges está sentado e sorridente, com uma caneta na mão, como que prestes a assinar algum papel. Mostrando o ator na propaganda, buscou-se uma identificação do leitor com ele e também com o que está sendo anunciado, o Signature.

O próprio nome do perfume, "Signature", se relaciona ao enunciado "Avon International", nos remetendo, como já visto antes, ao discurso da globalização. Nesse 
sentido, o inglês é a língua que possibilitaria a comunicação em diversas partes do globo, como "Paris, New York e Tokyo". Apontamos, ainda, uma relação de paráfrase entre "signature" e "assinatura", sendo esta a tradução daquela para a língua portuguesa.

O perfume é apresentado como "seu estilo, sua marca, sua assinatura". A individualização deixa suas pistas na pronominalização, com o uso dos possessivos "seu" e "sua". Os possessivos, como já diz a designação, indica a pertença de alguma coisa a alguém. E este alguém, o leitor, é produzido em sua individualidade pelo anúncio. O perfume Signature, segundo a propaganda, viabilizaria ao leitor "deixar marcas" de sua individualidade, já que o uso do perfume expressaria o estilo do sujeito, deixando "no ar" "sua marca e sua assinatura". Questionamos: haveria algo mais individualizante para o sujeito do que sua própria assinatura? Com efeito, a assinatura, por mais que se tente imitar, é algo único, pessoal e intransferível de cada sujeito.

A quarta e última propaganda da série é a da Lojas Renner. Nela, uma jovem não identificada, está usando um vestido de festa e envolta em uma faixa na qual se lê "Você tem seu estilo. A Renner tem todos." Este é o slogan da Renner, do qual trataremos mais adiante.

Faz parte das condições de produção do texto o fato de o mesmo ter sido publicado em uma edição especial da Veja, intitulada "Edição Especial Veja Mulher", publicada em 28/05/08. De acordo com o site da Veja, há "Projetos Publicitários Especiais", dentre os quais os chamados "Cadernos Especiais Temáticos", que são publicados nas principais datas comemorativas brasileiras.

Segundo o anúncio, ele consistiria numa homenagem das Lojas Renner "a todas vocês, mulheres de verdade”. Este enunciado individualiza não somente um sujeito, mas um grupo, tendo como marca da enunciação "vocês" (e não "você”). A individualização do grupo propicia ao sujeito o sentimento de pertencimento. Inserido em um grupo, o sujeito tem 
o sentimento de pertencer também a uma sociedade. A esse "vocês", de acordo com a propaganda, corresponderiam todas as "mulheres de verdade". Estabelece-se, deste modo, uma relação entre o dito e o não-dito.

Para a AD, o que não é dito, mas que fica subentendido no dizer, é considerado como constitutivo deste próprio dizer, fazendo-o significar. Orlandi (2001, p. 82) esclarece que "ao longo do dizer, há toda uma margem de não-ditos que também significam." Voltando para a propaganda da Renner, afirmamos que às "mulheres de verdade" corresponderiam as interlocutoras do anúncio, o "vocês". Fica como não-dito que existem "mulheres de mentira". Mas quem seriam elas?

No funcionamento do anúncio, pudemos observar que as "mulheres de verdade" são aquelas que não dão autógrafos, não aparecem na TV, mas que têm muitos fãs, embora não saibam explicar o motivo de tal fato. Com base nisso, podemos afirmar que "mulheres de verdade" são aqueles que não pertencem "ao mundo das celebridades", que são mulheres anônimas e desconhecidas como a moça que aparece no anúncio. É com essa suposta "mulher de verdade" que a propaganda espera que sua leitora se identifique. O advérbio "nunca" nega os verbos dar ("nunca deu autógrafos"), aparecer ("Nunca apareceu na TV") e saber ("Nunca soube explicar"), colocando esses enunciados como condições necessárias para que a jovem tivesse fãs. Na sequência temos "e nunca soube explicar por que tem tantos fãs". Este enunciado é controverso ao que vem anteriormente, e tem no "por que" (que equivale a razão, motivo) a introdução da explicação que se opõe ao que foi dito antes.

No corpo do texto, o anúncio tem a marca lingüística da individualização do grupo ("vocês"), mas no slogan "Você tem seu estilo. A Renner tem todos", observamos as marcas do processo de individualização do sujeito ("você", "seu”). Há, dessa forma, um jogo entre o processo que incide sobre a individualidade e o outro que incide no desejo de 
pertencimento a um grupo. No slogan existe ainda uma elipse "A Renner tem todos (os estilos)", que enfatiza possibilidade de escolha que a loja proporciona, bem como a questão da importância de se ter um estilo para o sujeito, o que aliás aparece como um pré-construído, ou seja, como se cada um tivesse seu estilo.

\subsection{Série Tecnologia}

Esta série temática é composta por quatro propagandas (da 17 a 20): uma da Itautec, uma da Dell, uma da Intel e uma da operadora de telefonia celular Vivo.

Uma das regularidades encontradas é a presença somente de fotos de homens nos anúncios, excetuando-se o da Vivo no qual somente aparece a foto do aparelho comercializado. Embora o anúncio se destine a todos (homens e mulheres), o que prevalece é a imagem do homem. A imagem masculina está, então, nestes anúncios, relacionada à tecnologia. A escolha dos homens nestas propagandas se refere a uma seleção que, por sua vez, se relaciona ao funcionamento ideológico, da ordem do esquecimento número dois (Pêcheux). Falando sobre os conceitos formulados por Pêcheux (os esquecimentos número um e número dois) Orlandi (2001, p. 35) esclarece

este 'esquecimento' [o número dois] produz em nós a impressão de realidade do pensamento. Essa impressão que é denominada ilusão referencial, nos faz acreditar que há uma relação direta entre o pensamento, a linguagem e o mundo, de tal modo que pensamos que o que dizemos só pode ser dito com aquelas palavras e não outras, que só pode ser assim. Ela estabelece uma relação 'natural' entre palavra e coisa.

Como, neste ponto, estamos tratando do não-verbal - as fotos de homens nos anúncios da série - deslocamos o conceito para o imagético, afirmando que essa "ilusão referencial" se deu com a colocação de somente figuras masculinas, isto é, foi estabelecida 
pelos publicitários uma relação entre homens e tecnologia, como se tal relação só pudesse ser dessa maneira.

A presença da mulher nesses setores, embora na realidade seja latente, é silenciada nestas propagandas. Vemos aí a imagem do público que se almejava interpelar quando da elaboração dos anúncios e, a ausência da figura feminina nos aponta que a mulher, enquanto imagem com a qual se deseja identificação, não faz parte deste público-alvo. O que o publicitário e as empresas buscam, pensamos, é gerar uma identificação com o público masculino.

Quanto às condições de produção, fomos procurar quem eram essas empresas para melhor entendermos o funcionamento discursivo de suas propagandas. Encontramos informações de cada uma delas no site da Wikipédia ${ }^{5}$, uma enciclopédia virtual.

A Itautec, segundo o site consultado, é uma empresa nacional, e faz parte do grupo Itaúsa - Investimentos Itaú S. A. Esta empresa especializou-se em desenvolvimento de soluções em informática e automação de serviços, atuando tanto no setor corporativo quanto no doméstico. Os computadores da empresa são comercializados com a marca Itautec. De imediato, a marca dos computadores nos faz lembrar do banco Itaú. Essa filiação de sentido agrega confiabilidade à marca de computadores, já que o Banco Itaú é um dos maiores e mais tradicionais do Brasil.

A propaganda da Itautec apresenta ofertas de computadores (dois notebooks e um desktop), elencando detalhadamente as características de cada produto e mostrando o preço dos mesmos. Em destaque na página está um indivíduo desconhecido, jovem e bem vestido, que lembra um executivo. A este jovem atribuem o enunciado "Depois da era da tecnologia e da informação, vem aí a era da tecnologia personalizada". É apresentado ao leitor um passado já superado, que tem como marca esse "depois", que se contrapõe ao "vem aî",

\footnotetext{
${ }^{5}$ (http://pt..wikipedia.org)
} 
que funciona como um presente com latência de futuro. Temos aí a marca linguística de um discurso que aponta para a futuridade: o imaginário contemporâneo contempla o futuro, em termos de tecnologia, como o que terá objetos melhores, mais sofisticados, mais automatizados e, segundo o anúncio, mais personalizados. "Personalizados" faz referência a uma configuração dos computadores que atende à necessidade de cada cliente. A propaganda da Itautec mostra-se, pois, ligada ao processo de produção, sendo ambos, a produção e a propaganda, individualizantes. A empresa busca, assim, atender e satisfazer necessidades individuais. Portanto, as marcas lingüísticas da individualização neste anúncio ficam por conta de "personalizada" e "personalização", palavras que atingem a subjetividade do leitor. Quanto ao não-verbal, o rapaz encontra-se sozinho e em destaque na propaganda da Itautec.

Observamos ainda no anúncio um símbolo sob o qual se lê "Compromisso com a sustentabilidade". Podemos novamente afirmar que o discurso publicitário, em uma materialidade específica - a propaganda impressa - é atravessado pelo discurso ecológico. Com esse discurso também se busca uma identificação com um leitor consciente das causas ambientais. Ao adquirir um produto fabricado por uma empresa comprometida com a sustentabilidade do planeta, o consumidor estaria fazendo um consumo consciente e, ao mesmo tempo, exercendo sua cidadania, já que, hoje em dia, ser consciente é ser cidadão. Fica claro, então, que o consumo deve ser pensado enquanto gesto simbólico (CARROZZA, 2010), e que, o ato da compra em si é mediado tanto pelo simbólico quanto pelo imaginário.

A propaganda da Intel ( sigla de Integrated Eletronics Corporation) traz a foto do corretor financeiro Sérgio Aun. A colocação da posição social dele, que é a de corretor financeiro, vem reafirmar o que dissemos no início sobre a relação, como colocada pelas propagandas da série tecnologia, entre o mundo dos negócios, a tecnologia e a posição dos homens nessas áreas. 
O corretor financeiro aparece sentado com um notebook no colo, segurando um processador "Intel Centrino", um dispositivo que fornece ao usuário uma conexão sem fio com a internet no notebook. A Intel, aliás, é uma empresa multinacional de origem americana fabricante, dentre outros produtos, de microprocessadores. Fizemos questão de fazer essas considerações porque na foto não é mostrada a marca do notebook que o rapaz está usando, o que se justifica na medida em que, se a empresa produz microprocessadores o foco deveria ser o processador" Intel Centrino" e não o equipamento, o computador. O fato de ser multinacional também se relaciona ao enunciado "Hoje, meu concorrente é o mundo inteiro" (grifo meu). Esta afirmação, proferida pelo corretor financeiro, diz respeito e ele mesmo e à própria empresa Intel. Na mesma direção, temos "Se eu tiver um Intel Centrino no notebook, estou conectado em qualquer parte do planeta" (grifo meu), já que num mundo dos negócios globalizado, inserido em um mercado altamente competitivo, "estar conectado" significa mais oportunidades de negócios e, consequentemente, de mais lucros. As palavras grifadas constituem pistas do discurso da globalização, que constantemente atravessa o discurso publicitário.

Quanto à temporalização, temos "Hoje", um advérbio de tempo que funciona como operador argumentativo, apontando para a atualidade, para o momento da interlocução. A repetição de "você merece" é um enunciado individualizante, e interpela o leitor a se permitir comprar o que está sendo anunciado, independentemente se tem condições financeiras de adquirir o produto.

O quarto anúncio da série é o da Dell, grande empresa americana que fabrica e comercializa variados tipos de computadores, em especial os notebooks. Assim como na propaganda da Itautec, a da Dell apresenta os produtos de sua marca com suas características e preços. 
O enunciado principal "Ele acompanha você em tudo. Até no seu jeito de ser" se relaciona com a imagem. A foto aparece centralizada e na tela de um notebook da Dell. Nela, um jovem sorridente está sentado sozinho numa mesa de lanchonete, cujo ambiente aparece atrás dele. O rapaz está diante de um notebook da Dell, diríamos, "acompanhado" por ele. Nesse sentido, o computador, sendo portátil, pode ser carregado para onde vá seu usuário. "Acompanha" é marca do discurso da mobilidade, um dos anseios do sujeito contemporâneo, que se desloca para todos os lugares e o faz rapidamente, precisando, principalmente por causa de trabalho, "estar sempre conectado". A marca Dell, então, supriria esse anseio do sujeito, oferecendo a ele a possibilidade de locomover-se e levar consigo seu computador.

"Compre o seu Dell do seu jeito" e "Compre a qualquer dia e hora" (grifos meus) interpelam pela individualização, tendo no imperativo e na pronominalização "seu" as marcas lingüísticas deste processo.

O slogan "Dell, yours is here" (“O seu está aqui", tradução minha) faz referência à imagem do notebook da marca. Se tomarmos como implícito "computador" antes de Dell (Computador "Dell, o seu está aqui”), o “yours" (“seu”) retoma computador por coreferência.

A propaganda da Vivo não apresenta figuras humanas, mas optou-se por destacar o aparelho que está sendo anunciado, enfatizando suas características e vantagens frente aos produtos concorrentes. Os desenhos ao redor do aparelho indicam o que o Palm Centro da Vivo faz, como "acesso a e-mails e internet", "Visualiza e edita arquivos de Word e Excel", "Visualiza arquivos de PowerPoint e PDF". Estas características se relacionam com a primeira parte do enunciado principal "Facilita seu trabalho". Já o fato de o aparelho ter "MP3 Player" se liga a segunda parte do enunciado principal "[...] para você ter mais tempo de se divertir". Por sua composição, esta propaganda opõe "trabalho" e "diversão". Além disso, "ter 
mais tempo" é um desejo constante do sujeito atualmente, por seu excesso de ocupações, rapidez do mundo moderno, etc.

No que concerne às marcas lingüísticas da individualização, temos o "você" como interlocutor individualizado, quanto a pronominalização há "seu", além do uso do modo imperativo do verbo em "vá" e "compre".

O slogan da Vivo é "Sinal de qualidade", no qual se percebe um duplo sentido da palavra "sinal", que pode tanto se referir ao sinal do telefone quanto significar "o que indica" qualidade.

\subsection{Série Bancos}

Para esta série (propagandas 21 a 25) selecionamos três propagandas do Banco Itaú, uma do Banco do Brasil, e uma do Santander, perfazendo um total de cinco propagandas. O Itaú é um banco privado, com agências em todo o Brasil, nas Américas, na Europa e na Ásia ${ }^{6}$. O Banco do Brasil atua no Brasil e no exterior, e o Santander é um banco privado estrangeiro com agências no mundo todo, cuja sede é na Espanha ${ }^{7}$.

Notamos que nesta série há uma busca por uma identidade pelo discurso, ou seja, as instituições bancárias almejam que seus prováveis clientes se identifiquem com os serviços prestados. Mas não é só isso. Cada banco procura mostrar ao cliente-virtual um diferencial em relação às outras instituições bancárias, e além de diferenciar-se "agregar valor" (CARROZA, 2010) é palavra de ordem nas propagandas. O que percebemos, assim, é que pelos arranjos verbais e imagéticos, o anúncio individualiza pela identidade, numa busca

\footnotetext{
${ }^{6}$ In: www.itau.com.br.

${ }^{7}$ In: www. santander.com.br.
} 
constante pela aproximação com o leitor. Para tanto, os textos dizem, ao mesmo tempo, a todos e a cada um, numa aproximação imaginária e individualizante. Podemos afirmar ainda que a forma-sujeito contemporânea sustenta os dizeres dos anúncios.

O primeiro anúncio do Itaú se organiza em torno da palavra "benefício", no qual o leitor é interpelado a descobrir com qual dos benefícios oferecidos pelo banco ele se identifica. O enunciado principal "Abra uma conta e descubra qual benefício do Itaú foi feito para você”, nos dá pistas do processo de individualização do sujeito com o uso do modo imperativo do verbo e com a pronominalização "você".

A repetição de "benefício" ao longo do anúncio enfatiza a imagem que o banco e quem elaborou o anúncio - o publicitário - têm do leitor e do que ele deseja, mostrando como evidente aos leitores da revista que todos desejam ter os benefícios que o Itaú oferece. Funciona como pré-construído, neste anúncio, que o Itaú tem um "benefício" para o leitor. Vejamos:

“[...] descubra qual benefício do Itaú foi feito para você”. (grifo meu)

"Cliente Itaú tem a melhor relação custo-benefício". (grifo meu)

“Tem o benefício de contar com milhares de agências e caixas eletrônicos pelo Brasil [...]" (grifo meu)

"Benefício de ter crédito rápido para o seu dia-a-dia [...]"

"Mas benefício mesmo é ter conta num banco que vale o que custa".

"Itaú, a melhor relação custo-benefício para você".

Segundo os enunciados acima, são elencadas as facilidades - ou "benefícios" que os possíveis clientes do Itaú teriam. Mas observamos uma ênfase maior em "Mas benefício mesmo é ter conta num banco que vale o que custa", no qual a conjunção "mas" muda a direção argumentativa, ressaltando que o que foi posto antes tem menor força 
argumentativa do que o enunciado introduzido pelo "mas" afirma. Além disso, "mesmo" enfatiza e reafirma a palavra "benefício", dando ainda mais destaque a ela.

$\mathrm{O}$ adjetivo "melhor" funciona como um operador argumentativo, enfatizando a qualidade superior (em relação a outros bancos) do que está sendo apresentado, a "relação custo-benefício". O numeral "milhares" faz parte do discurso estatístico e também destacaria -e comprovaria - as facilidades que o banco está oferecendo ao leitor.

Os enunciados "melhor relação custo-benefício" e "banco que vale o que custa" se relacionam com a imagem, na qual uma jovem segura um lápis (com as cores e o logotipo do Itaú), com uma expressão facial que mistura dúvida e contentamento. Pensamos que a foto da moça traz à memória a expressão popular "pôr na ponta do lápis", fazendo referência a uma suposta "descoberta" de que o Itaú seria o banco com a "melhor relação custo-benefício" para o leitor, e possível cliente.

Ressaltamos ainda o enunciado "o $O K$ mais rápido do mercado para comprar sua casa, seu carro", no qual as palavras destacadas nos remetem ao discurso cotidiano e à rapidez do mundo atual, a qual é vivenciada pela maioria dos sujeitos no mundo contemporâneo.

A outra propaganda do Itaú mostra o serviço designado como Itaú Personnalité, segundo o qual o banco almeja "saber quem você é, entender o seu momento de vida, oferecer o benefício que você precisa. Porque só é perfeito para nós quando é perfeito para você”. Com base neste enunciado, podemos dizer que o banco Itaú se coloca na posição daquele que "entende o momento de vida" do cliente e, portanto, pode oferecer o que ele precisa "com perfeição". O "porque" - como já observamos em outros textos - introduz uma justificativa para a personalização dos serviços ("Porque só é perfeito para nós quando é perfeito para você"), tendo no advérbio "só" uma reafirmação dessa justificativa. O advérbio funciona 
como operador argumentativo, estreitando e direcionando a interpretação, como se o que foi dito só pudesse ser dito daquela maneira.

Este anúncio do Itaú Personnalité ressalta o sujeito como único, exclusivo, importante, por isso os serviços serem voltados a cada um, individualmente, atendendo, assim, às necessidades de cada cliente em especial. Segundo o site desta seção do banco Itaú ${ }^{8}$ “o Itaú Personnalité é um segmento do Banco Itaú especializado em atendimento diferenciado dirigido à pessoas físicas que necessitam de orientação financeira e atendimento personalizado na administração dos seus recursos". No mesmo site, a instituição bancária esclarece que os clientes do Itaú Personnalité são "pessoas que acompanham os principais acontecimentos do mercado financeiro e por isso demandam orientação especializada e segura". Conforme o que foi exposto, percebemos que o grupo de interlocutores desta propaganda, na verdade, é bastante restrito, uma vez que são apenas pessoas físicas (o que exclui as empresas) e "pessoas que acompanham os principais acontecimentos do mercado financeiro". Se nos voltarmos para as condições de produção do discurso, notaremos que as pessoas, conforme descritas, são aquelas com poder aquisitivo elevado, já que são elas que têm interesse em acompanhar o mercado financeiro para melhor administrar seus bens e recursos. Então, embora pareça que a propaganda se destine a todos, ela foi elaborada para um público específico, indivíduos com condições financeiras para fazer parte do seleto grupo de pessoas que desfrutam do atendimento personalizado do Itaú Personnalité.

A propaganda anterior do Itaú tem como slogan "Feito para você", enquanto esta apresenta "Perfeito para você", havendo um deslizamento de sentido de "feito" para "perfeito". Houve um jogo de palavras, pela semelhança das mesmas, uma vez que "feito" está na composição da palavra "perfeito". Com este deslizamento busca-se individualizar ainda mais o leitor, dando este efeito de exclusividade e importância de cada um, em

\footnotetext{
${ }^{8}$ www. itaupersonnalite.com.br.
} 
conformidade com os serviços e produtos personalizados deste segmento do banco Itaú. Mas, como já mencionamos, o grupo de interlocutores deste anúncio é bem específico.

Quanto ao não-verbal, o anúncio nos apresenta um homem bem vestido, de meia-idade, que traz à memória um executivo. Ele está sentado e voltado para o leitor da revista, sorrindo levemente. Ao fundo, estão ilustrações que trazem à memória a arquitetura moderna. Os enunciados citados e o logotipo do Itaú estão inscritos numa superfície que lembra um pequeno caderno de anotações. Por extensão, podemos dizer que o homem que estampa o anúncio é um arquiteto e que o projeto ilustrado é "feito para você", ou seja, para o interlocutor da propaganda. Verbal e não-verbal são, assim, individualizantes.

No que se refere à enunciação, há um enunciador coletivo "nós" que fala da posição do banco Itaú. O enunciador "nós" dirige-se a um leitor individualizado, designado por "você".

Ressaltamos, ainda, nesta propaganda, o uso do francês no logotipo (Itaú Personnalité), que funciona, no plano imaginário, como conferindo sofisticação e refinamento ao serviço prestado pelo banco. Esse funcionamento imaginário se pauta na memória, já que a língua francesa remete à elite, à erudição, à cultura e ao refinamento. O emprego do francês em detrimento do inglês, por exemplo - se deve, em nosso entender, a uma busca de diferenciação em relação a outras instituições bancárias e aos serviços por elas oferecidos, já que em algumas propagandas de bancos usam-se palavras do inglês na composição do anúncio (como em Santander Reward).

Quanto ao processo de individualização neste anúncio, ele deixa pistas de seu funcionamento no verbal e no não-verbal, como já vimos explicando. No verbal, há o uso da pronominalização "você" e "seu”, além de "personnalité", ou personalizado. No não-verbal, observa-se o olhar do homem que se dirige ao leitor da propaganda, o crachá e a letra do que 
está escrito nele, uma letra também personalizada (letra cursiva ou "letra de mão"), como se alguém tivesse escrito cuidadosamente à mão, numa prática artesanal.

A terceira propaganda, do Itaucard, cartão de crédito do banco Itaú, apresenta como garoto-propaganda o ator Dan Stulbach. Este atua na televisão, no teatro e no cinema brasileiros, sendo um ator famoso e de talento reconhecido no meio artístico. Neste anúncio ele aparece fazendo um movimento característico da dança conhecida como Hip Hop, ao lado de um aparelho de som, diante do qual estão vários cd's. Não podemos afirmar se foi mesmo o ator que fez o movimento de dança ou se estamos diante de uma montagem de computação. Quando questionado sobre isso, em várias entrevistas na imprensa falada e escrita, o ator não desmente nem uma nem outra versão dos fatos.

O enunciado em destaque no anúncio "Você tem a vontade. Nós temos o cartão" se relaciona com a imagem, na medida em que ao lado do ator Dan Stulbach está um comprovante de pagamento de venda a crédito no Itaucard em nome do ator, e que mostra a compra de cd's de Hip Hop. Há ainda no anúncio dois cartões - um Itaucard Visa e outro da Mastercard - em nome de Dan Stulbach. De acordo com a composição verbal e imagética do anúncio, podemos afirmar que o uso do cartão de crédito foi o que possibilitou ao ator fazer o que era a sua vontade, no caso, comprar os cd's para dançar Hip Hop. Indo além, podemos afirmar que foi o cartão que proporcionou ao ator fazer o próprio movimento, se pensarmos na questão de superação que o Itaucard incita no sujeito, que, de posse do cartão, pode "ter mais".

Além de mostrar o funcionamento do imaginário e as possibilidades simbólicas da linguagem, este anúncio do Itaucard trabalha intensamente a forma-sujeito contemporânea que, como já dissemos, caracteriza-se por um sujeito com livre circulação social, dono suas vontades e responsável por elas. A questão principal que emerge, então, é o sujeito dono de sua vontade. O Itaucard seria um auxílio, sendo que seu uso ajudaria a concretizar a vontade 
do sujeito. Além disso, o banco aponta facilidades no uso do cartão como "aumento automático de limite" e "parcelamento no ato da compra ou parcelamento da fatura em até 12 vezes fixas". Quanto mais fáceis a compra e o pagamento, mais incentivado fica o consumo. E o consumo, por seu turno, seria a concretização do desejo do sujeito.

No que tange à enunciação, observamos novamente um enunciador coletivo "nós”, que fala da posição do banco Itaú, e que se dirige a um leito individualizado tratado por "você". Do ponto de vista discursivo, o pronome "nós" coletiviza e marca a posição da empresa, enquanto instituição organizada que trabalha para um "você".

Novamente, no slogan do Itaú - como aconteceu na propaganda do segmento Personnalité - ocorreu um jogo de palavras, desta vez, para ficar mais condizente com o produto anunciado - o cartão. Segundo a propaganda, o Itaucard é "Feito para quem tem conta no Itaú. Feito para quem não tem. Itaucard. Feito para você ter mais”. Com esta colocação, o anúncio amplia seus interlocutores, já que estes não se limitam aos clientes do banco, mas sim, a todos os interessados em possuir o cartão e que desejariam "ter mais". A falta de especificação (ter mais o quê?) deixa em aberto as possibilidades de interpretação por parte do leitor. Mas, relacionando esta propaganda às outras duas do mesmo banco nesta série, poderemos dizer que está implícita a palavra "benefícios", ficando o slogan do cartão como "Feito para você ter mais" (benefícios).

A propaganda do Banco Santander tem como garotos-propaganda os atores Fernanda Torres e Selton Melo. Ambos atuam na televisão, no cinema e no teatro brasileiros e, assim como Dan Stulbach, são famosos e reconhecidos na área em que atuam. Os dois protagonizaram uma série de diferentes propagandas do Santander em comerciais de televisão e na publicidade impressa. Aos dois atores atribuíram o enunciado "Chega de juntar pontos para nada”. Seria uma crítica a outros bancos? 
Em contraposição a "chega de juntar pontos para nada" está a sequência “Chegou Santander Reward”. Esta contraposição se organiza em torno da palavra "créditos", que, por sua vez, em oposição a "nada", "viram créditos em dinheiro" para o cliente do banco. Observemos os enunciados (todos os grifos são meus):

"Agora suas compras viram créditos em dinheiro para você".

"2\% do valor de suas compras vira créditos".

Créditos que crescem a cada ano".

Créditos que nunca expiram".

Créditos para usar como, quando e onde quiser".

Vemos, pelas sequências acima, que ao fazer uso do cartão Reward, uma porcentagem do valor das compras se transforma em créditos em dinheiro para uso do cliente “como, quando e onde" ele quiser. Vemos aí novamente a interpelação que resulta na formasujeito, que se caracteriza pelo sujeito "livre", com vontade própria.

Neste anúncio, relacionamos "compras" a "fidelidade" e "Reward" a "recompensa", com base nas sequências:

“Agora suas compras viram viram créditos em dinheiro para você". (grifo meu) "Santander Reward. Recompensa seu uso. Reconhece sua fidelidade". (grifos meus)

Relacionamos "compra" e "fidelidade", porque quanto mais o cliente compra, ou seja, quanto mais utiliza o cartão, o banco vê nele um cliente "fiel" ao banco "reconhecendo sua fidelidade". A imagem da fidelidade, que evoca o discurso amoroso, da amizade e religioso se relaciona com as relações sociais ao longo da história. "Reward" e “recompensa”, por sua vez estão numa relação de paráfrase, já que esta é a tradução daquela. 
Em "peça já o seu” (grifo meu), a palavra grifada, um advérbio de tempo, funciona como um operador argumentativo que, juntamente com o imperativo "peça" interpelam a uma ação imediata por parte do leitor do anúncio. No mesmo contexto, "chegou" e "agora" apontam para o momento da interlocução e, assim, para a atualidade.

No que tange à utilização de palavras ou expressões polissêmicas, estratégia amplamente usada pela publicidade, que trabalha com a língua em movimento, destacamos a palavra "valor" nos enunciados:

"O Santander tem idéias que trazem mais valor para sua vida". (grifo meu)

"Santander, o valor das idéias". (slogan do Banco, grifo meu)

No funcionamento discursivo do anúncio, "valor" tem sentido de valor financeiro, de dinheiro, e também sentido de importância (“a importância das idéias”).

Destacamos, ainda, marcas do discurso da internacionalização e da globalização, respectivamente, com as palavras grifadas no enunciado a seguir: "O banco internacional com mais agências no mundo". (grifos meus)

O quarto e último anúncio da série é do Banco do Brasil, cujo slogan é "Todo seu". O pronome "todo" indica totalidade, e no anúncio funciona marcando uma imagem de completude do banco. O uso de "seu" em detrimento de teu remete ao discurso cotidiano, no qual aquela pronominalização é mais usada do que esta.

Na propaganda do Banco do Brasil verbal e não-verbal estão funcionando em conjunto. A imagem mostra a foto de Ricardo e Emanuel num gesto de torcida. Eles são uma famosa dupla de esportistas do vôlei de praia brasileiro, patrocinada pelo banco. Para melhor entendermos as condições de produção, procuramos no site do banco ${ }^{9}$ como se daria sua relação com o discurso esportivo. Lá, encontramos que, desde 1991, o Banco do Brasil

\footnotetext{
${ }^{9}$ www.bb.com.br.
} 
patrocina tanto eventos esportivos quanto atletas brasileiros (vôlei de praia e de quadra, iatismo, tênis, futsal, corrida de rua) como uma forma de "Marketing Institucional".

O anúncio se refere à "Promoção Ourocard BB 200 anos", na qual os clientes do banco, usando o cartão, concorrem a diversos prêmios em dinheiro. O enunciado em destaque na página "Sabe qual a melhor maneira de retribuir a sua torcida? Torcer por você" pode ser atribuído aos atletas, que estariam retribuindo a torcida feita pelos brasileiros, em especial os clientes do Banco do Brasil. As palavras "torcer", "torcida", "ganhadores" e "ganhar" fazem parte do discurso esportivo, e se relaciona com a imagem dos atletas. A foto e o texto conjuntamente interpelam o leitor a participar da promoção.

No enunciado "Banco do Brasil. 200 anos fazendo o futuro", observamos a tentativa de mostrar credibilidade ao possível cliente, dado o tempo em que o banco está estabelecido. Ademais, vemos funcionar aí um passado que aponta para o futuro, fazendo-o (re) significar.

As pistas do processo de individualização do sujeito estão na pronominalização, com o uso do pronome de tratamento "você", e pelo uso do modo imperativo do verbo ("use"), que interpelam a uma ação individual do leitor da propaganda: participar da promoção promovida pelo banco.

\section{Considerações finais}

Para terminar esta dissertação sem no entanto concluí-la, mostraremos as regularidades que atravessam todas as séries que tomamos para análise, tecendo ainda mais alguns apontamentos sobre as marcas do processo de individualização com as quais nos deparamos em nosso percurso analítico. Estas regularidades fazem parte do processo discursivo, que foi definido por Michel Pêcheux (1993, p. 181) 
como o resultado da relação regulada de objetos discursivos correspondentes a superfícies lingüísticas que derivam, elas mesmas, de condições de produção estáveis e homogêneas. Este acesso ao processo discursivo é obtido por uma de-sintagmatização que incide na zona de ilusãoesquecimento número um.

Como já tivemos ocasião de dizer, o discurso publicitário trabalha a produção de evidências e com o imaginário. Orlandi (2001, p. 71) afirma que

o discurso, por princípio não se fecha. É um processo em curso. Ele não é um conjunto de textos, mas uma prática. É nesse sentido que consideramos o discurso no conjunto das práticas que constituem a sociedade na história, com a diferença de que a prática discursiva se especifica por ser uma prática simbólica.

Nesse contexto, pensamos o texto publicitário como material simbólico, no qual pode-se identificar a imagem da sociedade e do sujeito contemporâneos ali materializados. Os textos da propaganda, como o concebemos neste estudo, ultrapassam um funcionamento meramente informativo. Além de apresentar aos possíveis consumidores a existência de um produto ou serviço, a propaganda apresenta uma "orientação ideológica" (ORLANDI, 2009b), o que implica, a nosso ver, numa "gestão da subjetividade" (Id., Ibid). esta diz respeito ao equívoco do sujeito de pensar-selcomo origem de si. É o teatro da consciência de que nos fala Pêcheux.

Relacionando o discurso da propaganda, a constituição do sujeito contemporâneo e nossa formação social, afirmamos que a propaganda é a materialização do sujeito de consumo. Digo isso porque entendo que a publicidade mantém estreita relação com o ato de consumir enquanto "gesto simbólico" (CARROZZA, 2010), como já mencionado. O deslocamento de ato para gesto me permite pensar nas formas de pertencimento (pertencimento ao grupo que o Mercado constitui, apagando o social) que adquirir determinados produtos e não outros propicia ao sujeito. 
A constituição do sujeito na contemporaneidade também se dá em termos do que ele consome. Atenta às transformações sociais e dos sujeitos, a publicidade sempre almeja uma identificação entre o que está sendo oferecido para compra e o possível consumidor. Esta busca permanente pela identificação é que possibilita aos profissionais de propaganda mostrarem na materialidade do anúncio a imagem que têm do leitor, "já individualizado e identificado com o consumidor esperado" (Id., Ibid., p. 18).

Traçando um paralelo entre a propaganda e a psicologia, Orlandi (2009b), considera que o papel da propaganda é "saber comunicar, saber tocar as pessoas, se ajustar às pessoas para ajustá-las, para melhor mirar o alvo de suas cabeças". Discorrendo sobre os sujeitos e os discursos no contemporâneo, Mariani (2009, p. 49-50), baseando-se nas considerações do filósofo Dufour, que

[...] hoje, na economia neoliberal, assistimos a condenação desse sujeito duplamente determinado - pela lei e pela culpa - e vemos o nascimento de um sujeito a-crítico, 'disponível para todas as conexões, um sujeito incerto, indefinidamente aberto aos fluxos de mercado e fluxos comunicacionais, em carência permanente de mercadorias para consumir'.

Outra questão importante que permeia o funcionamento do discurso estudado é a relação existente entre o sonho, o desejo e a ideologia, que percebemos nos enunciados:

"Sonhe com o mundo." (CVC)

"The power of dreams." (“O poder dos sonhos”, tradução minha, propaganda da Honda)

“A Wizard realiza seus sonhos.” (propaganda da Wizard)

Entendemos que o desejo é o objeto da propaganda. A ideologia só funciona pelo desejo e este segue o rastro da ideologia. A propaganda alimenta o gesto contínuo de produção da falta, o que vai ao encontro da lacuna constitutiva do sujeito, enquanto desejante e que tem no desejo e no sonho elementos fundamentais para a subjetividade. 
Nos anúncios que analisamos, o sonho fica a cargo do interlocutor ("você”) e àempresa ("nós", "a gente”) cabe a concretização desse sonho enquanto materialização do desejo. No caso da propaganda, isso se dá pela aquisição do produto ou serviço anunciado. O que se percebe, dessa forma, é que para a publicidade o desejo é sempre realizável, mas para a psicanálise, o desejo é da ordem do inatingível, nunca se realiza plenamente. Com base na teoria psicanalítica, Hansen (2009, p. 177) diz que esta

concebe o desejo como imaginário em suas vias de realização, na medida em que ele é regido pela trama se sua fantasia. Aí está, portanto, também, a fantasia em sua função de promover a satisfação, articulada ao desejo inconsciente. A ilusão com a qual o sujeito é vestido, busca articulá-lo com o desejo enigmático, impossível, que, se pudesse ser apreendido, o deixaria sem faltas. São esses impasses do sujeito que o fazem permanecer, constantemente, na condição de sujeito desejante.

Notamos em nosso corpus que o ambiente urbano é pouco contemplado nos anúncios - o que constitui uma regularidade - nos quais aparecem espaços não-urbanizados ou mesmo criados em estúdio. As propagandas em que se faz menção ao urbano são a da CVC (prop 01), na qual Nova York aparece ao fundo; a da DELL (prop. 20) em que o rapaz está numa lanchonete, o que remete ao ambiente citadino; a do Itaú Personnalité (prop. 22) na qual é mostrado um projeto de arquitetura moderna. Acreditamos que a pouca referência ao urbano se constitui num gesto de interpretação dos publicitários. Estes possivelmente foram atravessados pelo imaginário social contemporâneo que vê a cidade como perigosa, violenta, estressante, caótica. Tudo isso gera o chamado "medo urbano" (Dalben, 2009), da ordem do imaginário. Como nossos textos de análise são oriundos de revistas, eles têm como interlocutores, majoritariamente, indivíduos que vivem nas cidades, os publicitários evitaram estampar o espaço citadino, imaginando, com esse gesto, promover uma maior identificação com o leitor, também exposto ao mesmo imaginário social. 
Uma outra questão importante que gostaria de apontar é a de que a formasujeito atual sustenta os dizeres dos anúncios. Resultado de um processo de determinação histórica, a forma-sujeito com sua materialidade, difere de uma conjuntura histórica para outra. Atualmente, Orlandi (2008, p. 104) assim a caracteriza:

O sujeito moderno - capitalista - é ao mesmo tempo livre e submisso, determinado (pela exterioridade) e determinador (do que diz): essa é a condição de sua responsabilidade (sujeito jurídico, sujeito a direitos e deveres) e de sua coerência (não-contradição) que lhe garantem, em conjunto, sua impressão de unidade e controle de (por) sua vontade. Não só dos outros, mas até de si mesmo. Bastando ter poder...

São as características da forma-sujeito, que Orlandi elenca, que sustentam os seguintes enunciados: (todos os grifos são meus)

“Agora quem escreve seu destino é você". (Honda, prop. 08)

“[...] para almoçar ou jantar onde quiser". (Visa, prop. 10)

“[...]para usar no restaurante à sua escolha”. (idem)

“Compre o seu DELL do seu jeito". (DELL, prop. 20)

“Compre a qualquer dia e hora". (idem)

“Tem o benefício de contar com milhares de agências e caixas eletrônicos pelo Brasil e, se preferir, o melhor banco pela internet”. (Itaú, prop. 20)

"Você tem a vontade". (Itaucard, prop. 23)

“Créditos para usar como, quando e onde quiser". (Santander, prop. 24)

No que concerne às pessoas que representam as marcas ou os produtos, os garotos-propaganda, apuramos que as empresas ora optam por pessoas famosas (atores, atletas, etc), ora escolhem indivíduos desconhecidos do grande público. Outra escolha possível é a de não se colocar pessoa alguma, como o foco somente para o que está sendo anunciado. Quando se escolhe uma pessoa famosa para representar a marca, o produto ou o serviço, certamente há uma identificação entre o garoto(a)- propaganda e a proposta da 
empresa, e também espera-se uma identificação do leitor com o famoso. A opção por colocar atletas nos anúncios se deve tanto ao fato de estes serem patrocinados pela empresa (caso da Wizard e do Banco do Brasil), quanto neste patrocínio consistir em um marketing institucional, que dá mais visibilidade à empresa por meio do esporte.

Em nossos textos de análise notamos marcas verbais e não-verbais que nos indicam o atravessamento do discurso publicitário por outros discursos, que circulam socialmente em larga escala, podendo, assim, serem considerados discursos dominantes. Vejamos.

O discurso ecológico se mostra em “ar condicionado ecológico”(Kia, prop. 05) e nas paisagens naturais (propagandas 07, 08 e 13). Afirmamos que a preocupação com as questões ambientais por parte das empresas demonstraria ao público um engajamento político. Para os clientes, consumir produtos de empresas comprometidas com causas ambientais é praticar um consumo consciente.

O discurso sobre a beleza se faz dizer pela "inflação da imagem” (ORLANDI, 2009 a, p. 14). A ele se ligam as chamadas ditadura da beleza e da magreza, que impõem à mulher um jeito de mostrar-se ao mundo, que, por seu turno, tem a ver com a aceitação social do indivíduo. Encontramos pistas do funcionamento desse discurso na propaganda da Batavo (prop. 13), conforme expusemos na análise da série de que este anúncio faz parte.

Ressaltamos ainda um discurso sobre a mulher, que apresenta questões sobre o imaginário e os estereótipos, e nos aponta uma mulher "multifacetada", que é, ao mesmo tempo, independente, necessita de "segurança e proteção", é mãe, etc. Esse discurso está presente nas propagandas da SulAmérica (prop. 11 e 12) e da Johnson's (prop. 14).

Encontramos, ainda, marcas do discurso da globalização ou mundialização. Esta se refere a relação entre os países e a um processo de homogeinização das relações comerciais, situadas sob a égide da formação ideológica capitalista. Para Orlandi (2009 a, p. 
15) “a mundialização é mais falada que praticada. Mas nem por isso deixa de ter seus efeitos. Como sabemos, o imaginário tem fortes consequiências sobre o real". As marcas do discurso da globalização, no não-verbal, são fotos de outros países (propagandas 1,2 e 3 da CVC), e no verbal: (os grifos são meus)

"Sonhe com o mundo." (CVC)

“Topo do mundo.” (Wizard, prop. 09)

“Paris, New York, Tokio.” (Avon, prop. 15)

“Hoje, meu concorrente é o mundo inteiro". (Intel, prop. 18)

“[...] estou conectado em qualquer parte do planeta". (Idem)

“O banco internacional com mais agências no mundo.” (Santander, prop. 24)

Falamos até agora, nestas considerações finais, sobre algumas regularidades no discurso publicitário que observamos em nosso corpus. Passaremos, neste momento, a discorrer sobre as marcas do processo de individualização do sujeito, tal qual teorizado no primeiro capítulo desta dissertação.

Quanto à pronominalização, apontamos o emprego de "seu”, "sua”, “seus", "suas", "meu", que individualizam por também marcarem um certo tipo de abordagem junto ao leitor, abordagem esta que produz o efeito de um único leitor. Acrescentamos que como os anúncios designam por "você" seu interlocutor, se poderia esperar que se usasse o possessivo "teu". No entanto, o pronome "seu" funciona nas propagandas como um pronome de segunda pessoa, referindo-se ao "você". A escolha de "seu" em detrimento de "teu", acreditamos, se deve ao fato de aquele estar inserido no discurso cotidiano, desfrutando de maior circulação social.

Uma outra pista do processo estudado é a adjetivação, como em:

"Exclusivos" (Honda, prop. 08)

"Exclusiva" (SulAmérica, prop. 11 e 12) 
"Personalizada" (Itautec, prop. 17)

"Personnalité” (Itaú, prop. 22)

Estes adjetivos também fazem referência ao "você", identificado com o leitor do anúncio e produzido em sua individualidade.

No que se refere ao não-verbal, observamos a regularidade de que nas fotos dos anúncios, as pessoas estão normalmente sozinhas, individualizadas. Isso se relaciona com o que dissemos anteriormente sobre vivermos numa sociedade individualista.

Quanto à relação entre o verbal e o não-verbal na materialidade do discurso, afirmamos que eles estão imbricados. Com base nos arranjos verbais e imagéticos dos anúncios, podemos dizer que eles funcionam conjuntamente na produção de sentidos do texto propagandístico.

Ao longo da análise das séries afirmei que o modo imperativo do verbo constitui uma marca lingüística da individualização. Para mim, o imperativo se mostrou como um fazer agir que produz uma "escuta individual" (CARROZZA, 2010). O que chamo de fazer agir, Orlandi (2009b) caracteriza como performatividade, segundo a qual dizer equivale a fazer, com uma identificação do sujeito com sua consciência". Para a autora (Idem), “ a propaganda traz novos performativos que interpelam os sujeitos a partir de seu próprio narcizismo".

Finalmente, no que tange à enunciação, percebemos dois processos: a individualização e a coletivização. Esta última marca a posição da empresa como grupo organizado, identificada nos anúncios por "a gente" ou "nós". O que há, portanto é uma sinonímia entre o nome da empresa e essa nomeação (“a gente” ou "nós”). A individualização, por sua vez, se dá com o interlocutor do anúncio, individualizado e sempre nomeado por "você". Mas quem é afinal esse VOCÊ? 
Entendo que embora os textos propagandísticos se dirijam a todos e a cada um simultaneamente, este cada um, não corresponde a um "você" uno, mas ambíguo. Tal pronome de tratamento explicita como interlocutor do anúncio tanto o indivíduo individualizado quanto homogeneizado. Falo em homogeneidade da nomeação porque nesse "você" há um apagamento do político, do econômico e do lugar social do sujeito. As diferenças são, portanto, silenciadas.

Nosso trabalho, finalmente, é um recorte feito a partir de uma questão colocada face ao corpus: como se dá o processo de individualização do sujeito no discurso publicitário? Este discurso, certamente, nos ajudou a compreender um pouco desse processo tão importante e atual, mas ainda ficam muitas questões a serem respondidas. Esperamos que nosso estudo contribua para as pesquisas da área, já que entendemos que as diversas pesquisas em Análise de Discurso fazem emergir novas questões e novos conceitos, e estes concorrem para o constante aprimoramento da teoria e do método que embasa todas essas pesquisas. 


\section{Referências bibliográficas}

ALTHUSSER, L. Ideologia e aparelhos ideológicos do estado. Lisboa: Editorial Presença, 1980.

BAUMAN, Z. O mal-estar da pós-modernidade. Rio de Janeiro: Jorge Zahar, 1998.

BIRMAN, J. O sujeito desejante na contemporaneidade. In: SEMINÁRIO DE ESTUDOS EM ANÁLISE DO DISCURSO, 2, 2005, Porto Alegre - RS: Universidade Federal do Rio Grande do Sul, 2005, p. 1-18.

CARroZZA, N. G.V. Publicidade: o consumo e sua língua. Campinas - SP, 2010. 148f. Tese (Doutorado em Linguística) - Instituto de Estudos da Linguagem, Universidade Estadual de Campinas, Campinas - SP.

DALBEN, A. Vida malsã versus natureza como refúgio: praia e montanha no discurso médico da formação de corpos infantis vigorosos. Campinas-SP: UNICAMP, 2009. Disponível em: http://www. labeurb. unicamp.br/portal/pages/videos/verVideo.lab ? id=94. Acesso em : 10 jun. 2010. (vídeo)

DAVAlLON, J. A imagem, uma arte de memória. In: Papel da memória. Trad. José Horta Nunes. Campinas - SP: Pontes, 2007.

FERREIRA, L. C. Práticas de leitura contemporâneas: representações discursivas do leitor inscritas na Revista Veja. Araraquara-SP: 2006, 337f. Tese (Doutorado em Lingüística e Língua Portuguesa) - Faculdade de Ciências e Letras, Universidade Estadual Paulista, Araraquara - SP.

FOUCAULT, M. A arqueologia do saber. Trad. Luiz Felipe B. Neves. Rio de Janeiro: Forense Universitária, 2000.

GUIMARÃES, E. Semântica do acontecimento: um estudo enunciativo da designação. Campinas, SP: Pontes, 2005.

HANSEN, F. Heterogeneidade discursiva: o atravessamento do outro no processo criativo do discurso publicitário. Porto Alegre - RS, 2009. 223f. Tese (Doutorado em Teorias do Texto e do Discurso ) - Universidade Federal do Rio Grande do Sul, Porto Alegre - RS.

HAROCHE, C. Fazer dizer, querer dizer. Trad. Eni P. Orlandi et al. São Paulo, Hucitec, 1992.

HARTMANN, F. Ideologia e Desejo. In: FERREIRA, M. C.L.; INDURSKY, F. Michel Pêcheux e Análise do Discurso: uma relação de nunca acabar. São Carlos: Claraluz, 2007. 
LEWKOWICS, I; CANTARELLI, M. e Grupo Doze. Do fragmento à situação: anotações sobre a subjetividade contemporânea. Trad. Maria Onice Payer e Romualdo Dias, 2006.

MARIANI, B. Sujeitos e discursos contemporâneos. In: FERREIRA, M.C.L.; INDURSKY, F.; MITTMANN ,S. (Org.) O discurso na contemporaneidade: materialidades e fronteiras. São Carlos: Claraluz, 2009.

Silêncio e metáfora, algo para se pensar. Revista Trama. v.3, n.5, p. 55-71, 2007.

NUNES, J.H. Definição lexicográfica e discurso. Língua e Instrumentos Linguísticos, 11, p. 09-29, 2001.

Aspectos da forma histórica do leitor brasileiro na atualidade. In: ORLANDI, E. P. (Org.). A leitura e os leitores. Campinas-SP: Pontes, 1998.

Formação do leitor brasileiro. Imaginário da leitura no Brasil colonial. Campinas SP: Editora da UNICAMP, 1994.

ORLANDI, E. P. Historicidade, indivíduo e sociedade: o sujeito na contemporaneidade. In: FERREIRA, M.C.L.; INDURSKY, F.; MITTMANN ,S. (Org.) O discurso na contemporaneidade: materialidades e fronteiras. São Carlos: Claraluz, 2009.

Brasil um país de todos: o discurso da propaganda política. Campinas-SP: Sala do Colegiado do Instituto de Estudos da Linguagem da UNICAMP, 2009b. Disponível em :<http: // www. Labeurb. unicamp.br/portal/pages/vídeos/verVideo.lab?id=83>. Acesso em: 10 jun. 2010. (vídeo)

2008.

Discurso e Texto: formulação e circulação dos sentidos. Campinas - SP: Pontes,

O sujeito discursivo contemporâneo: um exemplo. In: FERREIRA, M. C.; INDURSKY, F. (Org.) Análise do discurso no Brasil: mapeando conceitos, confrontando limites. São Carlos, SP: Claraluz, 2007, p. 11-20.

À flor da pele: indivíduo e sociedade. In: MARIANI, B. (Org.) A escrita e os escritos: reflexões em Análise do Discurso e Psicanálise. São Carlos: Claraluz, 2006a.

Análise de Discurso. In: ORLANDI, E. P.; LAGAZZI-RODRIGUES, S. (Org.)

Discurso e Textualidade. Campinas - SP, Pontes, 2006b. (Introdução às Ciências da Linguagem).

Conversa com Eni Orlandi. Teias, Rio de Janeiro, ano 07, n. 13-14, 2006c 
Análise de discurso: princípios e procedimentos. Campinas, SP: Pontes, 2001.

o inteligível, o interpretável e o compreensível. In: __. Discurso e leitura. Campinas-SP: Cortez, 1996a. $1996 \mathrm{~b}$.

. A linguagem e seu funcionamento: as formas do discurso. Campinas - SP: Pontes, Efeitos do verbal sobre o não-verbal. Rua, 1, 1995, p. 35-47.

PAYER, M. O. Linguagem e sociedade contemporânea - sujeito, mídia, mercado. Rua, 11, 2005, p. 9-25.

PÊCHEUX, M.. Semântica e discurso: uma crítica à afirmação do óbvio. Campinas, SP: Editora da UNICAMP, 1995.

. Análise Automática do Discurso (AAD-69). In: GADET,F.; HAK, T. (Org.) Por uma análise automatic do discurso: uma introdução à obra de Michel Pêcheux. Campinas - SP: Editora da UNICAMP, 1993.

ROLNIK, S. Subjetividade e História. Rua, 01, 1995, p. 49-61. 


\section{ANEXOS}




\section{Viagens Internacionais}

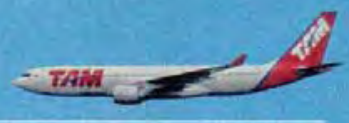

Pacotes e circuitos especiais para os mais famosos destinos turisticos do mundo, como América do Sul, Europa, Africa, Asia, Caribe e Estados Unidos. Induidos nos roteiros: passagem aérea, hospedagem, seguro viagem e assistência especializada CVC.

Cancún 7 noitess particide $10 \times \operatorname{RS} 269$

Voando Aeroméxico. Saidas em setembro e outubro. Hospedagem no Hotel Oasis Palm Beach, de frente para o mar, com café da manhả. Passeio aos principais pontos turisticos da ilha. A vista 2.690, Base US\$ 1.518, Preço p/ dasse turistica.

Lagos Andinos 12 noites A partir de.

$8 \times R 5566$

Voando Aerolinease L LAN. Saldas 10, 4, 7 e 10//setembro. 3 noites em Santiago, lem Puert Varas, 1 noite em Peulla, 3 noites em Bariloche e 3 en Buenos Aires. Inclui travessia dos lagosem catamara.A Avista R5 4.528, Base US52.558,

Bariloche 7 noites a partirde

10x RS 244

Fretamento exclusivo TAM. Saidas diárias. Com cafe e jantar no Hotel Colonial Passeios pelos Circuito Chicco, Cerro Campanário, ponto panoràmico e Cerro Catedral. Ingresso para o cassino de Bariloche, visita à fábrica de chocolate, 6 dias de roupa especial para neve. A vista RS 2.440 , Base USS 1.378 , Preço p/ saida $9 / 2$ gosto.

Buenos Aires 4 e 5 dias A partirde.

10xRS 111

Voando TAM. Saidas de 18/agosto a 1\%/dezembro. Hospedagem no Hotei Waldorf. Passeio aos principais pontos turisticos da cidade. A vista RS 1.110 , Base US5 628 Preşo para 4 dias.

Nova York 3 noites A partiride

$10 \times$ Rs 243

Voando TAM. Saidas diarias. Hospedagem no Hotel Radisson Martinique, no coraço de Nova York e próximo as principais lojas da cidade. A vista RS 2,421, Base USS 1,368 Preso p/saidas de 25/julho a 29/agosto.

Escandinávia 13 noites A partirde.

$5 \times \mathrm{RS} 2.171$

Voando Lufthansa. Saidas 22/agosto e 12/setembro. 2 noites em Copenhague, 1 noite em cruzeiro de Copenhague a Oslo, 2 em Osio, 1 em Lofthus, 1 em Bergen, 1 em Balestrando Tem Loen, 1 em Lillehamere 3 em Estocolmo. Visitas a aos fiordes noruegueses, Glacial de Briksdal em carro elétrico. Indui S jantares. Avista RS 10.857, Base 63.948 , Consulte opgảo de 20 noites com extensio a Russia.

Leste Europeu 10 noites A partiride.

5xRS 1.423

Com guia acompanhando desde o Brasil. Voando Lufthansa. Saida $13 / 2$ gosto. 2 noites em Viena, 3 em Budapeste, 3 em Praga e 2 em Berlim. A vista RS 7.117, Base 62.588 Consulte opgra de 12 noites com extenşäo a Rússia.

Paris 6 noites A partic de

$5 \times$ RS 642

Voando TAM. Saldas diarrias. Hotel le Quartier Republique, no corardo de Paris Exclusividade CVC: guias falando português em Paris. A vista RS 3.210 , Base 61.168 Preço $p /$ saidas em agostio e setembro.

\section{Os melhores destinos do mundo. Porque você não trabalha 8 horas por dia para passar férias num lugar qualquer.} Para todo mundo, existe uma CVC.
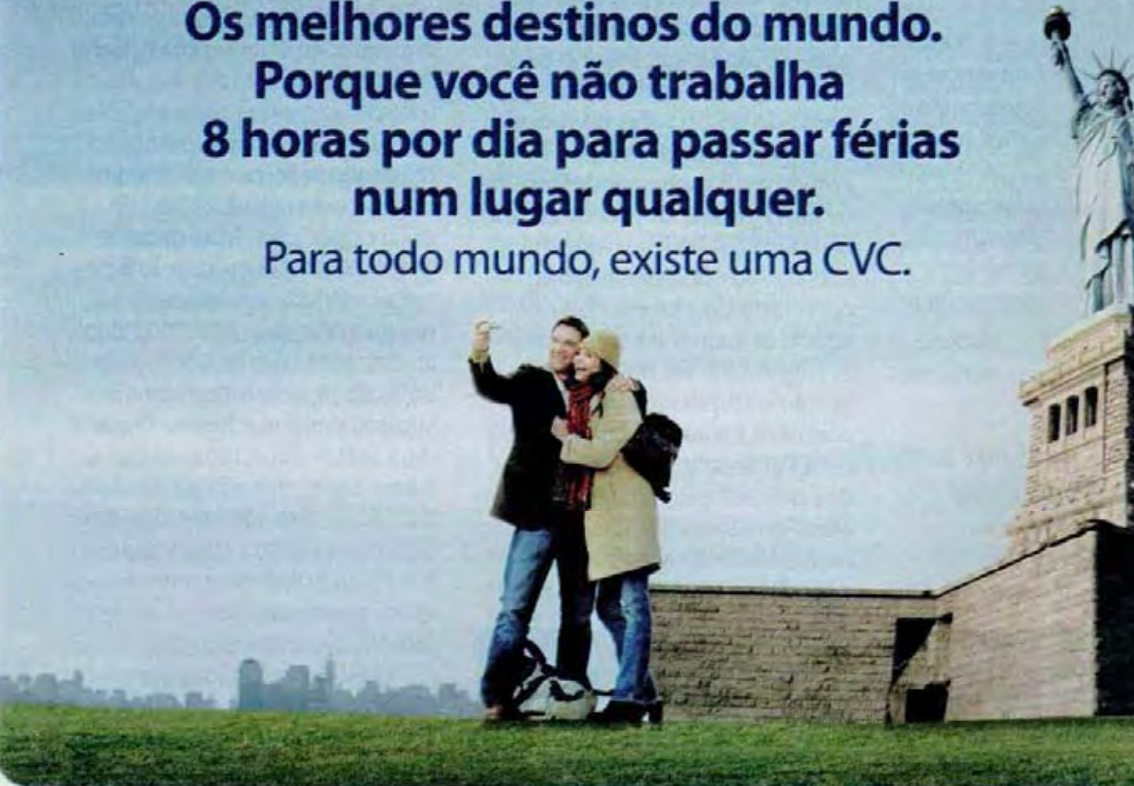

Visite uma loja CVC nos melhores shoppings do Brasil ou, se preferit, ligue: SSo Paulo 11 2146-7011/2103-1222 - Santo Andre 11 2191-8700 - Säo Bemardo 11 2191-3500 Sáo Getano 11 3636-3450 - Masa 1145194700 - Diadema 11 4043-2928 - Osasco 11 3699-9909 - Campinas $192117-3500$ - Mogi das Cruzes 1147992166 - Surzano 112148 - 4600

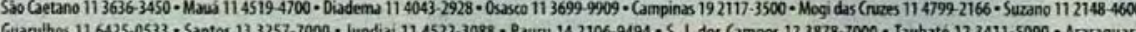
163331 - G

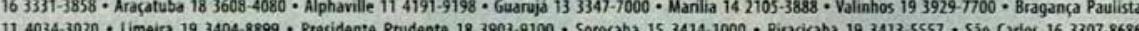
11 4034-3020 - Umeira $193404-8899$ - Mresidente Prudente $183903-9100$ - Sorocaba is $3414-1000$ - Piracicaba $193413-5557$ - Sajo Carlos 16 3307-8686 Ribeirao Preto $162101-0018$ - Hortinga $163341-8210$ - Garden Catanduva $173525-2097$ - Rio Preto 17 2137-5910 - Porto Aiegre $512121-1621$ - Florianopolis

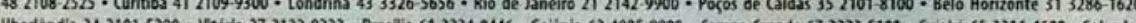
Uberlandia $342101-5200$ - Vhona $272122-8222$ - Brasilia 6132340446 - Goiania 62 4005-8900 - Campo Grande $673323-5100$ - Culaba $653316-4600$ - Salvador 71 2103-5666 - Aracaju 79 2107-8999 - Maceio 822123 -1870 - Recte 81 3059-5600 - Joso Pessoa 83 2106-6221 - Natal 84 3615-1740 - Fortaleza 85 3462-1700 Sáo Luis 98 4009-2800 - Teresina $862106-3400$ - Betem $913184-8484$ - Manaus 91 2123-1100 - Porto Vetho 69 3026-5353 - Macapd 96 2101-6600 - Rio Branco $683223-000$ wwrw.crccom br ou consulte seu agente de viagens.

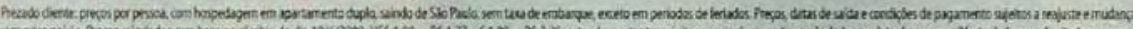

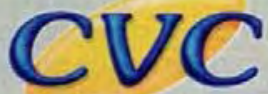

Sonhe com o mundo. A gente leva vocé.

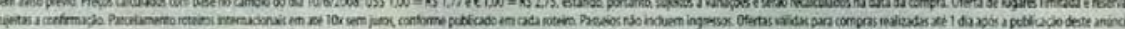

Propaganda 01 - Série “Turismo” - Revista Veja 23/07/2008 


\section{Férias em Bariloche}

\section{Ponte aérea CVC - TAM}

\section{A maior e mais completa infra-estrutura espera por você em Bariloche.}

0 inverno de Bariloche é 0 mais agitado da América Latina. Com a cidade tomada pela neve, casais, famílias e grupos de amigos enchem as estaçōes de esqui, os bares e os restaurantes da regiäo, muito procurada por brasileiros. A maioria deles levada pela CVC. E esse número vai aumentar. Agora, a CVC voa para lá todos os dias. Isso mesmo. Graças a uma parceria exclusiva entre a CVC, a TAM e a hotelaria da cidade, oferecemos vôos diários na temporada de julho. Você viaja nos modernos Boeing 767-300 da TAM, nos melhores horários, saindo de São Paulo pela manhā e retornando à tarde. Em Bariloche, você vai encontrar uma completa estrutura CVC a seu dispor. Equipe de guias especializados, frota própria de veiculos modernos para traslados e passeios, loja de atendimento no aeroporto e no Cerro Catedral. Resumindo: o conforto e a segurança que só a maior operadora de turismo da América Latina pode oferecer.

\section{Bariloche Clássico Apartirde}

\section{Roteiro para quem quer curtir e passear} 10x R 298 ,

Incluialuguei de roupa especial paranevedurante 6 dias, passeio pelacidade, ingresso ao teleférico do Cerro Campanário e ponto panoràmico, passeio ao Cerro Catedral e visita a uma tradicional fábrica dos famosos chocolates de Bariloche, 1 ingresso para o cassino de Bariloche, 1 revista de viagem com informaçōes úteis da regiāo e 1 livro por familia com fotos de Barilochee do Parque Nacional de Nahuel Huapi. Hotel Postal del Lago. A vista RS 2.980, Base USS 1.618, Preço para saida 28/junho.

\section{Bariloche Total Apartide}

\section{Roteiro para quem quer passear e aprender a esquiar}

Com as mesmas inclusóes do Bariloche Clássico e mais 2 horas/aula de esqui nas pistas de principiantes com equipamentos incluidos (esquis, botas e bastōes), passeio a Villa La Angostura com almoço, passeio ao Cerro Otto com ingresso para o teleférico, passeio de barco a litha Victória e passeio a o Parque Nacional Nahuel Huapi 1 jantar especial de cortesia.

Hotel Postal del Lago. A vista RS 3.420, Base USS 1.858, Preço para sáda 28/junho.

\section{Coloque na tela do seu computador uma foto que você mesmo tirou.} Para todo mundo, existe uma CVC.
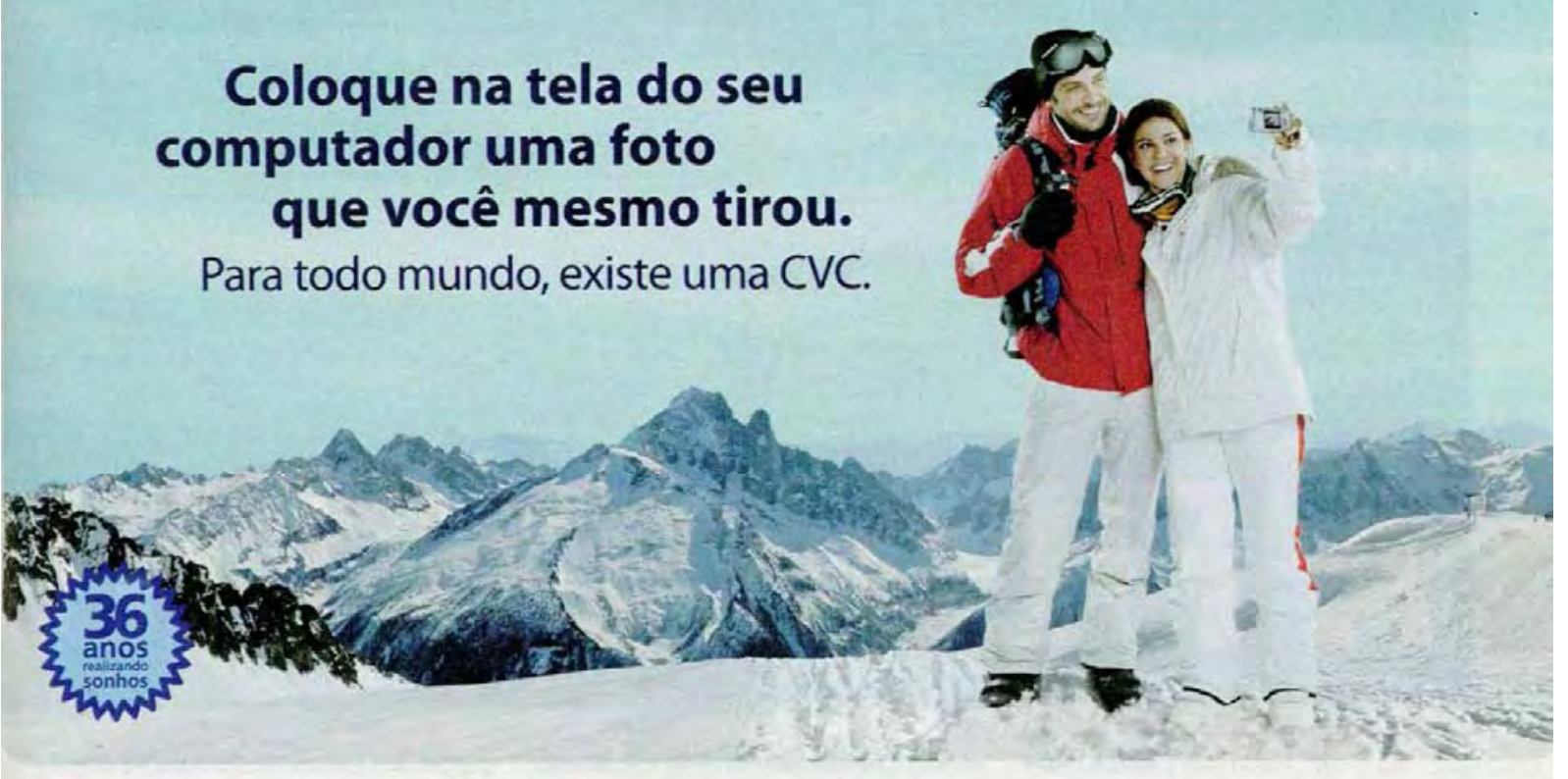

Visite uma loja CVC nos melhores shoppings do Brasil ou, se preferit, ligue: Sao Paulo 11 2146-7011/2103-1222 - Santo Andre 11 2191-8700 - Sao Bernardo 11 2191-3500 Sajo Caetano 11 3636-3450 - Maud 11 4519-4700 - Diadema 11 4043-2928 - 05asco 11 3699-9909 - Campinas 192117-3500 - Mogi das Cruzes 11 4799-2166 - Suzano 112148 -4600 Suarulhos $116425-0533$ - Santos $133257-7000$ - Jundiai 11 4522-3088 * Bauru $142106-9494 \cdot 5$, I. dos Campos $123878-7000$ - Taubate 123411 - 5000 - Araraquara

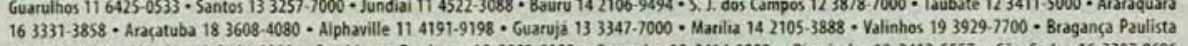

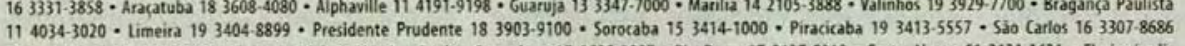
Ribeiräo Preto $162101-0048$. Bbitinga 16 3341-8210. Garden Catanduva 17 3525-2097 - Rio Preto 17 2137-5910. Porto Alegre 51 2121-1621. Florianopolis

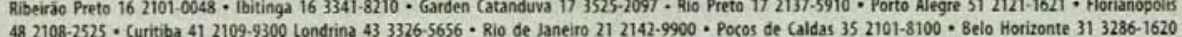
$482108-2525$ - Curitiba $412109-9300$ Londrina $433326-5656$ - Rio de laneiro $212142-9900$ - Pocos de Caicas $352101-8100$ - Belo Hotizonte 31 3280-1620 Uberiándia $342101-5200$ - Vitória $272122-8222$ - Braslila 61 3234-0446 - Goiänia 62 4005-8900 - Campo Grande 67 3323-5100 - Cuiaba 65 3316-4600 - Salvador

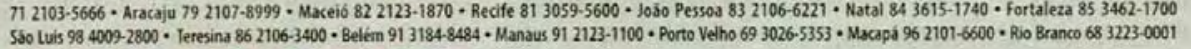
Www.cuc.com. br ou consulte seu agente de viagens.

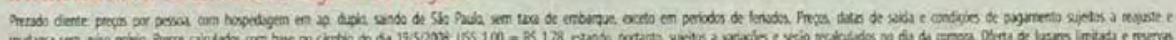

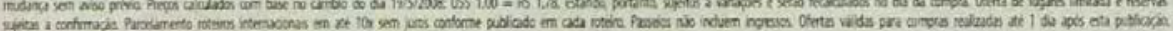

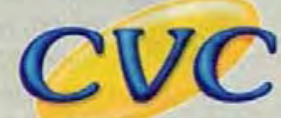

Sonhe com o mundo. A gente leva você.

Propaganda 02 - Série “Turismo" - Revista Veja 11/06/2008 


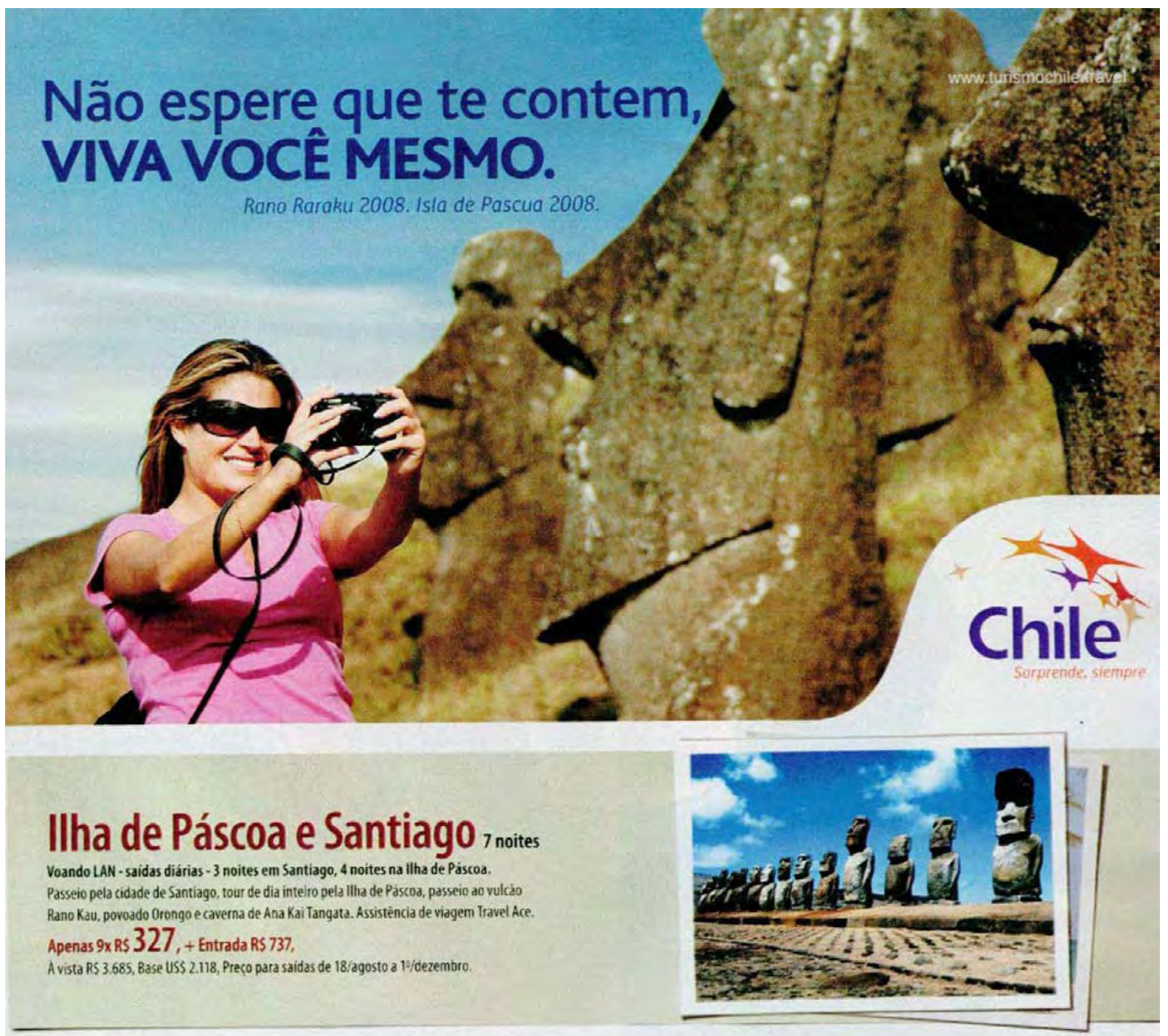

Santiag0 2,3 e 4 noites Apenas. $9 \times \operatorname{RS} 100$. Hotel Principade

Voando TAM - saidas diárias. Moderna e vibrante, a capital chilena vem atraindo cada vez mais visitantes em busca de novidade e também de paisagens incriveis da corditheira que emoldura o horizonte. Entrada RS 225 , A vista RS 1.127, Base USS 648 ,

Preço de 2 noites para saidas de 18/agosto a 1//dezembro.
Santiago e Viña del Mar 7 noites Apenas.__. $9 \times$ R $\$ 261$, Voando LAN- -saidas diarrias - 4 noites em Santiagoe 3 noites em Viña del Mar. City tour panorámico em Santiago, passeios em Viña del Mar. Valparaiso, Isla Negra com entrada para o Museu Pablo Neruda, passeio ao vinhedo com almoço incluido e assistència de viagem Iravel Ace. Entrada RS 587, A vista RS 2.937, Base USS 1.688, Preço para saidas de 18/agosto a T/dezembro.

Visite unna loja CVC nos melhores shoppings do Brasil ou, se preferit, ligue: Sảo Paulo 11 2146-7011/2103-1222 - Santo Andre $112191-8700$ - Sà Bermardo $112191-3500$ Sảo Caetano 11 3636-3450 - Maua 11 4519-4700 - Diadema 11 4043-2928 - Osasto $113699-9909$ - Campinas 192117-3500 • Mogi das Cruzes $114799-2166$ Suzano $112148-4600$ - Guarulhos 11 6425-0533 * Santos $133257-7000$ • Jundiai 11 4522-3088 • Bauru 142106-9494 - 5. I. dos Campos $123878-7000$ - Taubate $123411-5000$ Araraquara $163331-3858$ - Aracatuba 18 3608-4080 - Alphaville 11 4191-9198 - Granja Viana 11 4702-0306 - Guaruja $133347-7000$ - Marilia 142105 - 3888

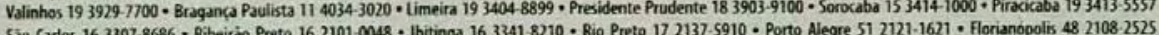

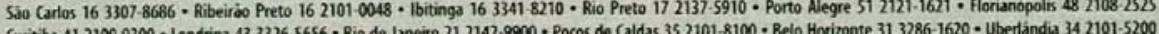
Curitiba 412109.9300 - Londrina $433326-5656$ - Rio de laneiro $212142-9900$ - Pocos de Caldas $352101-8100$ - Belo Horizonte $313286-1620$ - Uberlandia $342101-5200$ Vitoria 27 2122-8222 - Brasilia 61 3234-0446 - Goiánia 62 4005-8900 - Campo Grande 67 3323-5100 - Cuiaba 65 3316-4600 - Salvador 71 2103-5666 Aracaju 79 2107-8999 - Maceió 82 2123-1870 - Recife 81 3059-5600 - Joào Pessoa 83 2106-6221 - Natal 84 3615-1740 - Fortaleza 85 3462-1700 Sá Luis 98 4009-2800 - Teresina 86 2106-3400 - Belém 91 3184-8484 - Manaus 91 2123-1100 - Porto Velho 69 3026-5353 - Macapa 962101 - 6600 - Rio Branco 68 3223-0001

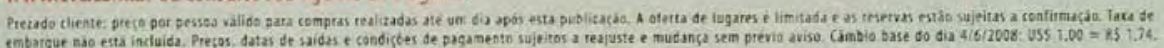

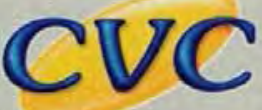

Sonhe com o mundo. A gente leva voce. 


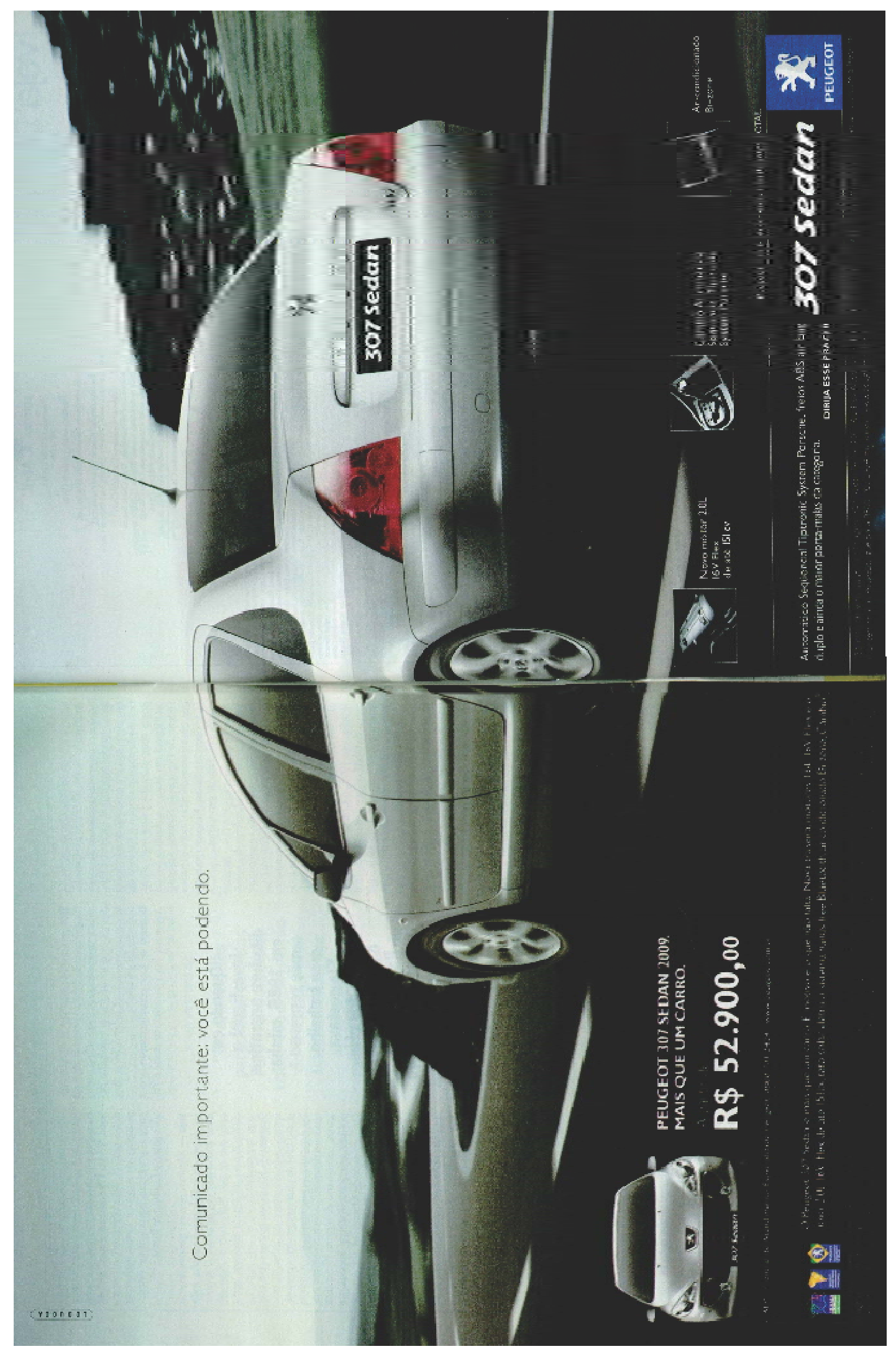

Propaganda 04 - Série "Carros e Motocicletas" - Revista Veja 23/07/2008 


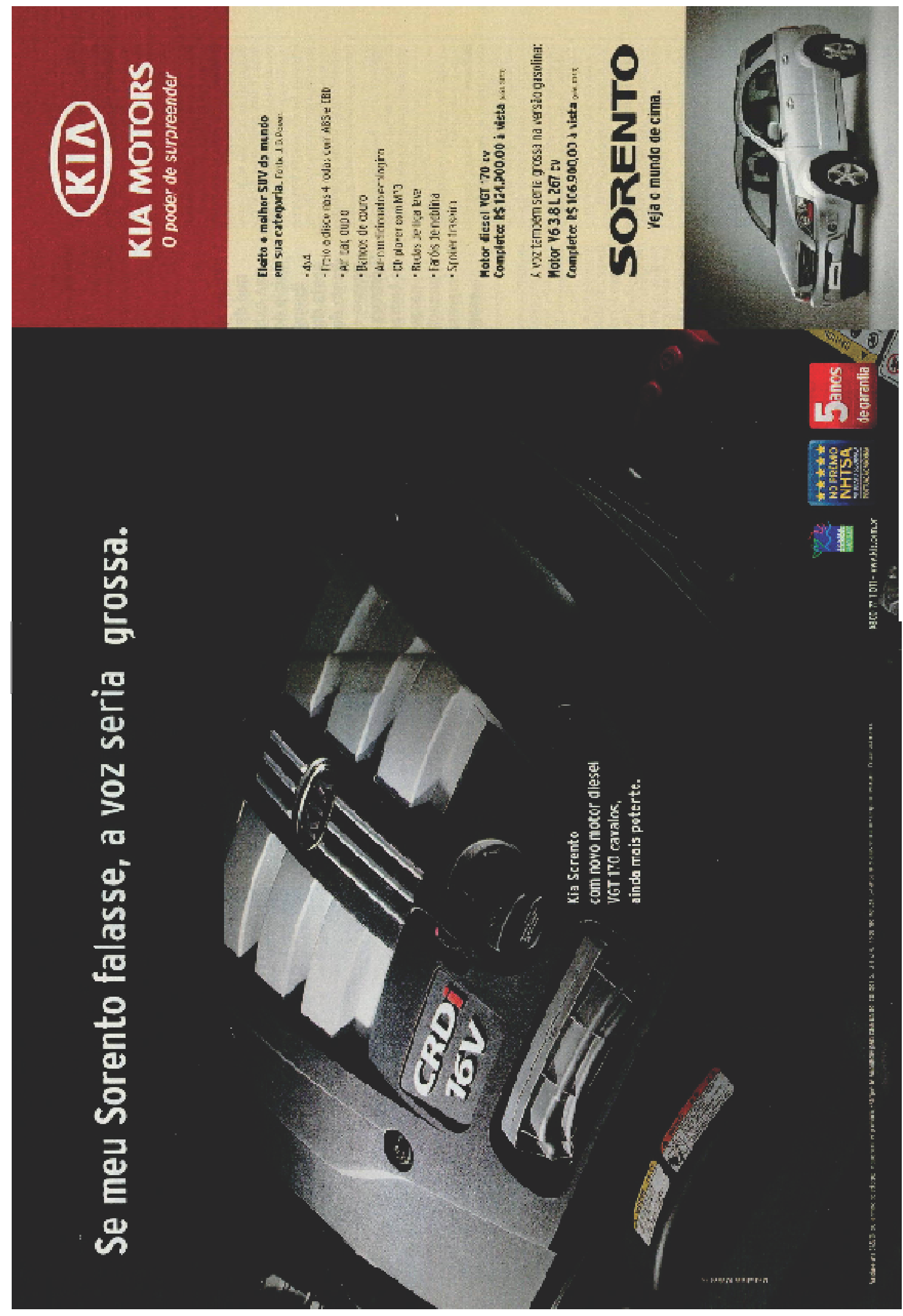

Propaganda 05 - Série "Carros e Motocicletas" - Revista Veja 25/05/2008 


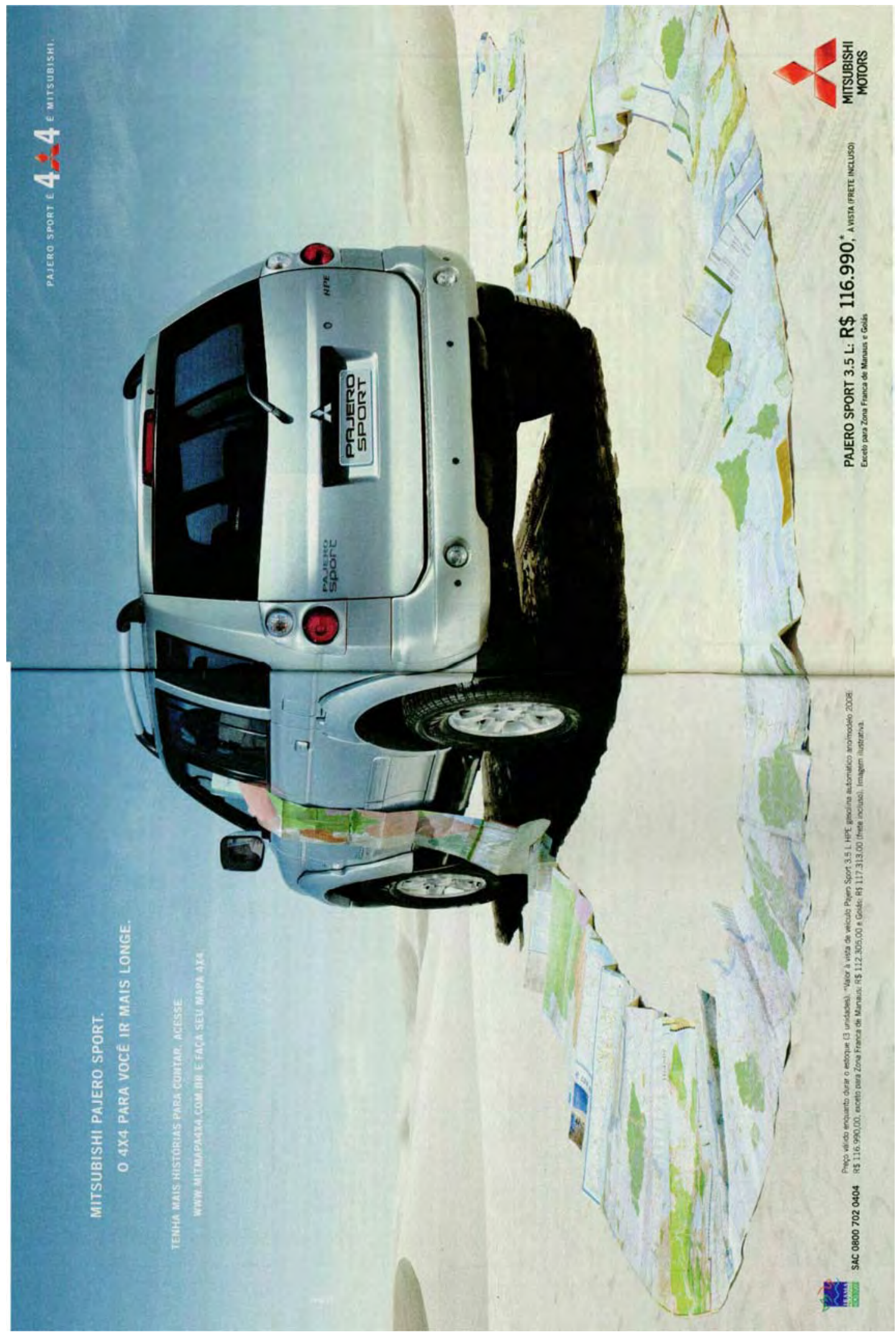

Propaganda 06 - Série "Carros e Motocicletas" - Revista Veja 11/06/2008 


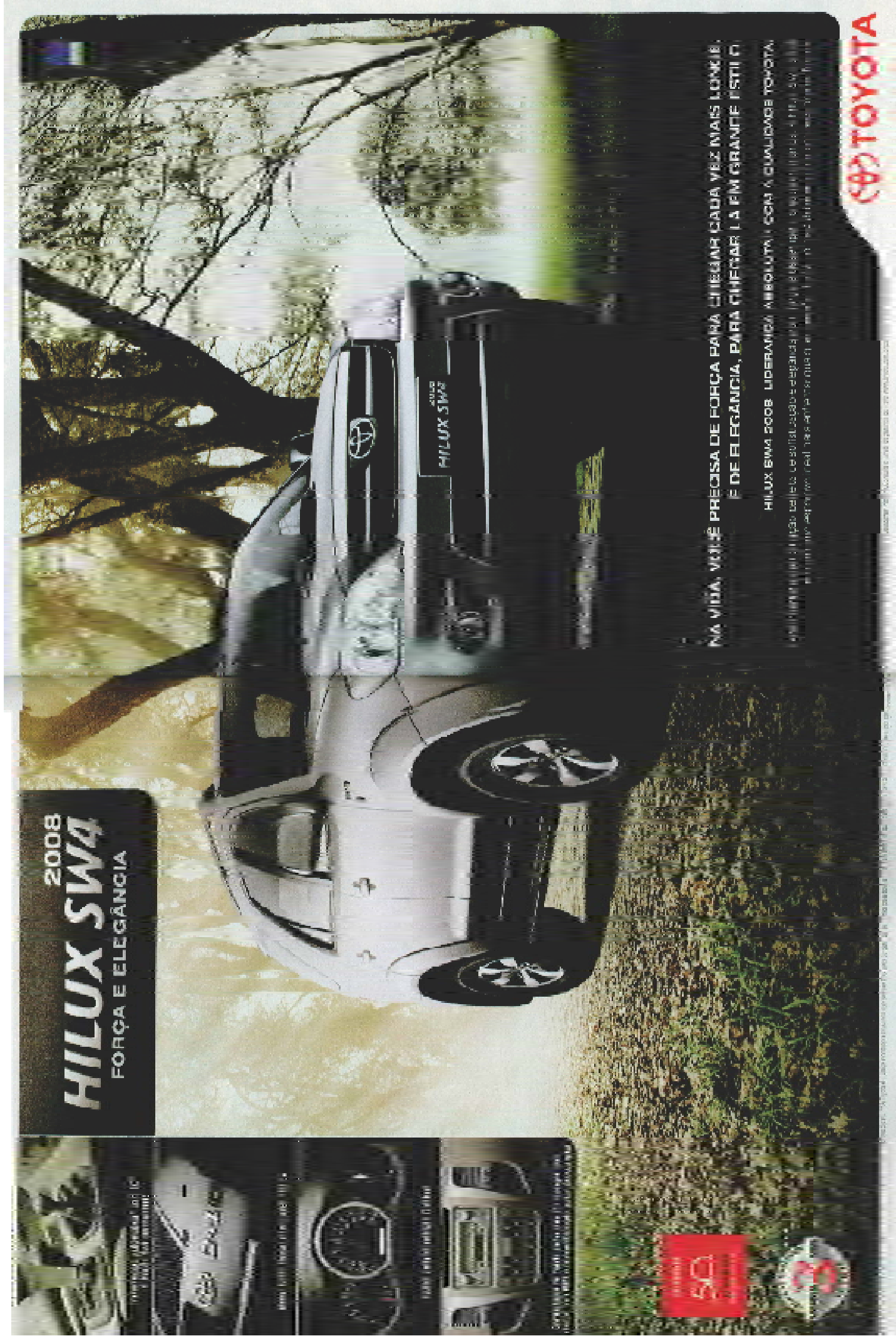

Propaganda 07 - Série “Carros e Motocicletas” - Revista Veja 11/06/2008 


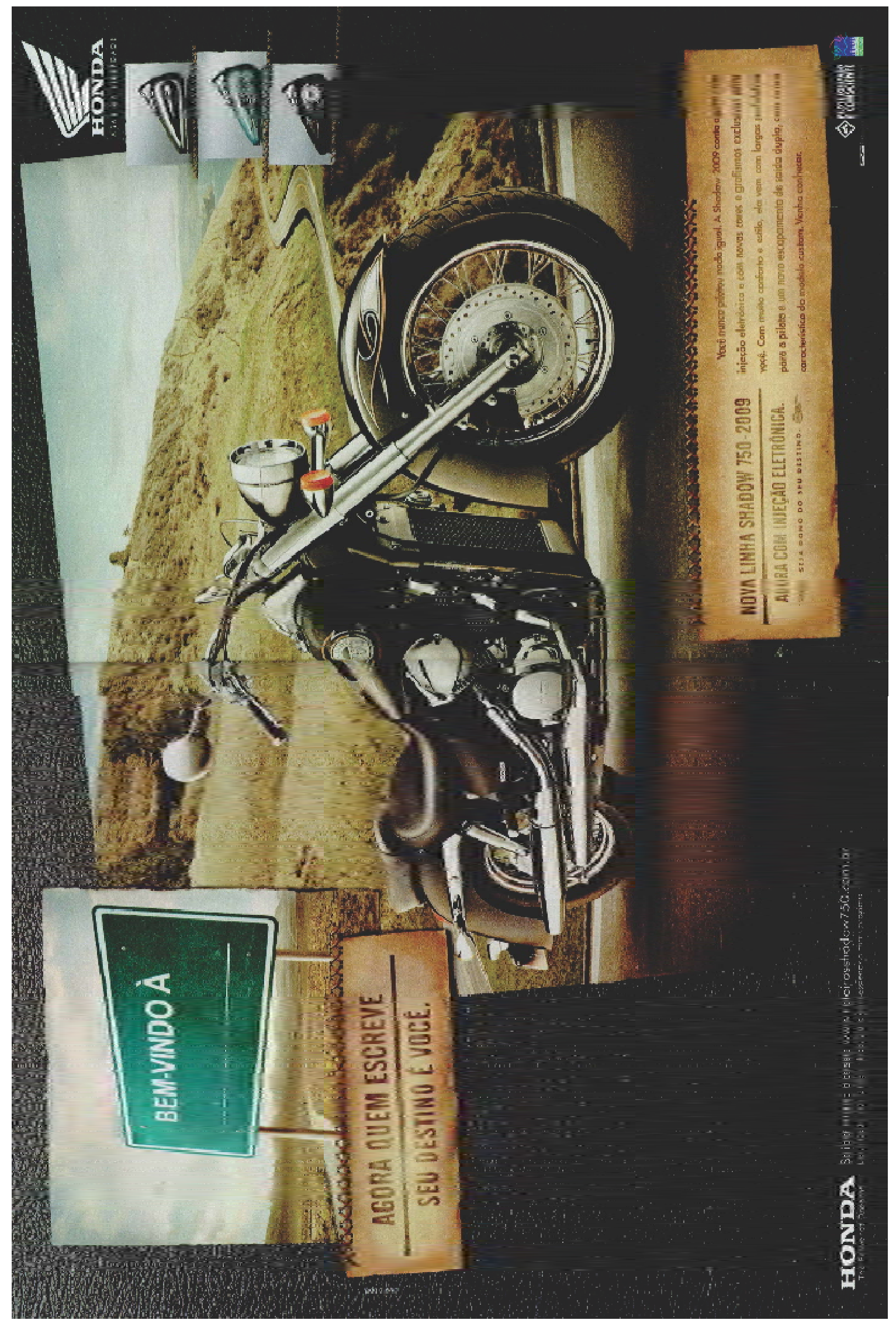

Propaganda 08 - Série “Carros e Motocicletas" - Revista Veja 04/06/2008 


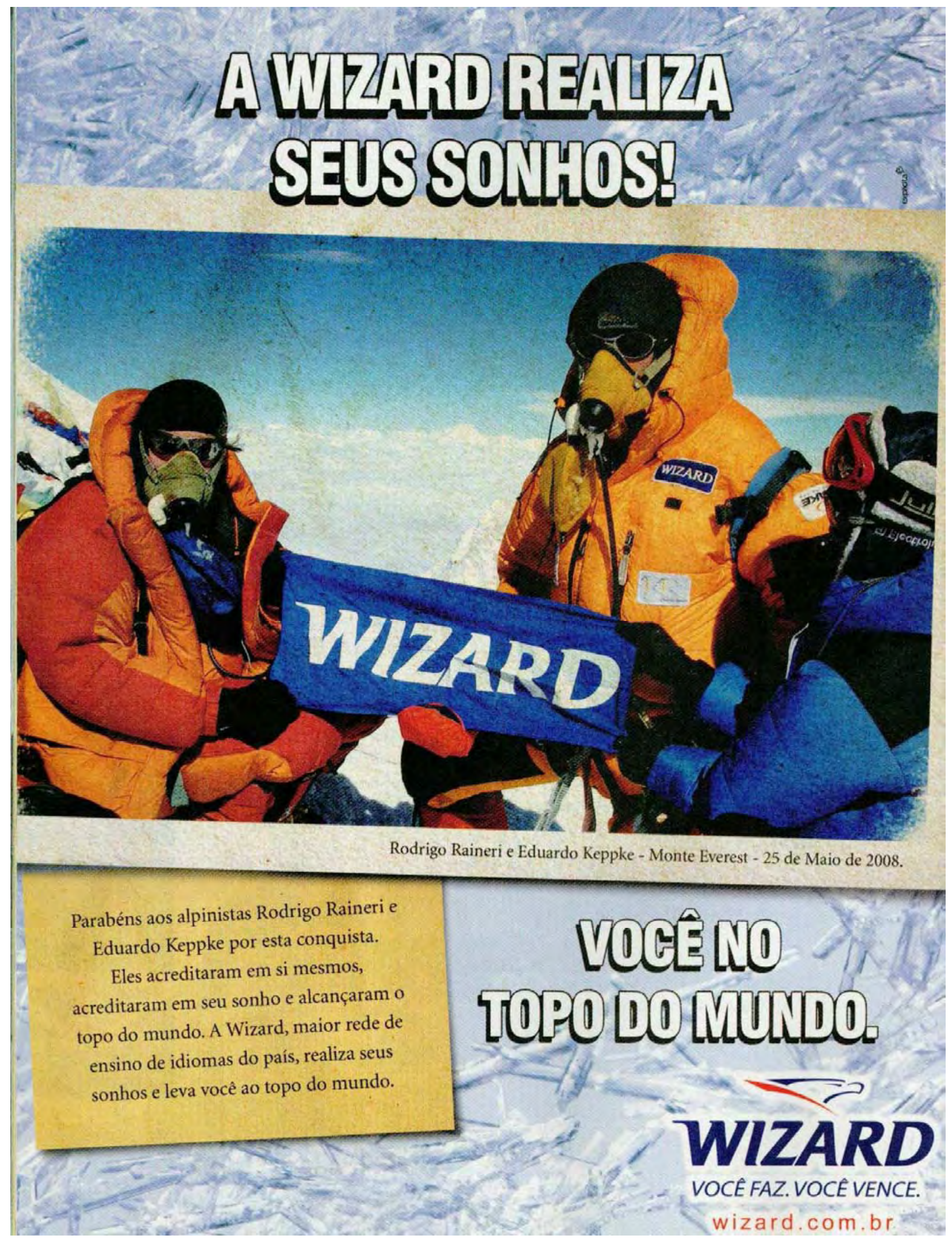

Propaganda 09 - Série "Serviços" - Revista Veja 16/07/2008 


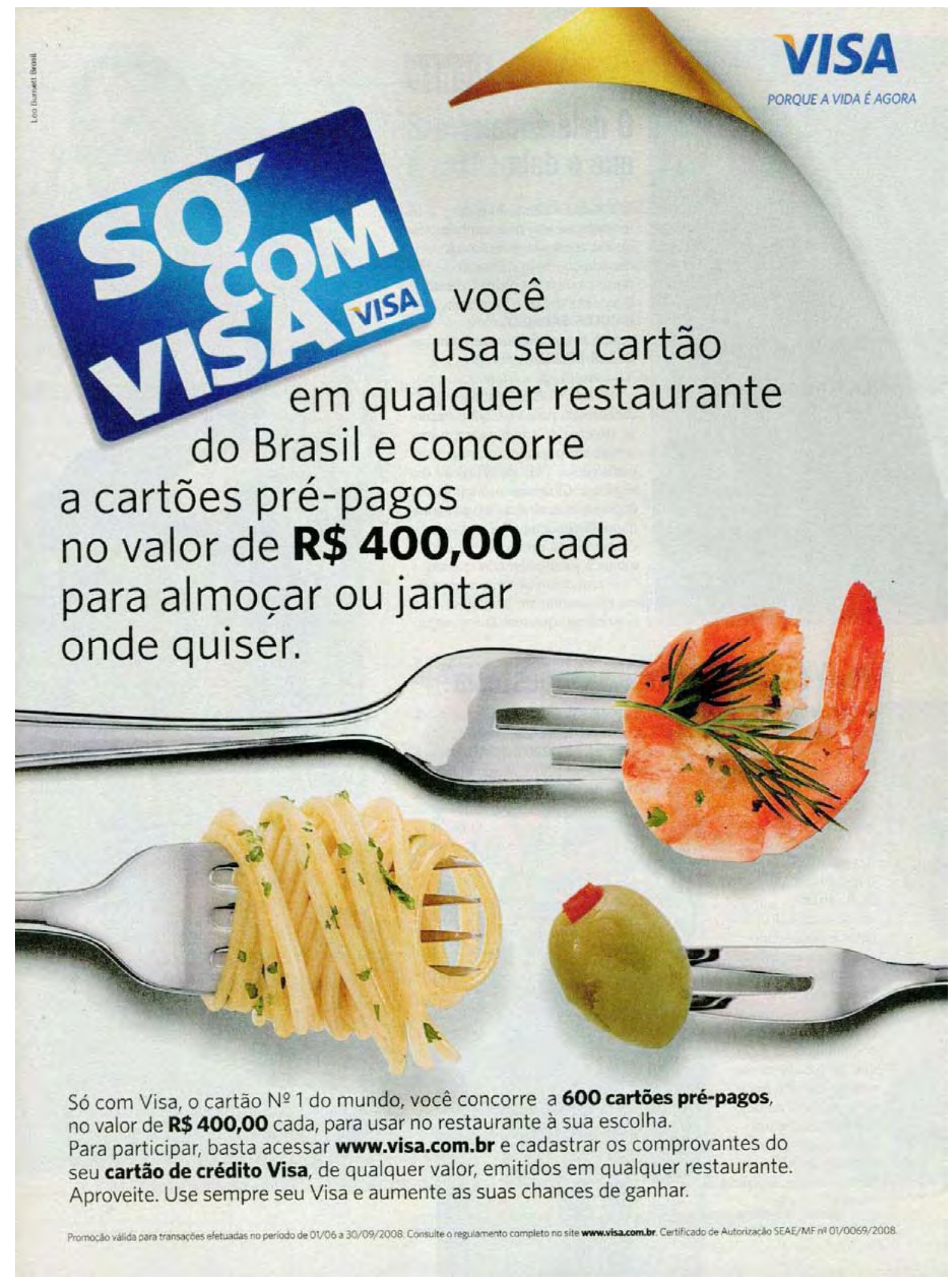

Propaganda 10 - Série "Serviços" - Revista Veja 11/06/2008 


\section{Seguro Auto Mulher}

SulAmérica. Porque quem tem que suar são os homens.
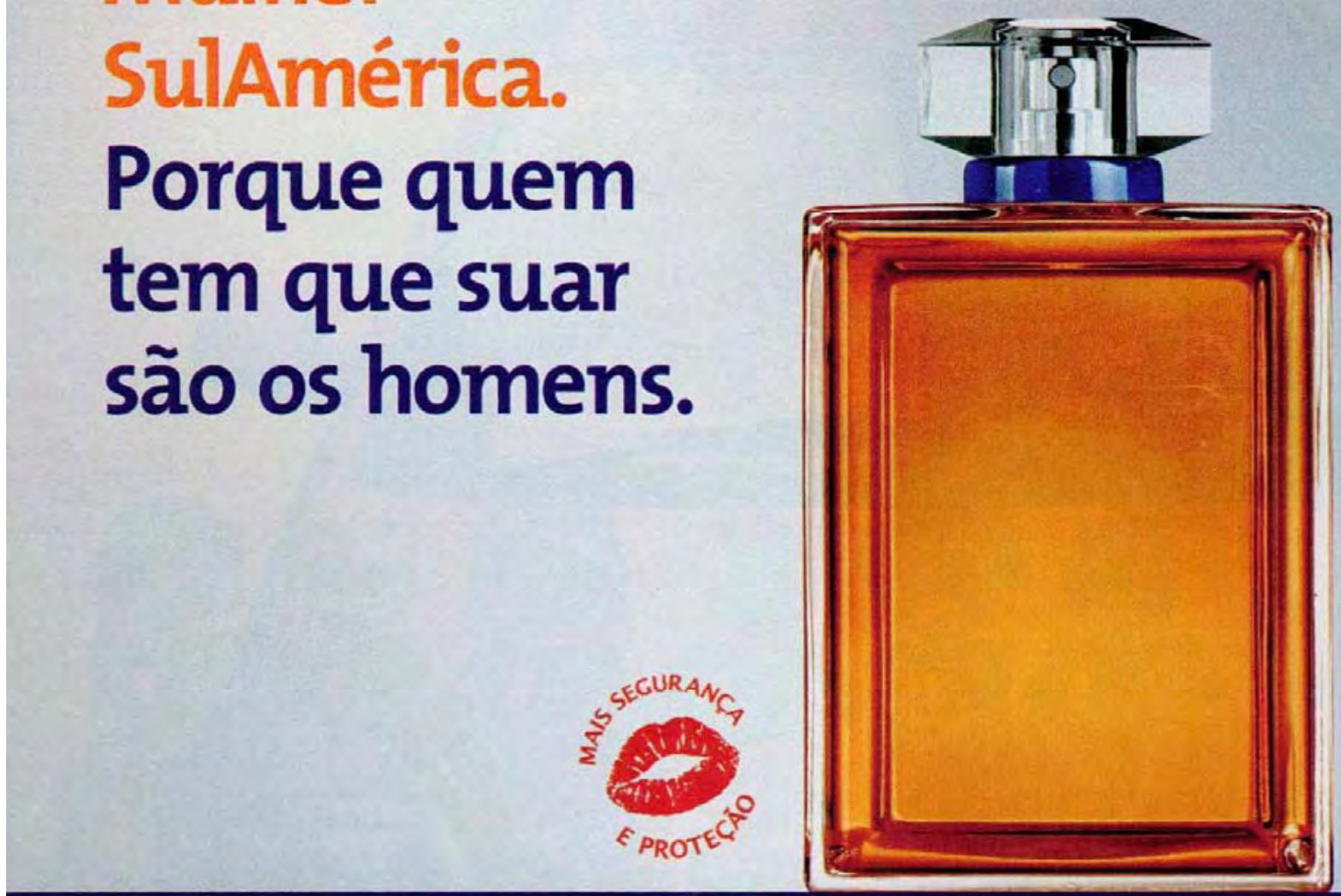

\section{Troca de pneu 24 horas sem limite de utilização.}

O único com franquia zero: se acontecer, a primeira batida é por nossa conta.

E mais: - Em caso de roubo ou furto, um acompanhante vai com você até a delegacia - Auxilio-Reboque em caso de pane sem limite de utilização. Após a meia-noite, o Motorista Amigo leva você até a sua casa. - Central exclusiva de atendimento - E mais todas as vantagens de ser cliente SulAmérica Auto.

O seguro pensado por e para mulheres.

Consulte seu corretor de seguros ou informe-se: 40044937 (capitais e regiōes metropolitanas) 08007264937 (demais regiōes)

SulAmérica associada ao ING AD

Propaganda 11 - Série "Serviços” - Revista Veja 14/05/2008 


\section{Seguro Auto}

Mulher SulAmérica.

\section{Não deixa você}

a pé porque sabe que você anda de salto alto.
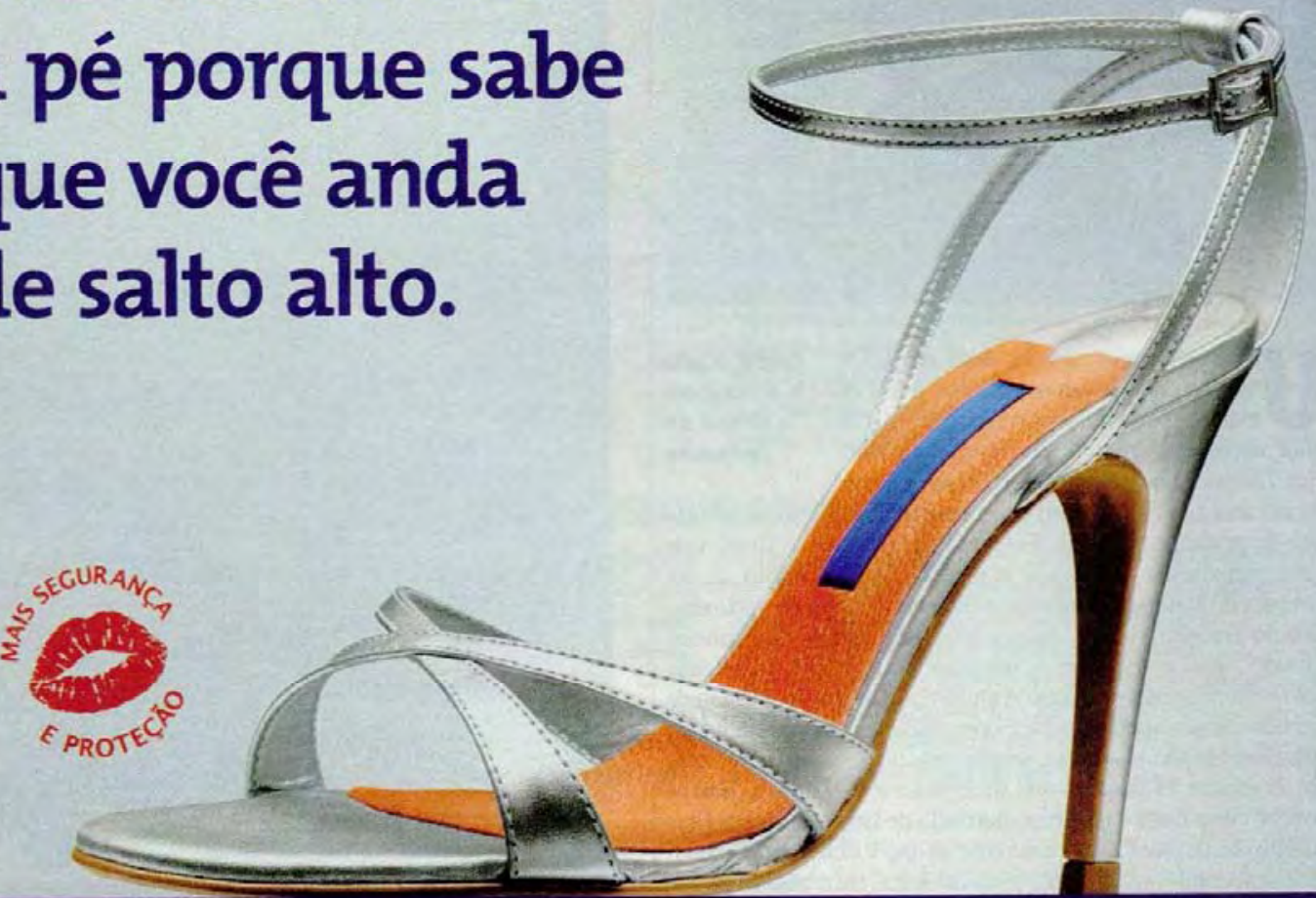

(t)

\section{Auxilio-Reboque em caso de pane sem limite de utilização.}

O único com franquia zero: : se acontecer, a primeira batida é por nossa conta.

E mais: - Em caso de roubo ou furto, um acompanhante vai com vocè até a delegacia - Troca de pneu 24 horas sem limite de utilização. Apos a meia-noite. o Motorista Amigo leva você até a sua casa. Central exclusiva de atendimento. E mais todas as vantagens de ser cliente SulAmerica Auto.

O seguro pensado por e para mulheres.

Consulte seu corretor de seguros ou informe-se: 40044937 (capitais e regiōes metropolitanas)

\section{SulAmérica} associada ao ING ADid

Propaganda 12 - Série "Serviços" - Revista Veja 28/05/2008 


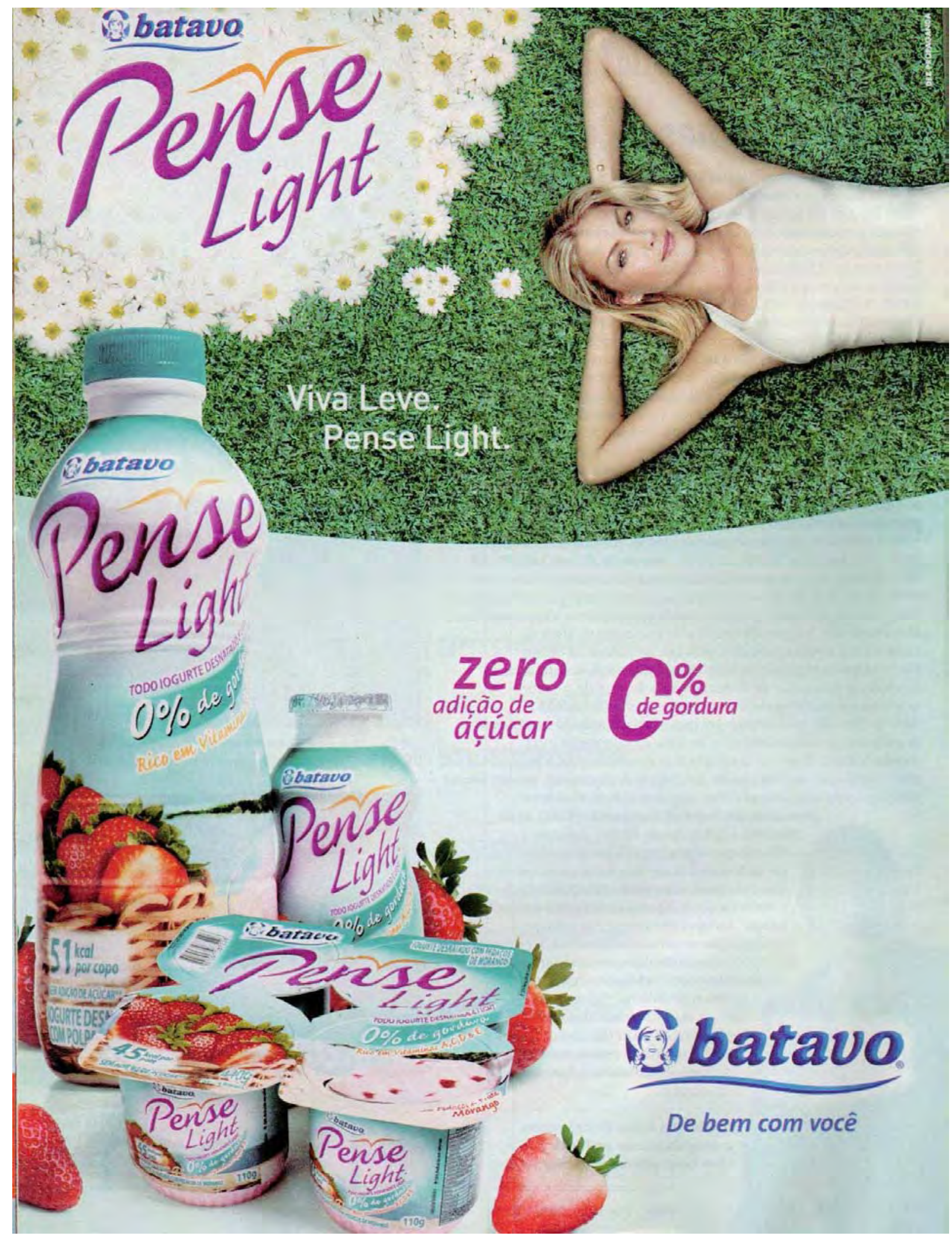

Propaganda 13 - Série “Cuidados Pessoais" - Revista Veja 02/07/2008 


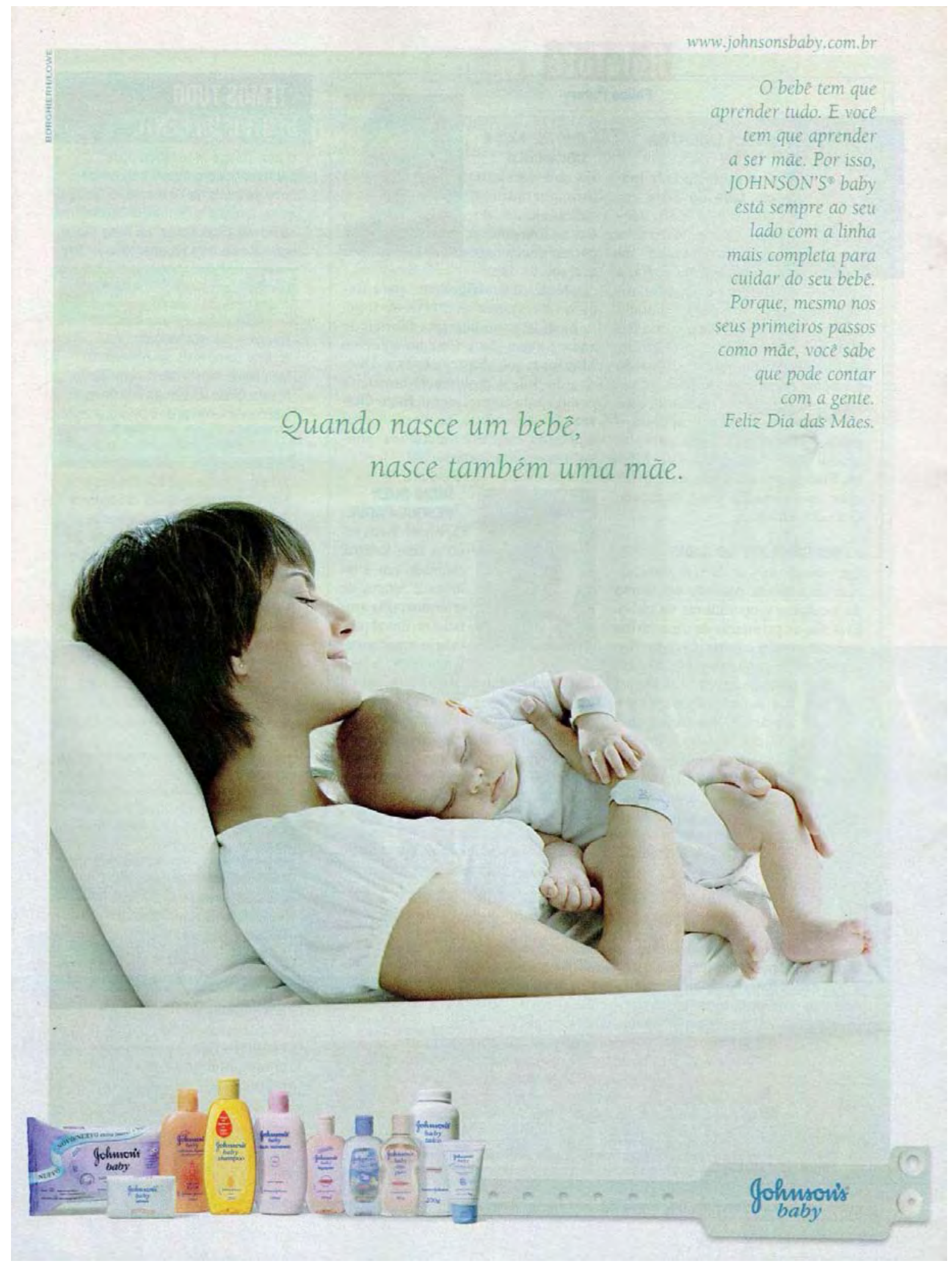

Propaganda 14 - Série “Cuidados Pessoais" - Revista Veja 14/05/2008 


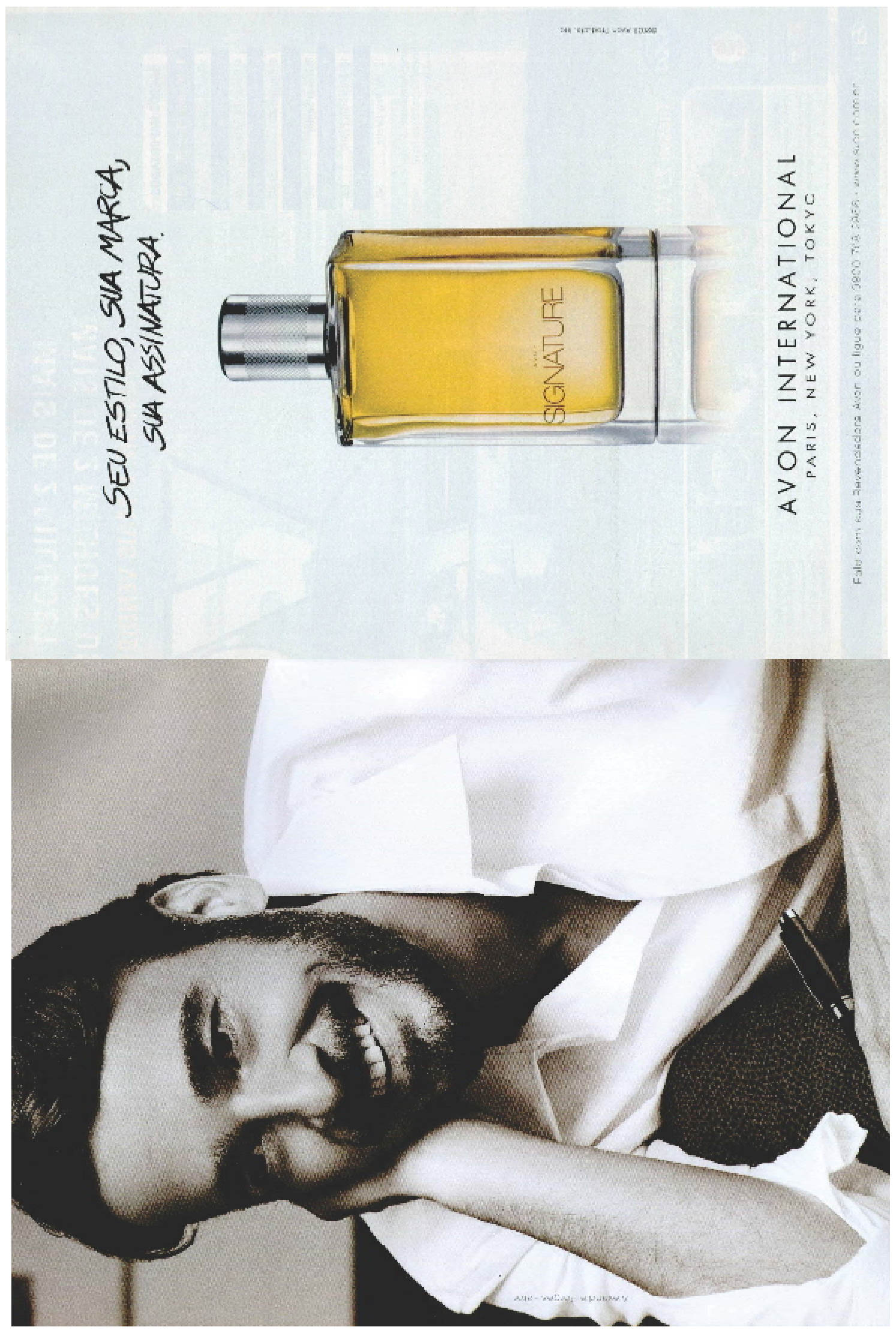

Propaganda 15 - Série "Cuidados Pessoais" - Revista Veja 25/06/2008 


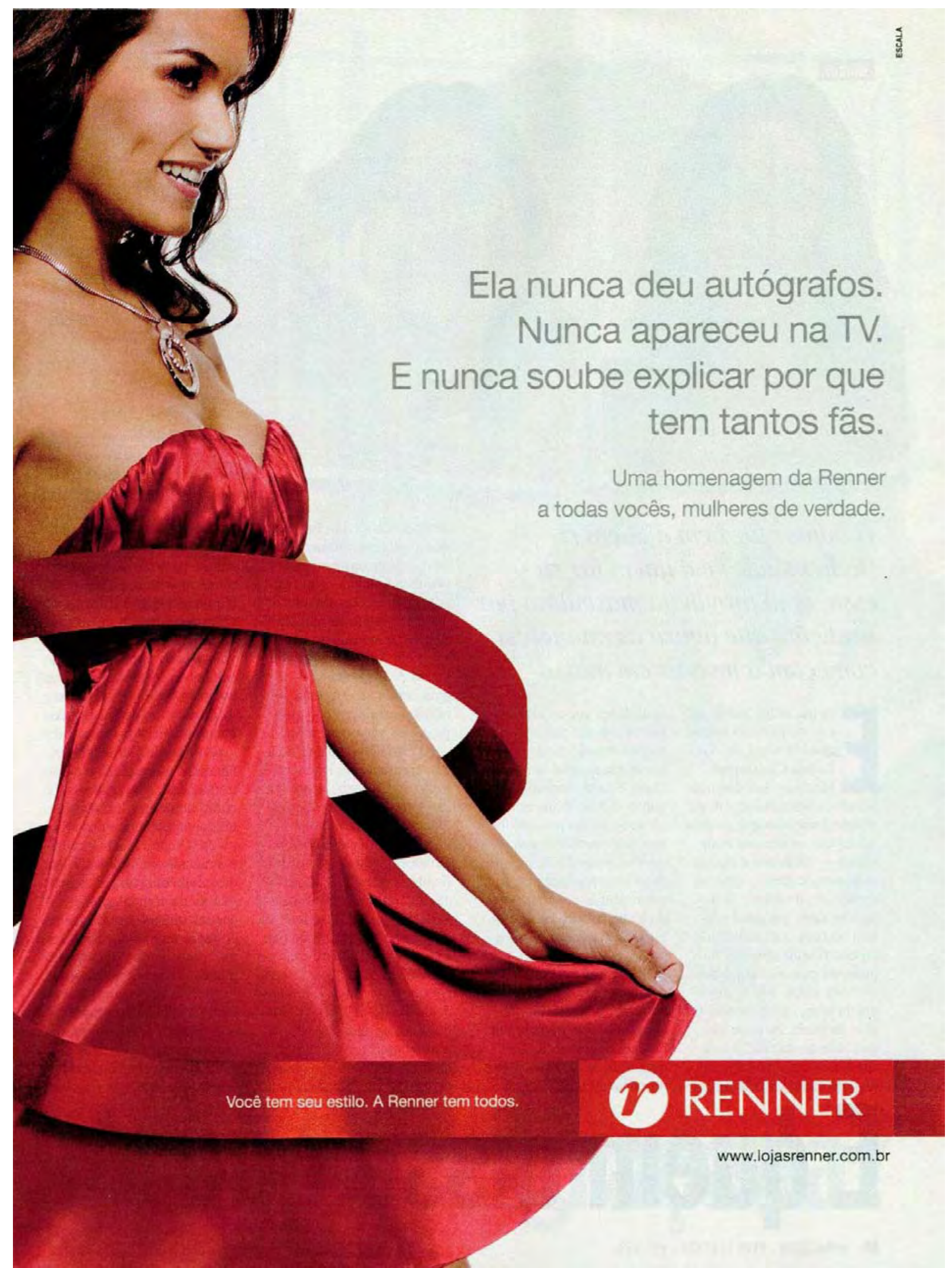

Propaganda 16 - Série "Cuidados Pessoais" - Revista Veja 25/05/2008 


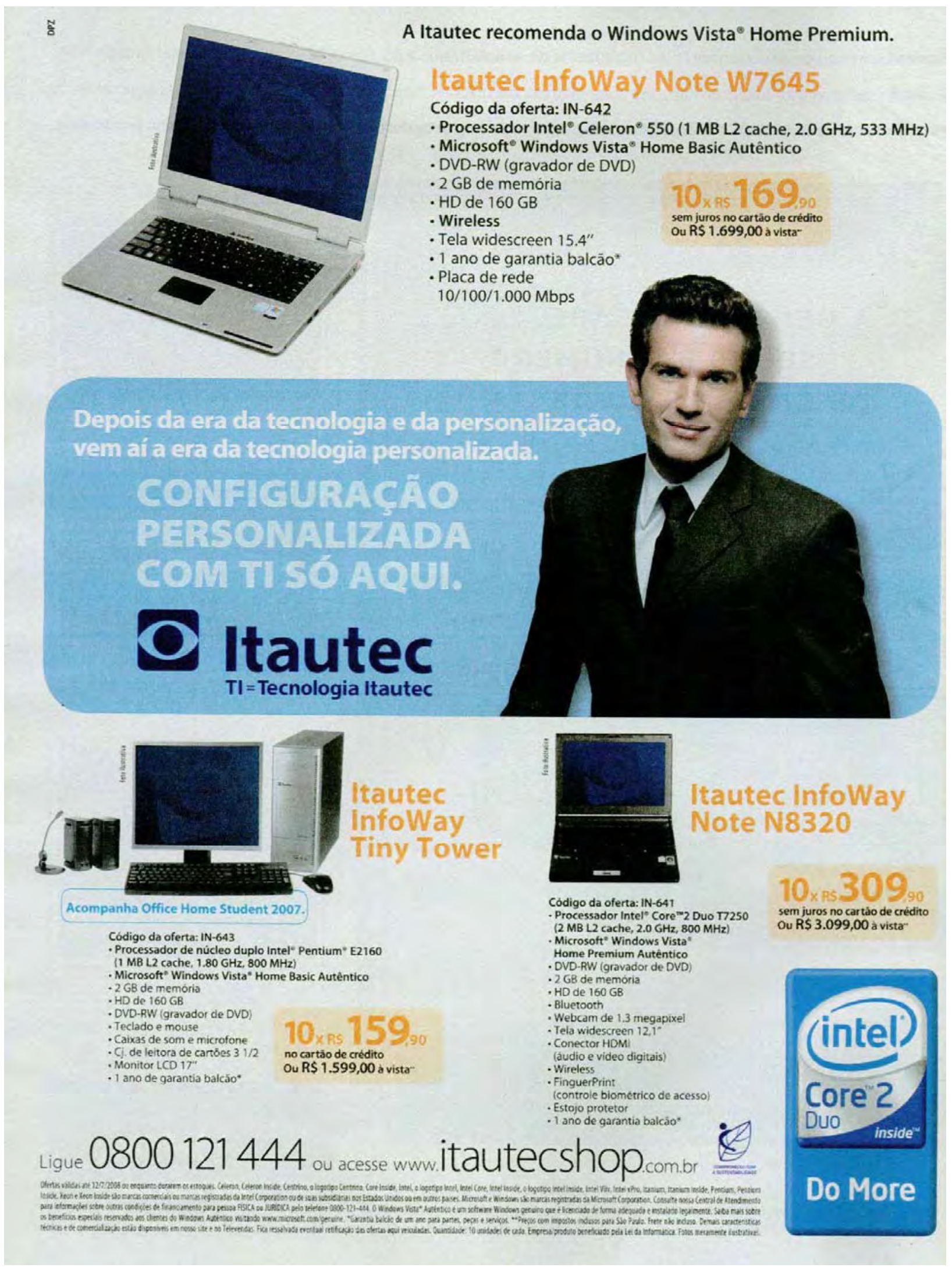

Propaganda 17 - Série “Tecnologia” - Revista Veja 09/07/2008 


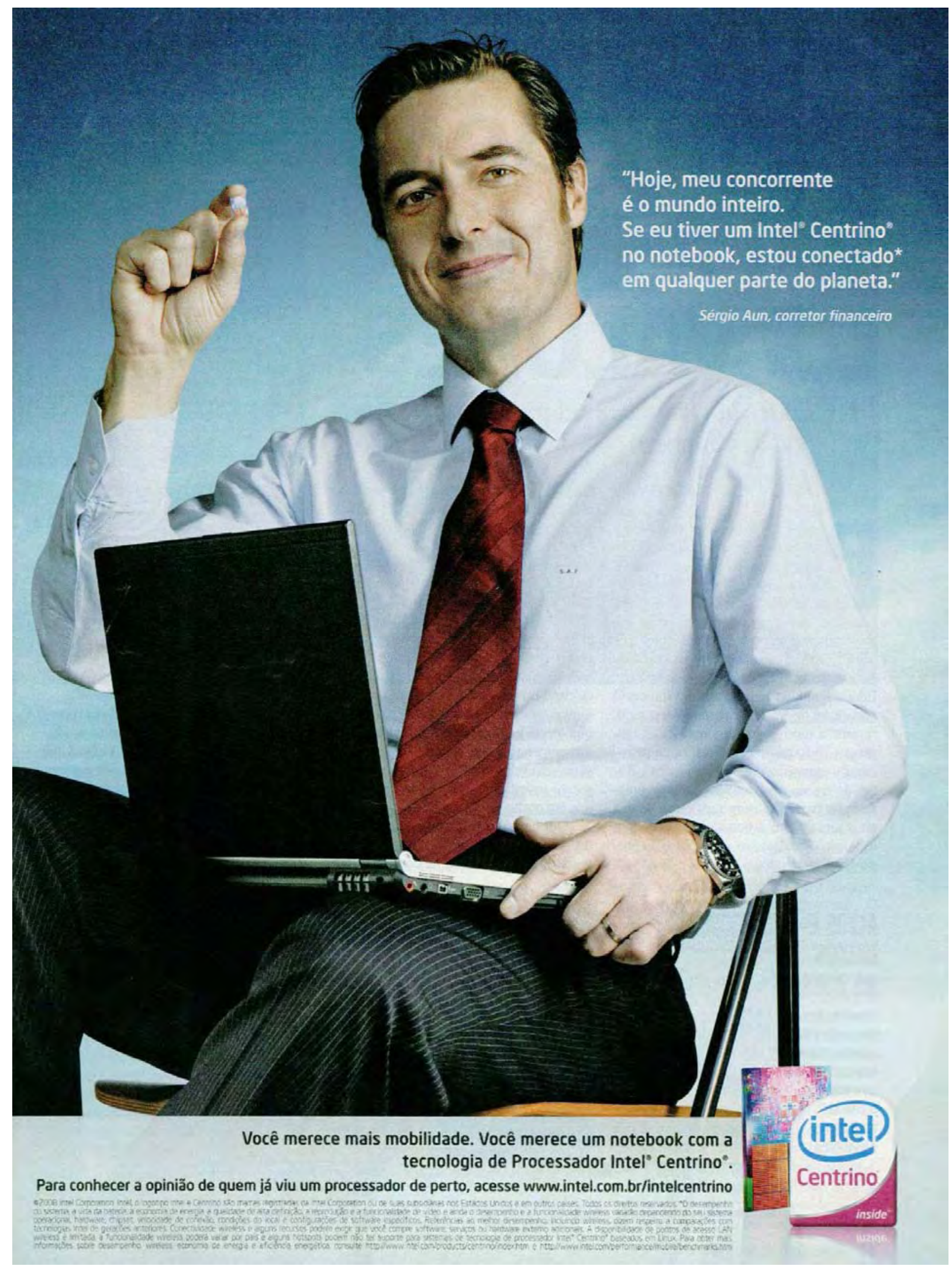

Propaganda 18 - Série "Tecnologia" - Revista Veja 02/07/2008 


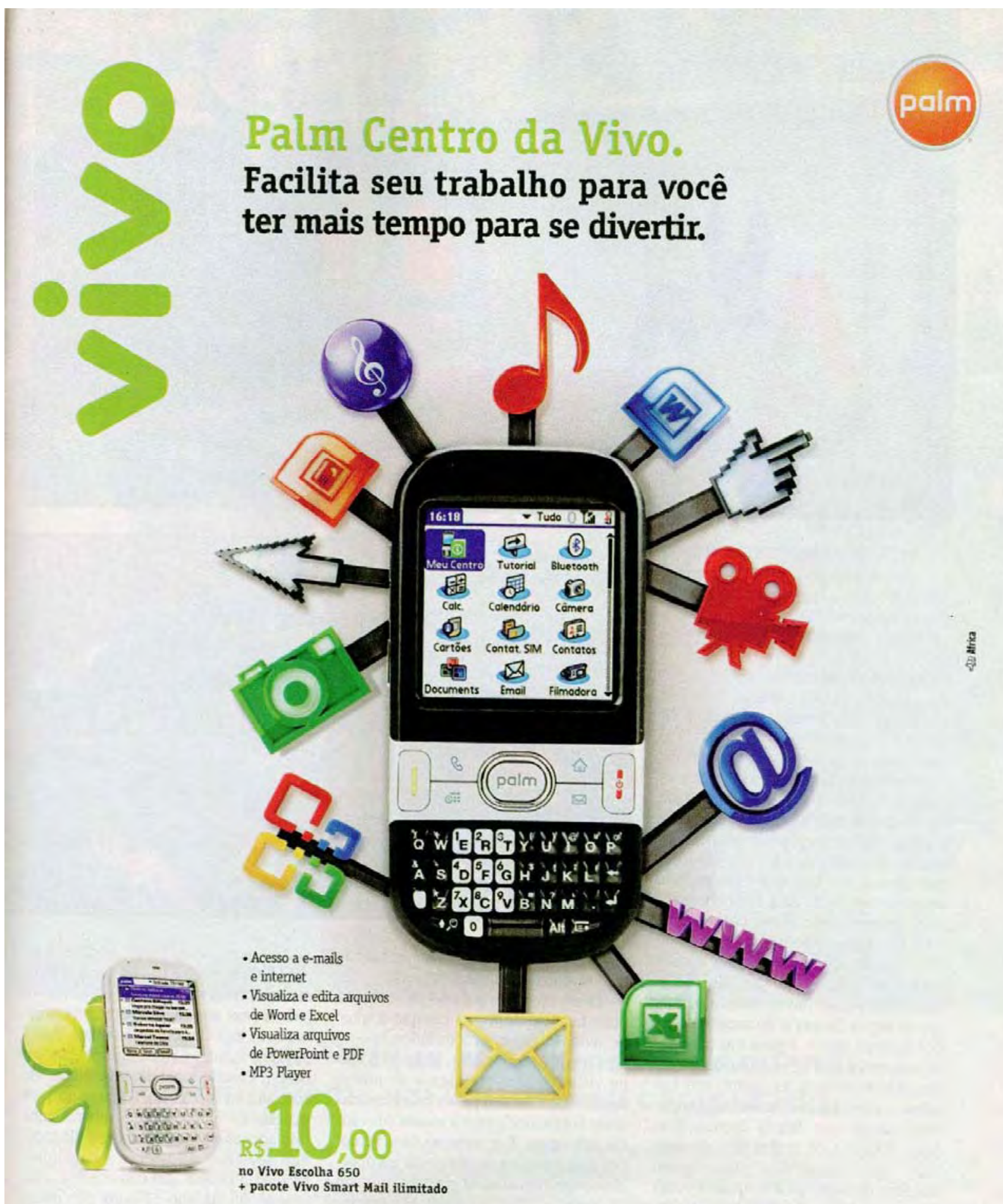

Vá até uma loja ou revendedor Vivo e compre o seu. www.vivo.com.br

vivo Sinal de qualidade.

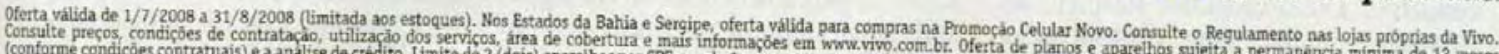

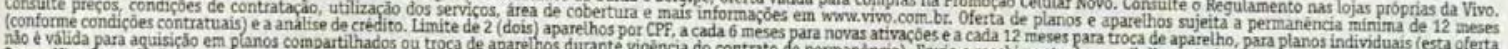

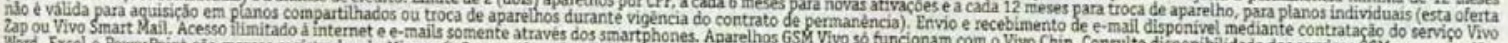

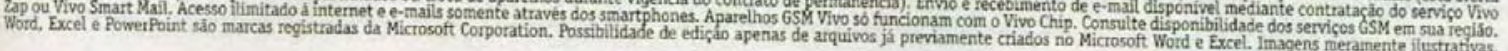

Propaganda 19 - Série “Tecnologia” - Revista Veja 30/07/2008 


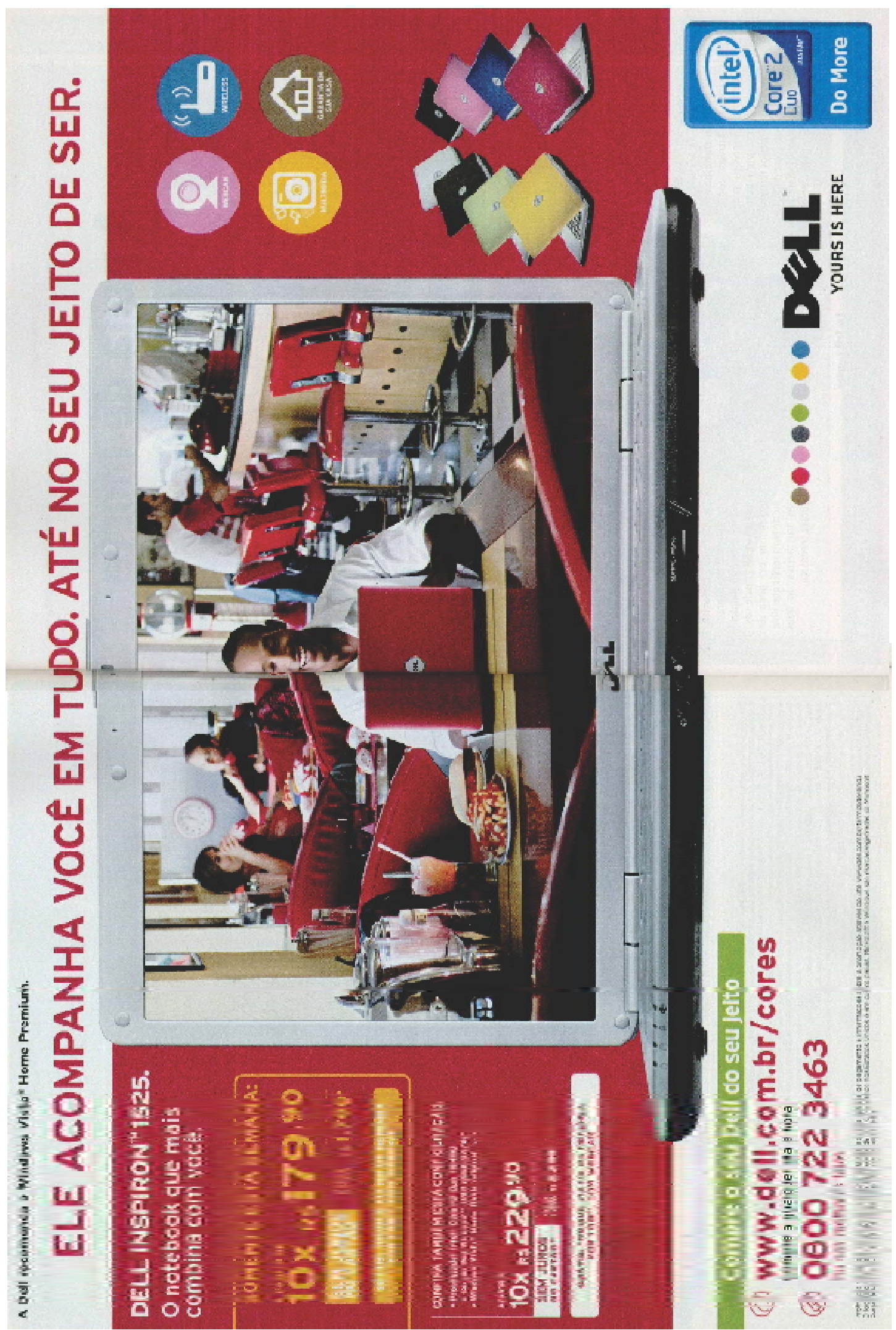

Propaganda 20 - Série “Tecnologia” - Revista Veja 28/05/2008 


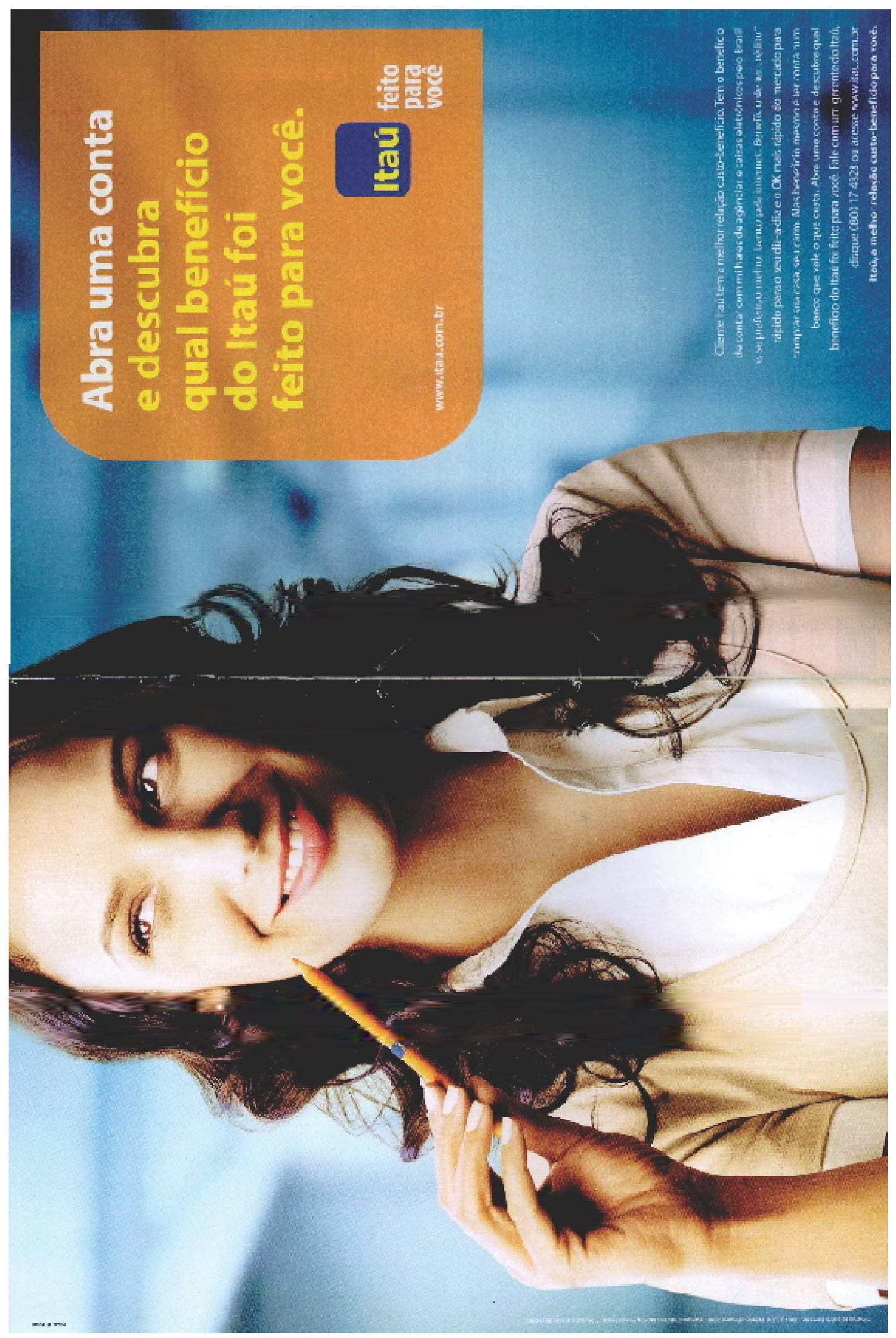

Propaganda 21 - Série "Bancos” - Revista Veja 23/07/2008 


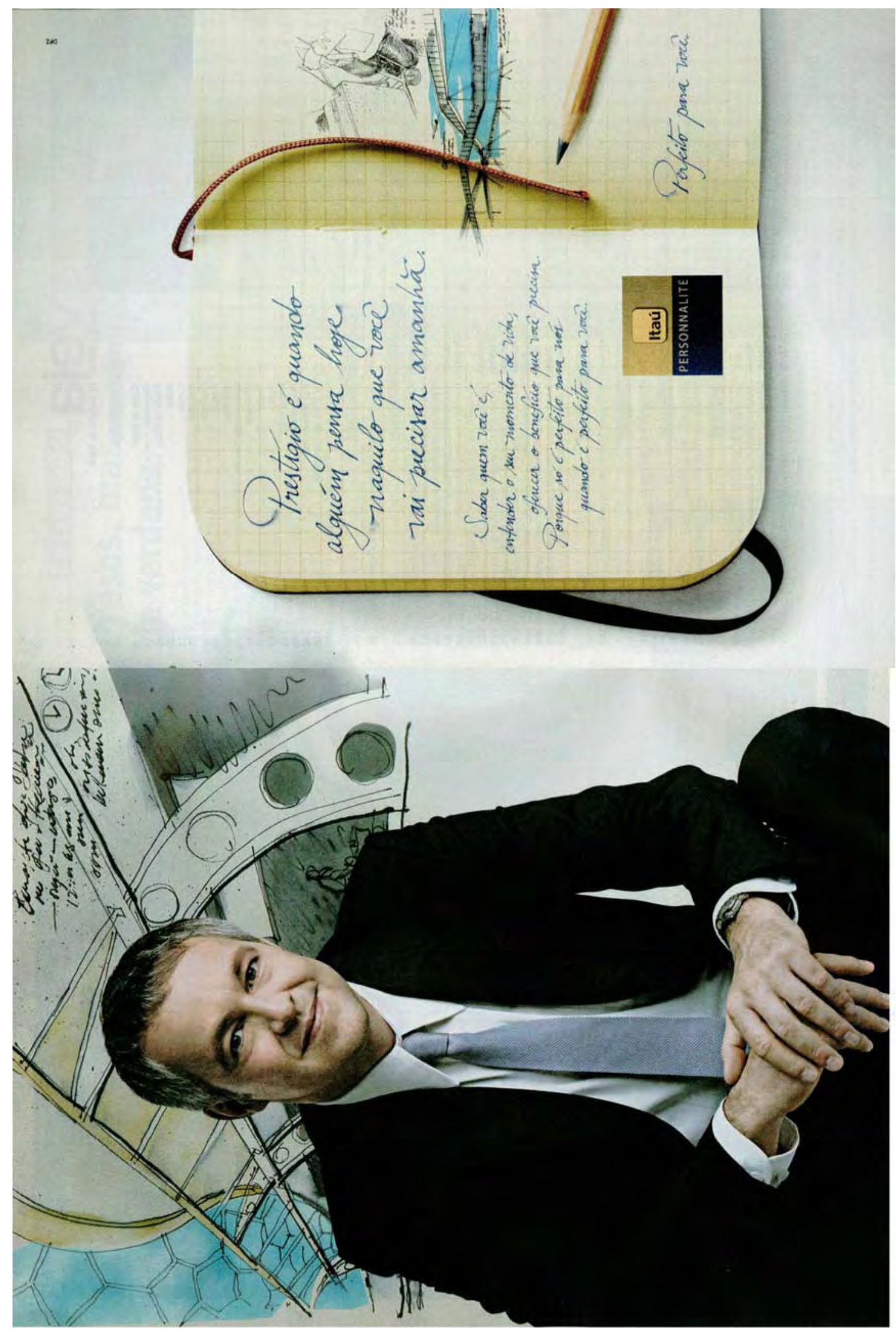

Propaganda 22 - Série "Bancos" - Revista Veja 16/07/2008 


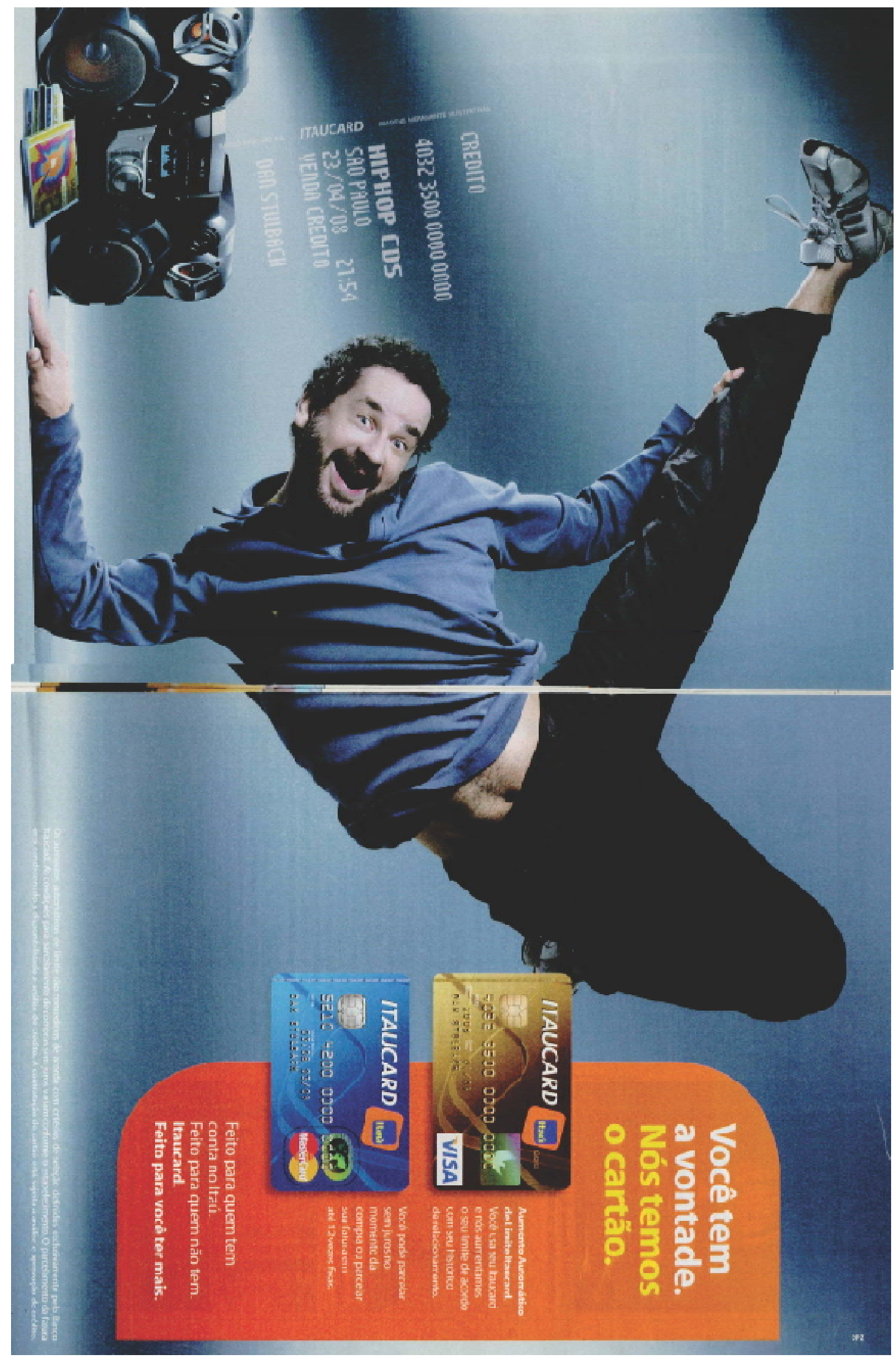

Propaganda 23 - Série "Bancos" - Revista Veja 14/05/2008 


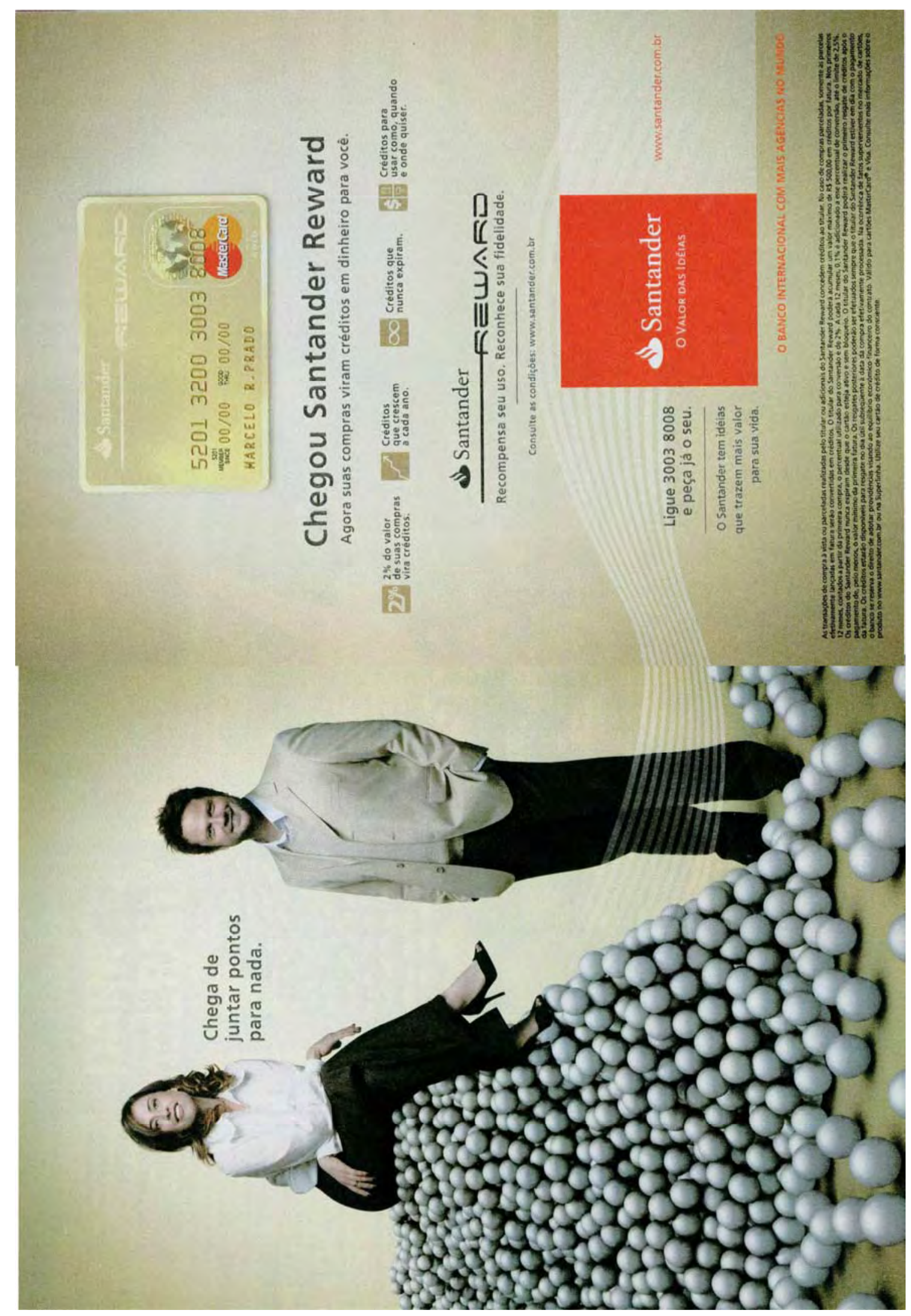

Propaganda 24 - Série "Bancos" - Revista Veja 16/07/2008 


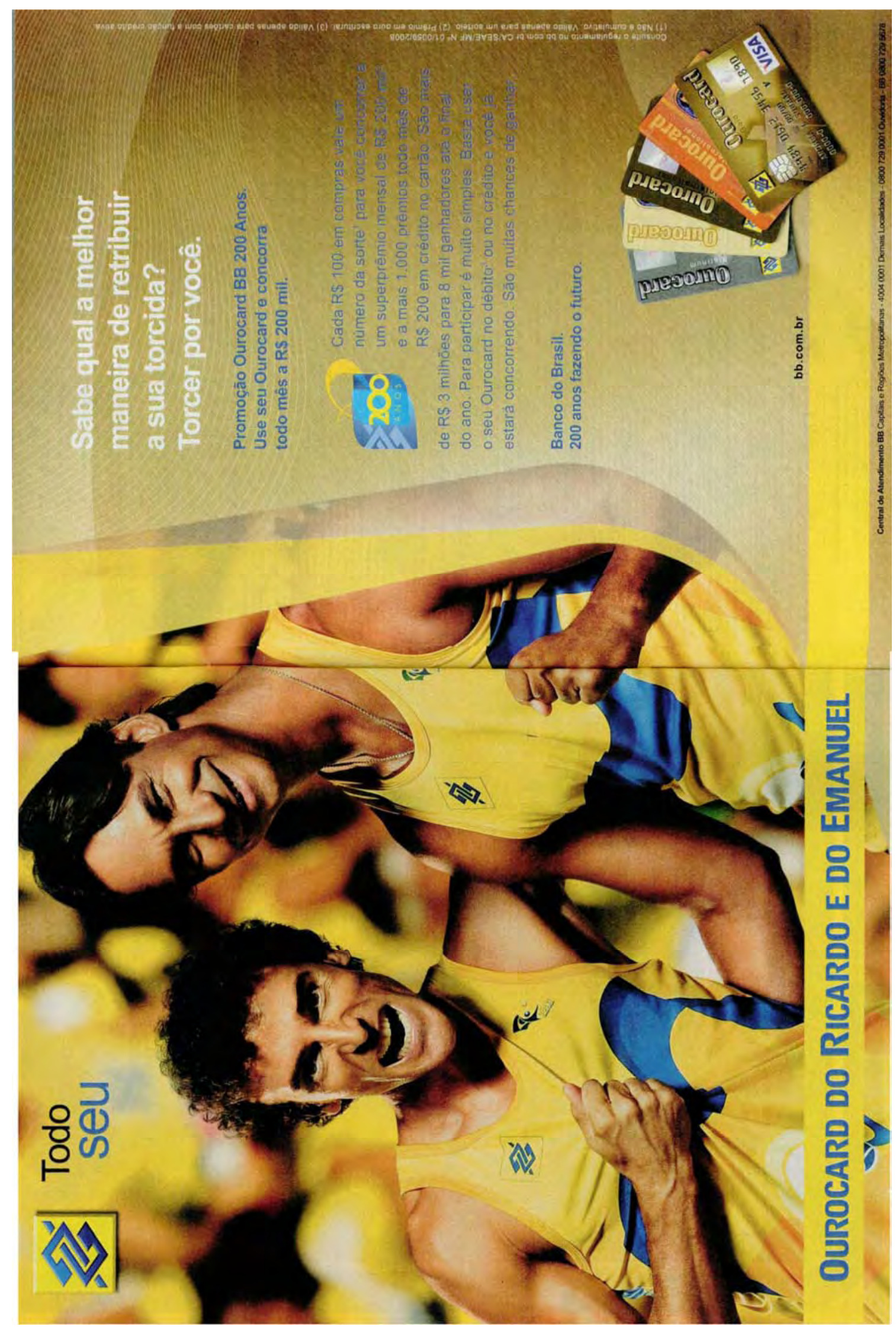

Propaganda 25 - Série "Bancos" - Revista Veja 21/05/2008 
Autorizo a reprodução deste trabalho.

São José do Rio Preto, 10 de Setembro de 2010.

WALKIRIA APARECIDA DAVID SILVA 
